Prepared in cooperation with the city of Needles, California

\title{
Initial Characterization of the Groundwater System near the Lower Colorado Water Supply Project, Imperial Valley, California
}

Scientific Investigations Report 2015-5102

U.S. Department of the Interior U.S. Geological Survey 
Cover. Photo of All-American Canal, Lower Colorado Water Supply Project discharge, and Algodones Dunes. Photo credit: Kimberly R. Beisner 


\section{Initial Characterization of the Groundwater System near the Lower Colorado Water Supply Project, Imperial Valley, California}

By Alissa L. Coes, Michael Land, Jill N. Densmore, Michael T. Landrum,

Kimberly R. Beisner, Jeffrey R. Kennedy, Jamie P. Macy, and Fred D. Tillman

Prepared in cooperation with the city of Needles, California

Scientific Investigations Report 2015-5102 


\title{
U.S. Department of the Interior SALLY JEWELL, Secretary
}

\section{U.S. Geological Survey \\ Suzette M. Kimball, Acting Director}

\author{
U.S. Geological Survey, Reston, Virginia: 2015
}

For more information on the USGS - the Federal source for science about the Earth, its natural and living resources, natural hazards, and the environment—visit http://www.usgs.gov or call 1-888-ASK-USGS.

For an overview of USGS information products, including maps, imagery, and publications, visit http://www.usgs.gov/pubprod/.

Any use of trade, firm, or product names is for descriptive purposes only and does not imply endorsement by the U.S. Government.

Although this information product, for the most part, is in the public domain, it also may contain copyrighted materials as noted in the text. Permission to reproduce copyrighted items must be secured from the copyright owner.

Suggested citation:

Coes, A.L., Land, Michael, Densmore, J.N., Landrum, M.T., Beisner, K.R., Kennedy, J.R., Macy, J.P., and Tillman, F.D., 2015, Initial characterization of the groundwater system near the Lower Colorado Water Supply Project, Imperial Valley, California: U.S. Geological Survey, Scientific Investigations Report Series 2015-5102, 59 p.

http://dx.doi.org/10.3133/sir20155102. 


\section{Contents}

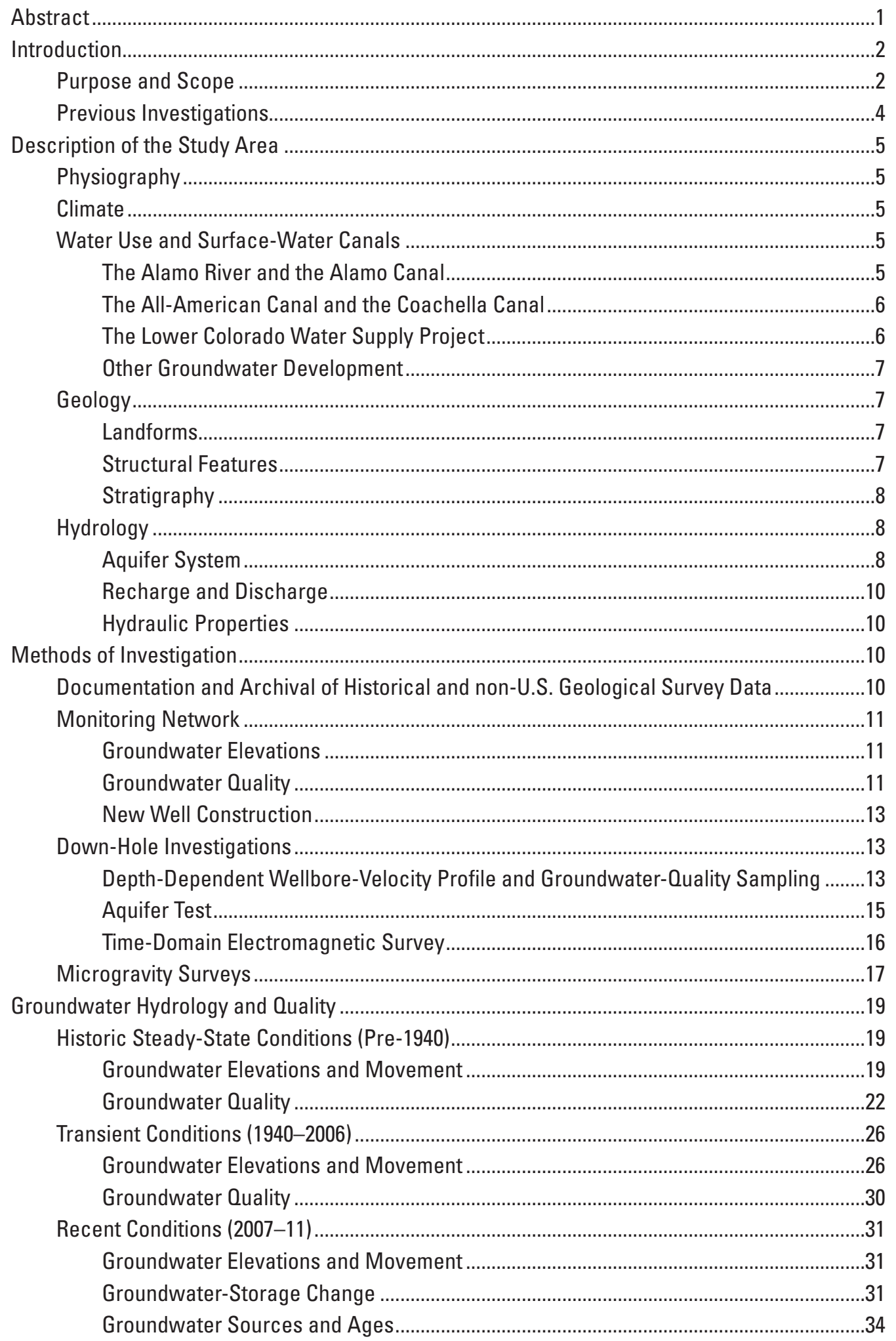




\section{Contents-Continued}

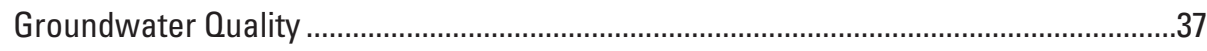

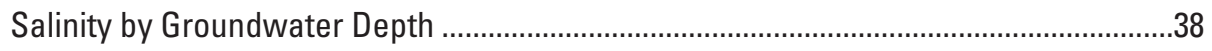

Lower Colorado Water Supply Project................................................................................4

Groundwater Elevations and Wellbore Flow..................................................................41

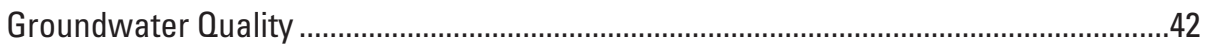

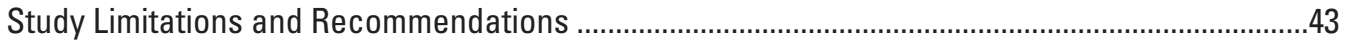

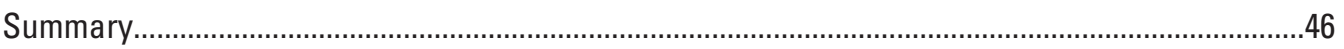

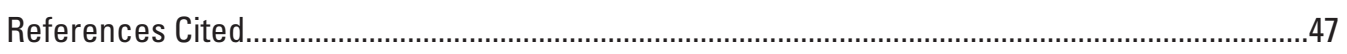

Appendix 1. Well Construction and Groundwater Elevation Data .................................................54

Appendix 2. Gravity Data, Methods, and Interpretation.............................................................55

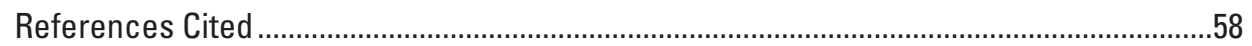

Appendix 3. Water-Quality Assurance Plan and Water-Quality Control Data...................................59

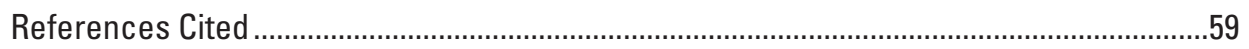

\section{Figures}

1. Map showing location of study area and important features, Imperial Valley, California

2. Images showing transect $\mathrm{A}-\mathrm{A}^{\prime}$ in the study area by the Lower Colorado Water Supply Project, Imperial Valley, California: $A$, aerial photograph with location of transect $\mathrm{A}-\mathrm{A}^{\prime} ; B$, cross section of stratigraphy along transect $\mathrm{A}-\mathrm{A}^{\prime}$.

3. Map showing location of the groundwater-elevation network wells, geographic areas, and transect B-B', Imperial Valley, California.

4. Map showing location of the groundwater-quality network wells and geographic areas, Imperial Valley, California

5. Figure showing natural gamma radiation and electromagnetic conductivity logs, well construction, and lithology of well NDL1, Imperial Valley, California.

6. Graph showing measured and modeled groundwater recovery and drawdown during an aquifer test, well LCWSP-2, Imperial Valley, California, August 18September 18, 2009.

7. Map showing location of transect $\mathrm{C}-\mathrm{C}^{\prime}$, the time-domain electromagnetic soundings (unfilled circles), and selected wells (filled circles) that includes borehole lithologic logs of AAC-12 Deep and Cactus Well, Imperial Valley, California

8. Map showing microgravity network (labelled in bold lettering) and monitoringwell (unfilled circles) locations, Imperial Valley, California.

9. Groundwater-elevation contours, in feet, and locations of measurements, Imperial Valley, California: $A, 1931-40 ; B, 1998-99$; $C$, November 2009; D, September 2011.

10. Map showing total-dissolved solids (TDS) concentrations, in milligrams per liter $(\mathrm{mg} / \mathrm{L})$ in groundwater and locations of measurements, Imperial Valley, California: A, 1917-41; B, 1961-65; C, 2007-11.

11. Piper diagrams showing groundwater quality, Imperial Valley, California: $A, 1917-41$;

$B, 1961-65 ; C$, 2007-11. TDS, total dissolved solids; $\mathrm{mg} / \mathrm{L}$, milligrams per liter 


\section{Figures-Continued}

12. Hydrographs showing groundwater elevations in selected wells, 1960-2011, Imperial Valley, California: $A$, near the All-American Canal; $B$, on the East Mesa; $C$, on the Pilot Knob Mesa and in the Algodones Dunes. LCWSP, Lower Colorado Water Supply Project; AAC, All-American Canal.....

13. Maps showing groundwater-elevation change, in feet, Imperial Valley, California: A, from 1931-40 to 1998-99; $B$, from 1998-99 to September 2011.

14. Cross-section graphs showing groundwater-elevation change along the All-American Canal, Imperial Valley, California: $A$, 1931-2005; $B$, 2005-11.

15. Hydrograph showing continuous groundwater elevations in selected wells and surface-water discharge in the All-American Canal downstream from Pilot Knob Wasteway, Imperial Valley, California, 2001-11.

16. Hydrographs showing groundwater elevations in selected wells, Imperial Valley, California: $A$, near the the All-American Canal, 2006-11; B, on the East Mesa, 2009$11 ; C$, on the Pilot Knob Mesa and in the Algodones Dunes, 2007-11 .

17. Graphs showing gravity change and groundwater-elevation change, 2009-11, Imperial Valley, California: $A$, transect $1 ; B$, transect 2; $C$, transect 3; $D$, transect 4; E, PK-1 and AAC-17

18. Graph showing delta hydrogen-2/hydrogen-1 and delta oxygen-18/oxygen-16 in groundwater, Imperial Valley, California, 2007-11.

19. Map showing delta oxygen-18/oxygen-16 in groundwater sampled from wells, Imperial Valley, California, 2007-11

20. Map showing tritium and carbon-14 in groundwater, Imperial Valley, California, 2007-11

21. Graph showing total dissolved solids concentration by time in groundwater from selected wells and surface water in the Colorado River upstream from Imperial Dam, Imperial Valley, California, 2009-11

22. Graphs showing lithologic logs, time-domain electromagnetic (TEM) onedimensional (1-D) models, and cross-section of subsurface resistivity along transect $\mathrm{C}-C^{\prime}$, Imperial Valley, California: $A$, well AAC-12 Deep and soundings 1-7; $B$, soundings $8-23 ; C$, Cactus well and soundings $24-26$.

23. Graph showing total-dissolved-solids concentrations and groundwater elevation, 1990-2011, in well LCWSP-2 and total-dissolved-solids concentrations in surface water in the Colorado River upstream from Imperial Dam, Imperial Valley, California

24. Graph showing wellbore-velocity profile and lithology in well LCWSP-2 at Lower Colorado Water Supply Project, Imperial Valley, California, August 2009

25. Piper diagrams showing groundwater quality in the vicinity of the Lower Colorado Water Supply Project, Imperial Valley, California, 1941 and 2009-11

26. Piper diagram showing groundwater quality from various depths below land surface (BLS) in well LCWSP-2, Imperial Valley, California, August 2009

27. Graph showing delta hydrogen-2/hydrogen-1 and delta oxygen-18/oxygen-16 in groundwater from various depths below land surface (BLS) in well LCWSP-2, Imperial Valley, California, August 2009.

2-1. Complete Bouguer gravity anomaly showing gravity measurement sites, and location of cross section D-D', Imperial Valley, California.

2-2. Cross sections showing: $A$, measured and predicted gravity anomaly along transect D-D; $B$, subsurface density model along transect D-D', Imperial Valley, California 


\section{Tables}

1. Daily mean discharge and gage height in the All American Canal below Pilot Knob Wasteway (station 09527500) during gravity measurements.

2. Correlation of microgravity change and groundwater-elevation change, and resulting estimates of specific yield.....

1-1. Groundwater-elevation network well data and groundwater-elevation data, Imperial Valley, California, 2009-11

1-2. Groundwater-quality network well data and groundwater-quality and isotope data, Imperial Valley, California, 2007-11

1-3. Composite and depth-specific groundwater-quality and isotope data for well LCWSP-2, Imperial Valley, California, August 26-27, 2009.

1-4. Gravity in microgals ( $\mu$ gal) at gravity stations, Imperial Valley, California, 2009-11 .......54

1-5. Repeat land-surface elevation- measurements at gravity stations, Imperial Valley, California, 2009-10.

\section{Abbreviated Water-Quality and Isotopic Units}

Temperatures are given in degrees Celsius $\left({ }^{\circ} \mathrm{C}\right)$, which may be converted to degrees Fahrenheit $\left({ }^{\circ} \mathrm{F}\right)$ by using the following equation:

${ }^{\circ} \mathrm{F}=1.8\left({ }^{\circ} \mathrm{C}\right)+32$

Chemical concentrations are given in metric units. Chemical concentration in water is given in milligrams per liter (mg/L) or micrograms per liter ( $\mu \mathrm{g} / \mathrm{L})$. Milligrams per liter is a unit expressing the solute per unit volume (liter) of water. One thousand micrograms per liter is equivalent to 1 milligram per liter. For concentrations less than 7,000 milligrams per liter, the numerical value is about the same as for concentrations in parts per million.

Specific conductance is given in microsiemens per centimeter $(\mu \mathrm{S} / \mathrm{cm})$ at $25^{\circ} \mathrm{C}$. Microsiemens per centimeter at $25^{\circ} \mathrm{C}$ is a unit expressing the amount of electrical conductivity of a solution as measured between opposite faces of a centimeter cube of solution at a specified temperature of $25^{\circ} \mathrm{C}$.

The relative abundance of stable isotopes of hydrogen $\left({ }^{2} \mathrm{H} /{ }^{1} \mathrm{H}\right)$ and oxygen $\left({ }^{18} \mathrm{O} /{ }^{16} \mathrm{O}\right)$ in water are reported relative to the Vienna Standard Mean Ocean Water (VSMOW) that is prepared and distributed by the International Atomic Energy Agency. Values are reported in per mil units $(\%)$ using delta $(\delta)$ notation. The radioactive isotope of hydrogen (tritium, ${ }^{3} \mathrm{H}$ ) is reported in tritium units (TU). One tritium unit is equal to one molecule of ${ }^{3} \mathrm{H}$ per $10^{18}$ molecules of ${ }^{2} \mathrm{H}$ and has an activity of 3.19 picoCuries per liter $(\mathrm{pCi} / \mathrm{L})$ of water. The radioactive isotope of carbon $\left({ }^{14} \mathrm{C}\right)$ is reported in percent modern carbon $(\mathrm{pmC})$. Percent modern carbon represents the proportion of the ${ }^{14} \mathrm{C}$ atoms present in the water at the time of sampling compared to the proportion of the ${ }^{14} \mathrm{C}$ atoms present in the water in the year 1950. 


\section{Vertical and Horizontal Datums}

Vertical coordinate information is referenced to the North American Vertical Datum of 1988 (NAVD88). Elevation, as used in this report, refers to distance above or below the vertical datum.

Horizontal coordinate information is referenced to the North American Datum of 1983 (NAD83).

\section{Abbreviated Geophysical Terms}

Geophysical terms are given in the metric units. Gravity measurements are given in milligal ( $\mathrm{mGal}$ ) or microgal $(\mu \mathrm{Gal})$. Milligal is defined as $10^{-3}$ centimeter per second squared and is equal to an acceleration of $3.281 \times 10^{-5} \mathrm{ft}$ per second squared. One-thousand microgal is equivalent to 1 milligal. Density measurements are given in gram per cubic centimeter $\left(\mathrm{g} / \mathrm{cm}^{3}\right)$, which is equal to 62.43 pounds per cubic foot $\left(\mathrm{lb} / \mathrm{ft}^{3}\right)$. Resistivity measurements are given in ohm-meters (ohm-m) which is defined as the electrical resistance of a conductor (in ohms) multiplied by the conductor's cross-sectional area and divided by the conductor's length.

\section{Abbreviations}

$\begin{array}{ll}\text { AAC } & \text { All-American Canal } \\ \text { bls } & \text { below land surface } \\ \text { CVWD } & \text { Coachella Valley Water District } \\ \text { GAMA } & \text { Groundwater Ambient Monitoring and Assessment } \\ \text { GPS } & \text { Global Positioning System } \\ \text { IID } & \text { Imperial Irrigation District } \\ \text { LCWSP } & \text { Lower Colorado Water Supply Project } \\ \text { msec } & \text { millisecond } \\ \text { NWIS } & \text { National Water Information System (USGS) } \\ \text { NWOL } & \text { National Water Quality Laboratory (USGS) } \\ \text { PST } & \text { Pacific Standard Time } \\ \text { PVC } & \text { polyvinyl chloride } \\ \text { TEM } & \text { Time-Domain Electromagnetic } \\ \text { TDS } & \text { total dissolved solids } \\ \text { USGS } & \text { U.S. Geological Survey }\end{array}$




\section{Conversion Factors}

Inch/Pound to International System of Units

\begin{tabular}{|c|c|c|}
\hline Multiply & By & To obtain \\
\hline \multicolumn{3}{|c|}{ Length } \\
\hline inch (in.) & 2.54 & centimeter $(\mathrm{cm})$ \\
\hline inch (in.) & 25.4 & millimeter (mm) \\
\hline foot $(\mathrm{ft})$ & 0.3048 & meter (m) \\
\hline mile (mi) & 1.609 & kilometer $(\mathrm{km})$ \\
\hline \multicolumn{3}{|c|}{ Area } \\
\hline square mile $\left(\mathrm{mi}^{2}\right)$ & 259.0 & hectare (ha) \\
\hline square mile $\left(\mathrm{mi}^{2}\right)$ & 2.590 & square kilometer $\left(\mathrm{km}^{2}\right)$ \\
\hline \multicolumn{3}{|c|}{ Volume } \\
\hline acre-foot (acre-ft) & 1,233 & cubic meter $\left(\mathrm{m}^{3}\right)$ \\
\hline acre-foot (acre-ft) & 0.001233 & cubic hectometer $\left(\mathrm{hm}^{3}\right)$ \\
\hline \multicolumn{3}{|c|}{ Flow rate } \\
\hline acre-foot per day (acre-ft/d) & 0.01427 & cubic meter per second $\left(\mathrm{m}^{3} / \mathrm{s}\right)$ \\
\hline acre-foot per year (acre-ft/yr) & 1,233 & cubic meter per year (m³/yr) \\
\hline foot per year (ft/yr) & 0.3048 & meter per year (m/yr) \\
\hline cubic foot per second $\left(\mathrm{ft}^{3} / \mathrm{s}\right)$ & 0.02832 & cubic meter per second $\left(\mathrm{m}^{3} / \mathrm{s}\right)$ \\
\hline gallon per minute (gal/min) & 0.06309 & liter per second $(\mathrm{L} / \mathrm{s})$ \\
\hline inch per day (in/d) & 293.982 & nanometers per second $(\mathrm{nm} / \mathrm{s})$ \\
\hline \multicolumn{3}{|c|}{ Density } \\
\hline pound per cubic foot $\left(\mathrm{lb} / \mathrm{ft}^{3}\right)$ & 16.02 & kilogram per cubic meter $\left(\mathrm{kg} / \mathrm{m}^{3}\right)$ \\
\hline \multicolumn{3}{|c|}{ Specific capacity } \\
\hline gallon per minute per foot [(gal/min $) / \mathrm{ft})]$ & 0.2070 & liter per second per meter $[(\mathrm{L} / \mathrm{s}) / \mathrm{m}]$ \\
\hline
\end{tabular}

\section{Acknowledgments}

Lawrence Bell, of the Parsons Corporation, provided invaluable guidance early in the study with access to the All-American Canal during lining, contacts involved with the All-American Canal lining, and safety issues related to working along the All-American Canal during lining. Historical well and groundwater data were provided by the U.S. Bureau of Reclamation; Imperial Irrigation District; Geotechnics, Incorporated; Kiewit Pacific Corporation; Ames Coffman Specialties Joint Venture; and Axiom-Blair Engineering. 


\title{
Initial Characterization of the Groundwater System near the Lower Colorado Water Supply Project, Imperial Valley, California
}

\author{
By Alissa L. Coes, Michael Land, Jill N. Densmore, Michael T. Landrum, Kimberly R. Beisner, \\ Jeffrey R. Kennedy, Jamie P. Macy, and Fred D. Tillman
}

\section{Abstract}

In 2009, the U.S. Geological Survey, in cooperation with the city of Needles, began a study of the hydrogeology along the All-American Canal, which conveys water from the Colorado River to the Imperial Valley. The focus of this study was to gain a better understanding of the effect of lining the All-American Canal, and other management actions, on future total dissolved solids concentrations in groundwater pumped by Lower Colorado Water Supply Project wells that is delivered to the All-American Canal. The study included the compilation and evaluation of previously published hydrogeologic and geochemical information, establishment of a groundwater-elevation and groundwater-quality monitoring network, results of monitoring groundwater elevations and groundwater quality from 2009 to 2011 , site-specific hydrologic investigations of the Lower Colorado Water Supply Project area, examination of groundwater salinity by depth by using time-domain electromagnetic surveys, and monitoring of groundwater-storage change by using microgravity methods.

Prior to the completion of the All-American Canal in 1940, groundwater in the study area flowed from east to west, and groundwater was recharged primarily by underflow from the Colorado River Valley. After construction of the All-American Canal, groundwater elevations were altered in the study area as seepage of Colorado River water from the All-American Canal and other canals became the dominant recharge source. By 2005, groundwater elevations had increased by as much as 50-70 feet along the All-American Canal. Superimposed on the east-to-west groundwater gradient was groundwater movement away from the All-American Canal to the north and, most likely, to the south into Mexico. After lining the All-American Canal, from 2007 to 2010, groundwater elevations declined as seepage from the AllAmerican Canal decreased. Between 2005 (the last complete groundwater-elevation survey prior to lining the All-American Canal) and 2011, groundwater elevations declined 20-40 feet along the All-American Canal and as much as $40-45$ feet in the vicinity of Lower Colorado Water Supply Project pumping wells.
Water-quality and isotope data were used to differentiate historically recharged groundwater from groundwater more recently recharged by seepage of Colorado River surface water from the All-American Canal. Prior to the completion of the All-American Canal in 1940, groundwater in the southern part of the study area was primarily sodium-chloride/sulfate type water that had relatively low total dissolved solids concentrations (500-820 milligrams per liter). During 200711 , groundwater in the southern part of the study area, near the All-American Canal, ranged from sodium-chloride type water to mixed-cation-sulfate type water that had total dissolved solids concentrations generally less than 879 milligrams per liter. The stable-isotopic signature of groundwater near the All-American Canal sampled in 2009-11 indicated inputs of Colorado River water that had been affected by evaporation, and radioactive isotopes indicated that a substantial fraction of water had been recharged recently, within the past 60 years. This contrasted with historically recharged groundwater near the All-American Canal, which had higher sodium and chloride concentrations, and lower calcium and sulfate concentrations, than recent recharge from the All-American Canal.

Groundwater at a distance from the All-American Canal, in the East Mesa, Algodones Dunes, Pilot Knob Mesa, and Cargo Muchacho Mountains piedmont, was found to have higher total dissolved solids concentrations (generally greater than 1,000 milligrams per liter) than recently recharged groundwater near the All-American Canal. Time-domain electromagnetic data indicated that low-salinity groundwater was present down to about 377 feet below land surface near the All-American Canal; groundwater salinity at depth increased with distance north from the All-American Canal. Groundwater several miles or more from the canal also did not contain tritium and had a residence time on the order of thousands to tens of thousands of years. The groundwater in the piedmont of the Cargo Muchacho Mountains had a distinctly light stable-isotopic signature indicative of recharge by runoff from local precipitation, whereas the stable isotopic signature of groundwater in the East Mesa and the Algodones Dunes indicated a mixture of local precipitation and historic Colorado River recharge sources. 
During and after lining the All-American Canal (2007-11), groundwater elevations in the Lower Colorado Water Supply Project area declined, while total dissolved solids concentrations remained relatively constant. The total dissolved solids concentrations in well LCWSP-2 ranged from 650 to 800 milligrams per liter during this study. Depthspecific water-quality and isotope sampling at well LCWSP-2 indicated the groundwater pumped from the deeper part of the screened interval (240-280 feet below land surface) contained a greater proportion of historical groundwater than the groundwater pumped from the shallower part of the screened interval (350-385 feet below land surface). Agetracer data at well LCWSP-2 indicated that all depths of the screened interval had received recent recharge from seepage of Colorado River water from the All-American Canal.

\section{Introduction}

In 1940, construction of the 82-mile (mi) All-American Canal (AAC) through southern California (fig. 1) was completed to bring Colorado River water to cities and agricultural fields in the Imperial Valley. From 1942 to 2006, leakage from the unlined AAC was a major source of recharge to the underlying aquifer system, which resulted in rises in groundwater elevations along the AAC (U.S. Bureau of Reclamation, 1994). In 2010, the AAC was lined with concrete along a 22.3-mi section from Pilot Knob to Drop 3, which conserved an estimated 67,700 acre-feet (acre-ft) of water in the AAC per year and reduced recharge to the aquifer by the same amount (U.S. Bureau of Reclamation, 1994).

In 1986, the U.S. Bureau of Reclamation (Reclamation) received authorization to construct, operate, and maintain well-field facilities in the Algodones Dunes area along the AAC in Imperial County, California, as part of the Lower Colorado Water Supply Project (LCWSP; fig. 1). Since 1996, groundwater from LCWSP wells has supplied up to 10,000 acre-ft per year (acre-ft/yr) of water to non-agricultural California users who do not hold rights to Colorado River water or whose rights are insufficient to meet their present or anticipated future needs. An acceptable limit for the salinity of water delivered to the Imperial Irrigation District (IID) and Coachella Valley Water District (CVWD) through the AAC from the LCWSP well field was set at 879 milligrams per liter (mg/L), plus or minus $30 \mathrm{mg} / \mathrm{L}$, on an average annual flowweighted basis (U.S. Bureau of Reclamation, 2004).
In 2009, the U.S. Geological Survey (USGS) entered an agreement with the city of Needles to investigate the hydrogeology of the area around the LCWSP well field, with a focus on understanding the effect of lining the AAC, and other management actions, on future total dissolved solids (TDS) concentrations in groundwater delivered to the AAC from LCWSP wells. In cooperation with the city of Needles, the USGS identified three phases of work to inform forecasts of TDS concentrations in water from LCWSP wells:

- Phase 1. Establishment of a monitoring network and an initial characterization of the aquifer system in the study area.

- Phase 2. Comprehensive investigation of the groundwater system in the study area and its relation to the LCWSP.

- Phase 3. Development and application of a numerical groundwater model to estimate future TDS concentrations in groundwater pumped from LCWSP wells.

This report presents results for Phase 1, which addressed the following objectives:

1. Summarize the current knowledge of the groundwater system in the LCWSP study area on the basis of historic data.

2. Determine data and information needs.

3. Establish a hydrologic monitoring network.

4. Provide an initial characterization of the groundwater system in the area based on historic and newly collected data.

\section{Purpose and Scope}

The purpose of this report is to present a synthesis and interpretation of new and existing hydrologic, geologic, and geochemical data from the study area in the southeastern corner of California (fig. 1). The scope of the report includes (1) an evaluation and compilation of hydrogeologic and geochemical information from available sources, (2) establishment of a water-elevation and waterquality monitoring network, (3) results from monitoring groundwater elevations and quality from 2009 to 2011, (4) site-specific investigations of the LCWSP area, (5) surfacegeophysical investigations of salinity by using time-domain electromagnetic (TEM), and (6) monitoring of aquifer-storage change by using microgravity methods. 
Water Supply Project well field

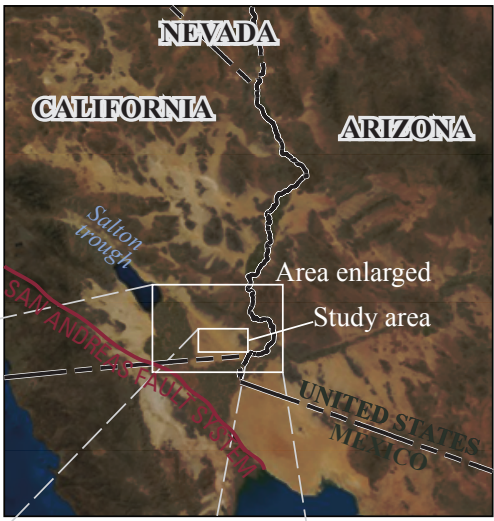

$115^{\circ} 30^{\prime}$

$115^{\circ} 0^{\prime}$

$114^{\circ} 30^{\prime}$

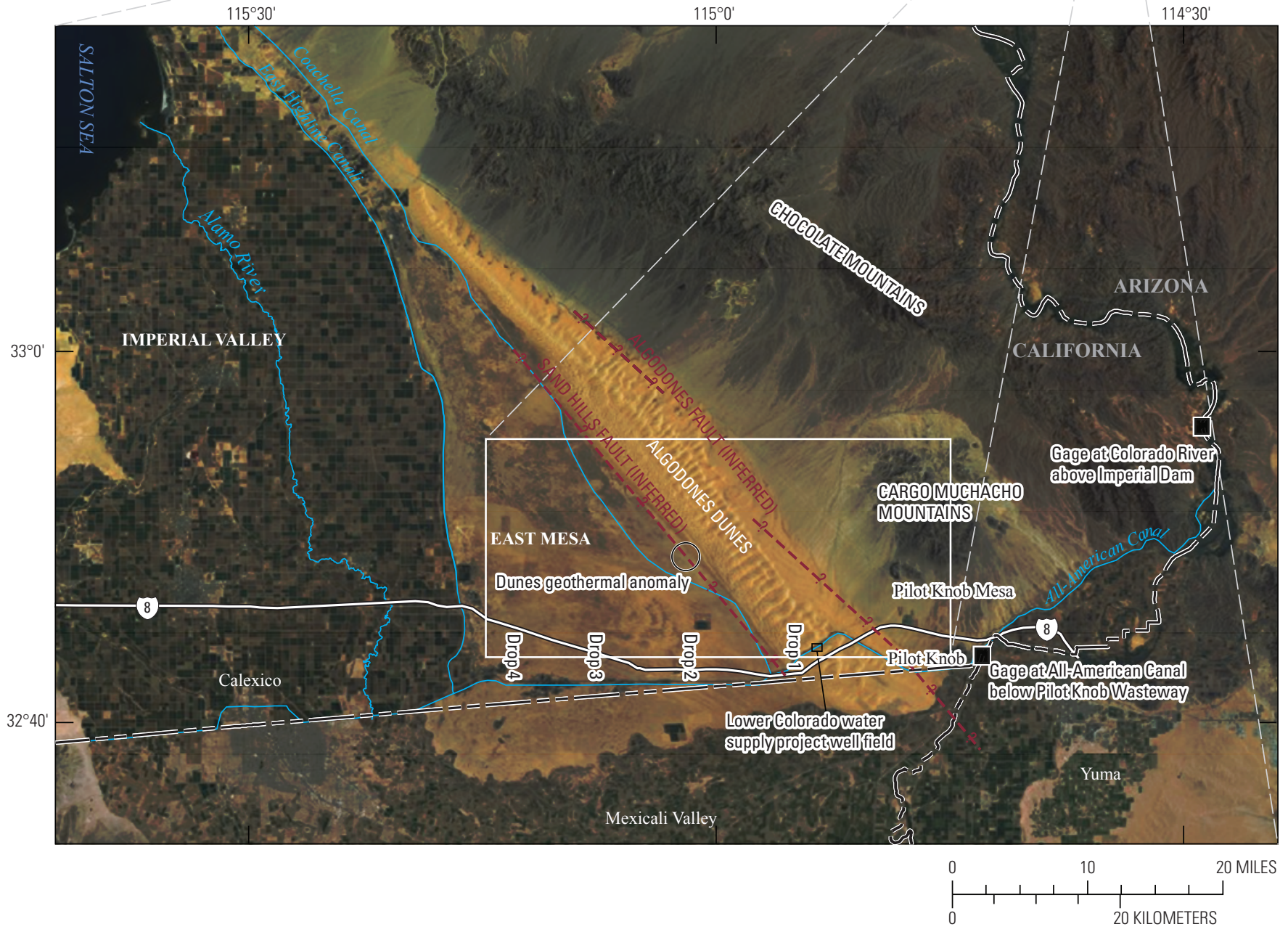

Figure 1. Location of study area and important features, Imperial Valley, California. 
Initial Characterization of the Groundwater System near the Lower Colorado Water Supply Project, Imperial Valley, Calif.

\section{Previous Investigations}

Numerous geologic and hydrologic investigations have been completed in the region around the recently lined section of the AAC. Owing to the proximity of the study area to the tectonically active San Andreas fault system, important geothermal resources, the Colorado River and Salton Trough, the prehistoric Lake Cahuilla in the Imperial Valley, and the Algodones Dunes, the geology of the region has been studied over several decades. Regional slip-strike faults, including the San Andreas, Imperial, Sand Hills, and Algodones faults, along with extensional faulting and crustal spreading in the area, have been the subject of numerous studies (Hamilton, 1961; Biehler and others, 1964; Elders and others, 1972; Hill and others, 1975; Fuis and Kohler, 1984; Wallace, 1990; DeMets, 1995; Parsons and McCarthy, 1996; Axen and Fletcher, 1998; Dorsey, 2006). Several investigators have studied the bedrock depth and structure (Kovach and others, 1962; Fuis and others, 1984; Kohler and Fuis, 1986; Chávez and others, 1999).

Several geologic studies assessed the potential for geothermal development in the Imperial Valley geothermal area (Rex and others, 1971; Hill and others, 1975; Fuis and others, 1984) and in the nearby Cerro Prieto geothermal field in Mexico (Elders and others, 1984; Halfman and others, 1984; Lippmann and others, 1991; Elders and others, 1997). Other studies have focused on the shifting course of the ancestral Colorado River and the location of associated river delta deposits in the Salton Trough (Merriam and Bandy, 1965; Muffler and Doe, 1968; Van de Kamp, 1973; Meckel, 1975; Jennings and Thompson, 1986; Winker and Kidwell, 1986; Pacheco and others, 2006). Several paleohydrologic studies in the area investigated the prehistoric Lake Cahuilla (Blake, 1907; Waters, 1983; Buckles and others, 2002) and the origin, formation, movement, and mineral resources of sand in the Algodones Dunes area (Norris and Norris, 1961; McCoy and others, 1967; Merriam, 1969; Van de Kamp, 1973; Sharp, 1979; Smith and others, 1984; Nielson and Kocurek, 1986; Havholm and Kocurek, 1988; Sweet and others, 1988; Winspear and Pye, 1995; Stokes and others, 1997; Derickson and others, 2008).

Early hydrologic studies in the vicinity of the study area focused on the channel breech of the Colorado River in 1905 and the redirection of its flow to the northwest, forming the modern Salton Sea (Day, 1906; James, 1906; Grunsky, 1907). Regional reconnaissance studies for water in the area were first published by the USGS (Mendenhall, 1909a, 1909b). Groundwater level and groundwater-quality data collected from wells in the area were presented by Brown (1923) in a USGS report describing the geology, mineral resources, hydrology, and "suggestions to travelers" about where to find "desert watering places" along common routes through the area. Hydrogeologic and groundwater-quality investigations were done because of the proximity of the study area to geothermal resources (Dutcher and others, 1972; Mediav and Furgerson, 1972; Hardt and French, 1976) and important agricultural areas in the Colorado River Delta region in the U.S. and Mexico (Loeltz and others, 1975; Harshbarger, 1977). Several additional USGS studies of water resources in the lower Colorado River and Salton Sea area were completed during the late 1960s and early 1970s (Hely and Peck, 1964; Hely and others, 1966; McDonald and Hughes, 1968; Hely, 1969; Irelan, 1971; Metzger and Loeltz, 1973; Metzger and others, 1973; Olmstead and others, 1973; McDonald and Loeltz, 1976; Patten, 1977). Loeltz and others (1975) described the geologic and hydrologic setting of the area, detailing sources of groundwater recharge and providing groundwater levels, groundwater quality, and drillers' logs from selected wells.

In response to the 1964 U.S. Supreme Court decision mandating an account of the use of Colorado River water, an accounting method was developed for the area to identify wells that yielded water that would be replaced by water from the river (Wilson and Owen-Joyce, 1994; Owen-Joyce and others, 2000). Other studies have used geochemistry and isotopic methods to investigate the origin of groundwater in the lower Colorado River Valley in the U.S. and Mexico (Payne and others, 1979; Smith and others, 1992; Gleason and others, 1994; Portugal and others, 2005; Guay and others, 2006). Numerical groundwater-flow models have been developed to simulate the potential effects on groundwater resources from lining the Coachella and All-American Canals (Loeltz and Leake, 1979), to investigate regional water management of groundwater and surface water in Imperial County (Montgomery Watson, 1996), to investigate regional groundwater availability in the Salton Sea Basin (Tompson and others, 2008), and to investigate the groundwater system in the Colorado River Delta in Mexico (Feirstein and others, 2008).

Hydrologic effects from the AAC have been assessed by environmental impact reports (U.S. Bureau of Reclamation, 1994, 2006; Watt, 1994), geotechnical investigations

(Geotechnics Inc., 2005), and construction dewatering studies (Axiom-Blair Engineering, 2006) related to the lining project; by a feasibility study of recovering groundwater near the canal (LeRoy Crandall and Associates, 1983); and by studies of canal seepage and inflows to nearby wetlands and the Salton Sea (Tetra Tech Inc., 1999). Projected effects from lining the AAC on groundwater resources in Mexico also were detailed in several investigations (National Water Commission of Mexico, 1991, 2005; Hinojosa-Huerta and others, 2002; Castro-Ruiz and Sánchez-Munguia, 2005; Maganda, 2005; and Ganster, 2006). 


\section{Description of the Study Area}

The study area covers over 1,000 square miles $\left(\mathrm{mi}^{2}\right)$, mostly in the Salton Trough section of the Basin and Range physiographic province in the Intermountain Plateau division of southeastern California (fig. 1; Fenneman, 1931; Fenneman and Johnson, 1946). Boundaries of the study area extended approximately $56 \mathrm{mi}$ from the Alamo River east to the Colorado River, and approximately $20 \mathrm{mi}$ from the 33rd north parallel to the U.S.-Mexico border.

\section{Physiography}

Prominent surficial features in the study area include the southern end of the Chocolate Mountains, the Cargo Muchacho Mountains, and Pilot Knob in the east; agricultural fields in Imperial Valley in the west; and the Algodones Dunes running northwest to southeast through the middle of the study area, separating East Mesa to the west and Pilot Knob Mesa to the east (fig. 1). Land-surface elevations range from a low of -150 feet (ft; North American Vertical Datum of 1988) in the northwest, in the Imperial Valley agricultural area, to a high of 2,220 ft in the Cargo Muchacho Mountains. The highest elevation of the Chocolate Mountains in the study area is $1,480 \mathrm{ft}$, and Pilot Knob reaches $880 \mathrm{ft}$. Dunes in the Algodones Sand Hills are generally taller in the northern portion of the study area, rising $300 \mathrm{ft}$ or more in height.

The AAC traverses the study area for $62 \mathrm{mi}$, flowing southwest from its inception at the Imperial Dam on the Colorado River toward Pilot Knob; northwest, then southwest, through the Algodones Dunes; then generally westward along the United States-Mexico border (fig. 1). The Coachella Canal originates just west of the Algodones Dunes at Drop 1 and transports water from the AAC northwest along the East Mesa to the CVWD. Concrete lining of the AAC was completed in 2010 on a 23-mi section from Pilot Knob to Drop 3.

\section{Climate}

The study area lies in one of the hottest and driest regions of the United States. Maximum annual temperatures in the study area averaged 31 degrees Celsius $\left({ }^{\circ} \mathrm{C}\right)$ during 1940-2011 (PRISM Group, 2010), and minimum annual temperatures averaged $15^{\circ} \mathrm{C}$. The hottest months of the year are July and August, having average maximum temperatures of $42{ }^{\circ} \mathrm{C}$ and $41^{\circ} \mathrm{C}$, respectively, during 1940-2011 (PRISM Group, 2010). The coolest months of the year are December, January, and February, when monthly average minimum temperatures are around $6{ }^{\circ} \mathrm{C}$ (PRISM Group, 2010). Although varying from year to year, precipitation in the study area is minimal, having an annual average of 3 inches (in.) during 1940-2011. The greatest proportion of the annual precipitation falls in December, January, and August, averaging 0.4 in. during each of these months.

\section{Water Use and Surface-Water Canals}

\section{The Alamo River and the Alamo Canal}

The modern history of water use in the area began in the mid-19th century. The Gold Rush of 1849 brought Dr. Oliver Wozencraft across the Sonoran Desert, where he noted that the valley could be irrigated by diverting the Colorado River through the Alamo River (Woerner, 1989). The Alamo River was a dry overflow channel that crossed the border into Mexico near Calexico, California, and then turned eastward toward the Colorado River. Around the same time, William Phipps Blake, on a reconnaissance expedition to survey routes for a railroad, noted that the extremely rich, fluvial soils in the Salton Sink area deposited by flooding of the Colorado River would likely produce bountiful crops, if sufficient irrigation was applied (Blake, 1854). Blake, however, had doubts about irrigation projects in the area dependent on the Colorado River because of the potential for catastrophic flooding of the belowsea-level valley should there be problems controlling the canal or river (Woerner, 1989). The idea of promoting agriculture in the Salton Sea area by irrigating with Colorado River water was taken up by Charles Rockwood and George Chaffey (who first used the term "Imperial Valley") in 1896 (Woerner, 1989). The Alamo River channel was chosen to convey the water because it provided a route around the Algodones Dunes. To connect the Colorado and Alamo Rivers, construction of the short Alamo Canal and of headgates to the canal near Yuma, Arizona, on the U.S. side of the international border, commenced in August 1900 (Woerner, 1989). Colorado River water first arrived in the Imperial Valley in June 1901, and by 1904, an estimated 150,000 acres were being irrigated (Woerner, 1989). In September 1904, the California Development Company decided to build a temporary intake to improve water delivery and meet rapidly growing demand for irrigation water in the Imperial Valley. The new intake was dug in Mexico about 4 miles south of the original intake and consisted of a trench $50 \mathrm{ft}$ wide and $6 \mathrm{ft}$ deep, with no headgate (Woerner, 1989). Floods on Colorado River tributaries in 1904-05 caused water levels on the Colorado River to rise, and, without a headgate, the new intake was unable to control the volume of water flowing down the Alamo Canal. By October 1905, the intake had grown to $600 \mathrm{ft}$ wide, and excess water reaching Imperial Valley began accumulating in the Salton Sink, rising at the rate of about 0.5 inch per day (Woerner, 1989). Eventually, nearly all the water in the Colorado River was flowing through the Alamo Canal and the Alamo River to the Salton Sea, which grew to a 10-mi-wide lake, stretching $40 \mathrm{mi}$ north-to-south, rising at a rate of 2-inches per day (Woerner, 1989). After several attempts at redirecting the flow of the Colorado River back to the Gulf of California, a dam was successfully constructed in 1907 (Woerner, 1989). 
Initial Characterization of the Groundwater System near the Lower Colorado Water Supply Project, Imperial Valley, Calif.

\section{The All-American Canal and the Coachella Canal}

These incidents, and the dependence of Alamo Canal operations on Mexican policy changes, led agricultural interests in the Imperial Valley to advocate for construction of an "All-American Canal" north of the U.S.-Mexico border (Castro-Ruiz and Sánchez-Munguia, 2005). The AAC was authorized by the U.S. Congress in the Boulder Canyon Project Act (1928). Construction of the AAC began in August 1934 and was completed in 1940. Water began flowing to the AAC in October 1940, and by February 1942, the AAC became the sole provider of Colorado River water to the Imperial Valley (LeRoy Crandall and Associates, 1983). The gravity-fed, unlined canal stretched $80 \mathrm{mi}$ from Imperial Dam to the Westside Canal, just west of Calexico, California, and had an average bottom width of $160 \mathrm{ft}$ and an average water depth of $21 \mathrm{ft}$ on the most upstream reach. The diversion capacity was 30,000 acre-ft per day (acre-ft/d) from Imperial Dam to Siphon Drop, 26,000 acre-ft/d from Siphon Drop to Pilot Knob, 20,000 acre-ft/d from Pilot Knob to Drop 1, and gradually reduced from 15,000 to 5,000 acre-ft/d from Drop 1 to the Westside Canal (U.S. Bureau of Reclamation, 2012). Power was generated at Drops $1-5$ and, also, at the East Highline Canal turnout for use by the Imperial Irrigation District.

The route of the AAC transected areas of highly permeable sediment and soils, including the sand hills of the Algodones Dunes, which resulted in substantial seepage loss from the canal. Seepage effects were noted during construction of the canal, and downslope land flooded when the canal was first filled with water. As a result, several sections of the canal east of Pilot Knob were lined with 6 in. of clay (Watt, 1994). Additional efforts to reduce seepage west of Pilot Knob included dumping truckloads of clay in the canal with the hope that it would be distributed by water flow (Watt, 1994). Seepage from the canal varied along its length and was controlled by the permeability of the canal bottom and sediments beneath the canal and by the hydraulic gradient between the canal water and groundwater elevations. Loeltz and Leake (1979) used a two-layer numerical model that estimated lining both the Coachella Canal and AAC would reduce annual seepage from the AAC between Pilot Knob and Drop 1 by 57,000 acre-ft in 1985 and by 39,000 acre-ft in 2030. Estimates of seepage from the canal between Pilot Knob and Drop 1, based on unaccounted-for differences between flow measurements (corrected for diversions and evaporation), ranged from 29,000 to 132,000 acre-ft/yr and had a median of 70,000 acre-ft per year during 1948-88 (Watt, 1994). Seepage loss was estimated by Tetra Tech (1999) by using seepage rates estimated on the basis of subsurface geology and hydraulic conditions for six structurally defined reaches along the canal. Estimates based on this work were about 60,000 acre-ft/yr from Pilot Knob to Drop 1 and 85,000 acre-ft per year from Pilot Knob to Drop 3.
Congress authorized the Secretary of the Interior to reduce or recover seepage from the AAC in the San Luis Rey Indian Water Rights Settlement Act (1988) by constructing "a new lined canal or to line the previously unlined portions of the AAC from the vicinity of Pilot Knob to Drop 4" or to "construct seepage recovery facilities in the vicinity of Pilot Knob to Drop 4." Federal funds were precluded by law from being used to eliminate or recover the seepage water from the canal; instead, funds were provided by a California State bond and from the San Diego County Water Authority. Various alternatives were considered to implement the law, which concluded with an agreement signed in 1994 to construct a 23-mi concrete-lined parallel canal. Construction of a new, lined AAC parallel to the older unlined AAC began in June 2007 and was completed in early 2010 (U.S. Bureau of Reclamation, 2012). The lined canal extends from Pilot Knob to Drop 3 and was estimated to conserve approximately 67,700 acre-ft of seepage water per year (U.S. Bureau of Reclamation, 2012). There were, however, two small stretches where Interstate 8 crosses the newly constructed 23-mi section of the AAC that were not lined.

The 123-mi-long Coachella Canal, unlined for the first $89 \mathrm{mi}$, was completed in 1948 to transport Colorado River water from Drop 1 of the AAC northwest to the Coachella Valley. The unlined portion of the Coachella Canal was 40 to $60 \mathrm{ft}$-wide at the bottom and had a water depth of $10.3 \mathrm{ft}$ and a capacity of 5,000 acre-ft/d (1,800,000 acre-ft/yr; U.S. Bureau of Reclamation, 2012). From 1955 to 1970, an estimated $140,000 \mathrm{acre}-\mathrm{ft} / \mathrm{yr}$ was lost to seepage along the first $49 \mathrm{mi}$ of the Coachella Canal. A concrete-lined canal was constructed in 1979-80 just east of the older reach of the Coachella Canal to replace its first $49 \mathrm{mi}$ (U.S. Bureau of Reclamation, 2012). A parallel, concrete-lined canal was constructed between 2004 and 2006 to replace the remaining $35 \mathrm{mi}$ of unlined canal (U.S. Bureau of Reclamation, 2012). The carrying capacity of the lined Coachella Canal is 2,600 acre-ft/d (940,000 acre-ft/yr; U.S. Bureau of Reclamation, 2012).

\section{The Lower Colorado Water Supply Project}

The Lower Colorado Water Supply Act (1986) authorized the Secretary of the Interior to construct well facilities along the AAC in the Algodones Dunes area of Imperial County, California, that have a total capacity not to exceed 10,000 acre-ft/yr. Groundwater from these LCWSP wells supplies water to non-agricultural California users who do not hold rights to Colorado River water or whose rights are insufficient to meet their present or anticipated future needs. Under a contract with the U.S. Bureau of Reclamation, IID and CVWD agreed to exchange a portion of their diversion rights from the Colorado River for an equivalent quantity and quality of groundwater from the LCWSP well field (U.S. Bureau of Reclamation, 1992). The exchanged water 
is delivered to the IID and the CVWD through the AAC. An acceptable limit on salinity of water delivered to IID and CVWD from the LCWSP well field was set at $879 \mathrm{mg} / \mathrm{L}$, plus or minus $30 \mathrm{mg} / \mathrm{L}$, on an average annual flow-weighted basis (U.S. Bureau of Reclamation, 2004); the salinity criterion has subsequently been waived by IID and CVWD through at least 2025 (State of California, 2007). In September 1992, the city of Needles, California, assumed responsibility for LCWSP beneficiaries in San Bernardino County, with subsequent extensions to beneficiaries in Riverside and Imperial Counties. Beneficiaries execute a subcontract for LCWSP water with the city of Needles that provides for repayment of costs associated with well-facilities construction and for costs of LCWSP administration. The first stage of the LCWSP was completed and began pumping in 1996, having a capacity to provide 5,000 acre- $\mathrm{ft}$ of water per year. The additional $5,000 \mathrm{acre}-\mathrm{ft} / \mathrm{yr}$ of water is to be produced by the LCWSP when a need for the water is identified and funding for the construction of additional facilities is available.

\section{Other Groundwater Development}

California Department of Water Resources identified three groundwater basins that intersect some portion of the study area: Yuma Valley, Ogilby Valley, and Imperial Valley (California Department of Water Resources, 2003, www.water.ca.gov/groundwater/bulletin118/update_2003.cfm, accessed October 30, 2012). Few production wells, consisting mainly of domestic-use or stock wells, have been drilled on the East Mesa or in eastern Imperial Valley. Groundwater pumping in the Imperial Valley was estimated to be about $25,000 \mathrm{acre}-\mathrm{ft} / \mathrm{yr}$ (Tompson and others, 2008). Shallow wells on the Pilot Knob Mesa, near the piedmont of the Chocolate and Cargo Muchacho Mountains, yield potable water, and water in deeper wells is typically higher in dissolved solids (McDonald and Loeltz, 1976). Pumping from wells in this portion of the study area is subject to Colorado River Accounting Surface regulations required by the 1964 U.S. Supreme Court decision Arizona v. California (OwenJoyce and others, 2000), specifying that the Secretary of the Interior must account for the consumptive use of water from the mainstream of the Colorado River.

\section{Geology}

\section{Landforms}

The majority of the study area comprises the uplands of the Pilot Knob and East Mesas, and the Algodones Dunes. The Pilot Knob Mesa extends from the west slope of the Cargo Muchacho Mountains southwestward to the Algodones Dunes and southward to Pilot Knob; the East Mesa is the westward extension of the Pilot Knob Mesa (fig. 1). The surface of the Pilot Knob Mesa is dissected by washes and partly covered both by locally derived and distant-sourced desert pavement. The surface of the East Mesa is generally composed of windblown sand to a depth less than $20 \mathrm{ft}$ below land surface (bls). The western boundary of the East Mesa is the shoreline of the prehistoric Lake Cahuilla - a group of lakes that formed when the Colorado River periodically flowed inland through the Salton Trough (Waters, 1983). The lakes evaporated around 1500, creating a dry playa (Wilke, 1978). The surface sediments of the East Mesa are derived from the regressive and barrier beaches of ancient Lake Cahuilla (Van de Kamp, 1973). The East Mesa is bounded by the Sand Hills fault on the east.

The Algodones Dunes trend southeastward and lie on a southwestward- to westward-sloping surface that is continuous with the Pilot Knob and East Mesas (fig. 1). The sands are of aeolian origin derived primarily from Colorado River sediments deposited in the ancient Lake Cahuilla (Norris and Norris, 1961; McCoy and others, 1967; Van de Kamp, 1973; Winspear and Pye, 1995; Stokes and others, 1997). The dunes are well-sorted fine to medium sand, are $46 \mathrm{mi}$ long and up to $6.5 \mathrm{mi}$ wide, and can exceed $300 \mathrm{ft}$ in height. The dunes have been moving toward the southeast; rates of movement for individual transverse megadunes over the last 100-200 years have ranged from 6.6 to 16 feet per year (ft/yr; Stokes and others, 1997). Additionally, the dune field has been migrating to the east at an average rate of about $0.054 \mathrm{ft} / \mathrm{yr}$ (Stokes and others, 1997).

\section{Structural Features}

The Salton Trough is an active rift between the Pacific and North American plates. Since the Miocene Epoch, sediments have accumulated above the basement complex in this region as the Gulf of California opened along a complex network of faults and spreading centers (Parsons and McCarthy, 1996; Umhoefer, 2011). The Sand Hills fault and the Algodones fault, which bound the Algodones Dunes to the west and east respectively, are commonly mapped as some of the locally eastern-most faults of the Salton Trough (Kovach and others, 1962; Meidav and Furgerson, 1972; Mattick and others, 1973; Fuis and others, 1984; Parsons and McCarthy, 1996; California Geological Survey, 2010). These faults have been described as possibly being "fossil" (no longer active) transform faults or spreading centers (Lonsdale, 1989) associated with the formation of the Salton Trough. The presence of geothermal systems along basement highs underneath the Sand Hills fault could reflect remnants of these spreading centers (Dunes Geothermal Anomaly, fig. 1; Rex and others, 1971; Parsons and McCarthy, 1996). 
Initial Characterization of the Groundwater System near the Lower Colorado Water Supply Project, Imperial Valley, Calif.

The Algodones fault is well defined in the Yuma, Arizona, area to the southeast of the LCWSP (Mattick and others, 1973; Olmstead and others, 1973), but it is unclear if the Algodones fault in Yuma connects to the Algodones fault identified along the eastern edge of the Algodones Dunes. In the Yuma area, the Algodones fault is a dip-slip fault, where the basement is downthrown to the southwest (Olmstead and others, 1973) and the water table is offset across the fault, indicating it acts as a groundwater barrier (Olmstead and others, 1973; Dickinson and others, 2006). Mattick and others (1973) mapped this fault as extending northwestward from the Yuma area, crossing the AAC approximately just west of Pilot Knob (fig. 1), but disconnected from the Algodones fault farther north. A geophysical cross-section along the AAC from Pilot Knob westward (Mattick and others, 1973) indicated that there is no vertical displacement along a fault in this area, although there was some uncertainty in these findings. Gravity work completed as part of this study (appendix 2) indicated the presence of the Algodones and Sand Hills faults near the AAC, but did not find evidence of vertical displacement along these faults near the AAC. There is no evidence, therefore, to indicate that either of these faults acts as a groundwater barrier in the area of the LCWSP.

\section{Stratigraphy}

The Salton Trough is filled with a thick sequence of dominantly non-marine sedimentary rocks that ranges in age from Eocene to Holocene. The aggregate thickness of this sequence is many thousands of feet, both in exposures and beneath the Imperial Valley in the central part of the Salton Trough. Rocks as old as Eocene crop out in the bordering mountains, but the fill in the central part of the trough does not appear to be older than about middle Miocene, and most of the fill is Pliocene or younger (Durham, 1954). These deposits are grouped into three broad categories (1) a lower sequence comprising chiefly non-marine sedimentary rocks of early to middle Tertiary-age, but also including volcanic rocks and minor marine sedimentary rocks; (2) a middle marine unit, the Imperial Formation, of late Tertiary (Miocene or Pliocene) age; and (3) an upper sequence composed of predominantly non-marine deposits of late Tertiary- (Pliocene) and Quaternary-age. This current study was primarily concerned with groundwater in the upper few thousand $\mathrm{ft}$ bls, which constitutes the main part of the groundwater reservoir; the following stratigraphic description, therefore, focuses on the upper stratigraphic sequence.

Most of the heterogeneous sediments in the upper sequence were deposited by the Colorado River, but in some marginal tributary valleys the deposits were derived locally (Loeltz and others, 1975). The unit is many hundreds to thousands of feet thick; up to $13,400 \mathrm{ft}$ of Colorado River deposits have been recognized below central Imperial Valley in several oil test wells (Muffler and Doe, 1968). The deposits of the Colorado River predominantly consist of discontinuous silt, sand, and clay deposited in deltaic and lacustrine facies. The locally derived deposits along the basin margins predominantly consist of coarse sand and gravel deposited in alluvial fans and braided stream facies. The upper sequence has been subdivided by previous authors into several formations, but in general, these formations are not laterally continuous (Loeltz and others, 1975).

\section{Hydrology}

The groundwater reservoir (or aquifer system) in the Imperial Valley consists of Tertiary valley-fill deposits underlain by pre-Tertiary-age rocks that are referred to as the basement complex (Loetz and others, 1975). In this report, the valley-fill deposits are grouped into an upper aquifer system of Quaternary deposits and a deeper aquifer system consisting of Tertiary and older deposits. Although these deposits as a whole are more than $20,000 \mathrm{ft}$ thick in the center of the Imperial Valley, the primary zone for water supply is the non-marine deposits in the upper few thousand feet of the aquifer system. At depths greater than a few thousand feet, the groundwater commonly is too saline for irrigation and most other uses, and the hydraulic connection between the water in the deeper aquifer system and the water in the upper aquifer system is poor (Loeltz and others, 1975). Thus, the data and discussions in the following sections focus on the upper aquifer system.

\section{Aquifer System}

The upper aquifer consists of the saturated part of the Quaternary deposits and is generally unconfined. This aquifer system could be stratigraphically equivalent and hydraulically continuous with the water-bearing deposits in the Yuma area described by Olmstead and others (1973) as an upper, finegrained zone, middle coarse-gravel zone, and lower wedge zone; these deposits appear to extend into the eastern-most part of the study area. The upper aquifer appears to be no more than 2,000-2,500 ft deep in most areas (Olmstead and others, 1973; Tompson and others, 2008).

Previously published borehole lithologic data from sites along the AAC upstream from the Coachella Canal diversion were used to investigate the stratigraphy and aquifer system in the area of the LCWSP well field (see "Documentation and Archival of Historical and non-USGS data"; fig. 2). The lithology at all of the boreholes is primarily sand, alternating with layers containing clay, silt, and gravel; the layers are likely to be discontinuous between boreholes. Descriptions provided for the two deepest boreholes, LCRP-6A to the southwest and AAC-12 deep to the northeast, indicated partially cemented sand layers near the bottom of each borehole. This change in cementation could represent a transition to partly consolidated deposits of older alluvium. Geophysical logs and lithologic descriptions for well LCRP-6A indicated that the unconsolidated Quaternaryaged deposits of the upper aquifer could be as much as 1,700-ft-thick along the AAC at the Coachella Canal. 

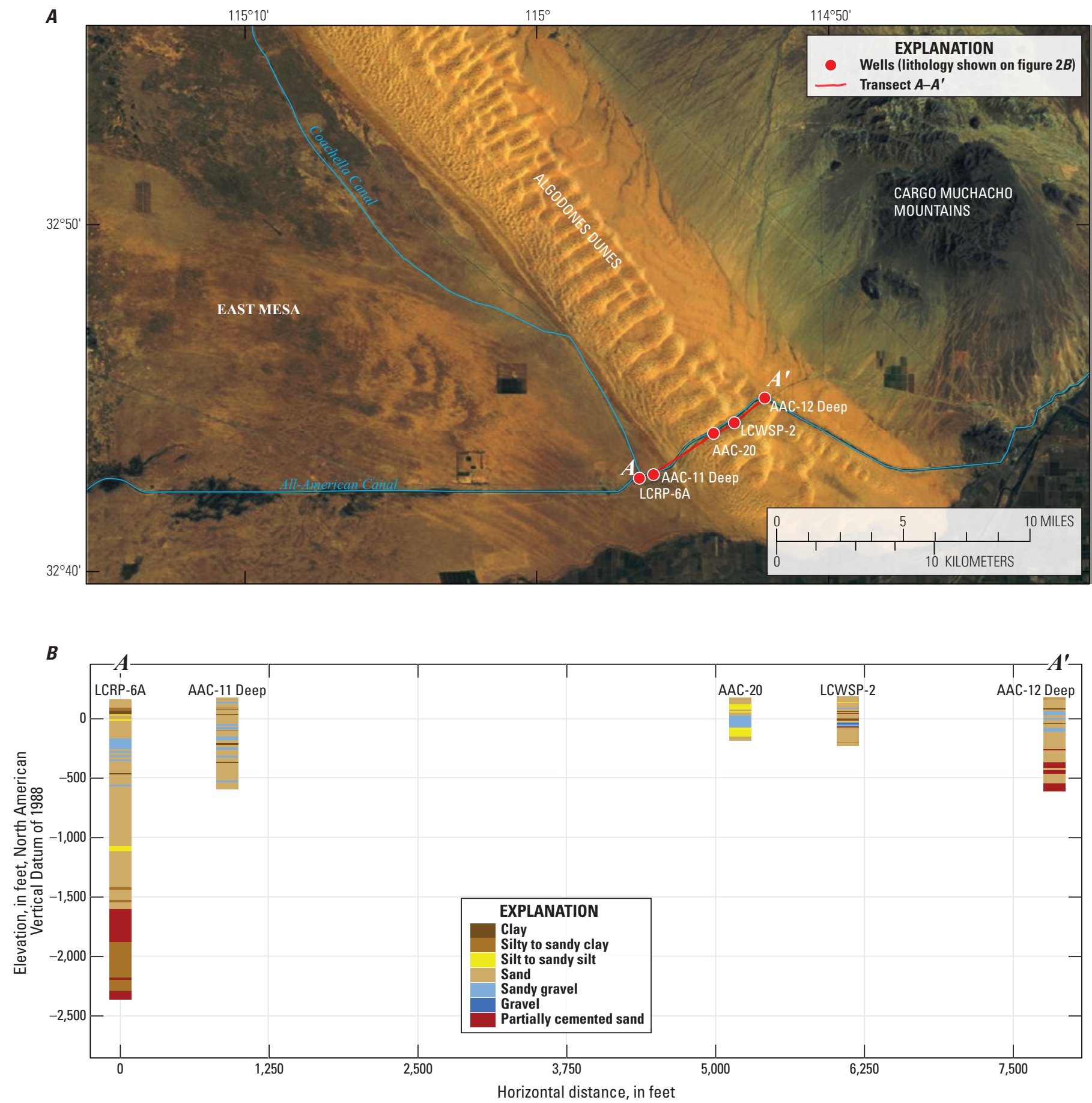

Figure 2. Transect $A-A^{\prime}$ in the study area by the Lower Colorado Water Supply Project, Imperial Valley, California: $A$, aerial photograph with location of transect $\mathrm{A}-\mathrm{A}^{\prime} ; B$, cross section of stratigraphy along transect $\mathrm{A}-\mathrm{A}^{\prime}$. 


\section{Recharge and Discharge}

The hydrologic history of the study area is important to consider with regard to recharge and water quality because the origin of the groundwater (marine or freshwater, Colorado River water or local precipitation) and the aquifer materials in contact with the groundwater affect the groundwater quality. Stratigraphic evidence in the Imperial Formation indicates that the last major marine incursion into the Salton Trough was in the late Tertiary Period, possibly as recently as the Pliocene Epoch (Loetz and others, 1975). As a result, water that recharged these deposits, the upper part of the deeper aquifer, was of marine origin and saline.

Water that recharged the upper aquifer was primarily fresh water from the Colorado River, deposited when the historic Colorado River periodically flowed inland through the Salton Trough to produce Lake Cahuilla (Waters, 1983). Avulsion of the Colorado River from the Salton Trough back into the Gulf of California caused the ancient Lake Cahuilla to become a closed-basin lake subject to evapoconcentration and deflation. There is evidence of several lacustrine events when the Colorado River flowed into the Salton Trough, but the youngest and most prominent lacustrine shorelines have been estimated to be several hundred to about 4,000 years old (Stokes and others, 1997). There is some dispute among previous researchers, however, about the nature of the historic lakes in the Salton Trough some researchers believed that non-marine, freshwater, conditions predominated (Tarbet and Holman, 1944; Dibblee, 1954; Hubbs and others, 1963; Thomas, 1963), but other researchers believed that the lakes must have been brackish (Mendenhall, 1909b; Downs and Woodard, 1961; Robinson, 1965). In either case, recharge to these deposits and the upper aquifer was probably not of marine origin.

Groundwater in the study area is recharged naturally near the mountain fronts along the washes from precipitation runoff and by underflow from the east between the Cargo Muchacho Mountains and Pilot Knob. Since 1940, groundwater has been recharged along the AAC and Coachella Canal from seepage of Colorado River water. Irrigation-return flow could also recharge the aquifer system in the Imperial Valley, despite tile (subsurface) drains (Tompson and others, 2008).

Groundwater in the study area generally moves west and northwest toward the central axis of the Imperial Valley and then northward toward the Salton Sea (Loeltz and others, 1975). During the period when the AAC was unlined (19402006), groundwater also flowed southward from the canal toward the International Border. Discharge from the aquifer system is primarily by evaporation from the Salton Sea and the irrigated fields in the center of the valley. Discharge also has been observed at springs and seeps along the lower reaches of the New and Alamo Rivers (Loeltz and others, 1975), although it is unclear if this is currently true. In addition to evapotranspiration from irrigated fields, captured irrigationreturn flow is drained by subsurface drains beneath irrigated fields. Pumping discharges groundwater in the LCSWP well field and in the Imperial Valley.

\section{Hydraulic Properties}

Pumping tests were done by Loeltz and others (1975) on four wells in the study area to determine hydraulic properties. These wells ranged in depth from 140 to $894 \mathrm{ft}$ bls and were perforated in the upper aquifer. In three wells in the East Mesa, the pumping tests yielded transmissivities ranging from 140,000 to 240,000 gallons per day/ft, and at a well in the Algodones Dunes, a transmissivity of 850,000 gallons per day/ft was determined. Average field hydraulic conductivities from these tests ranged from a low of 32 feet per day (ft/d) to a high of $1,300 \mathrm{ft} / \mathrm{d}$. The moisture content of soil profiles determined by Loeltz and others (1975) ranged from nearly 30 percent beneath mesas and in other areas where deposits are primarily coarse textured to 40 percent in the fine-grained deposits outside of irrigated areas. Specific-yield values estimated by Dutcher and others (1972) ranged from 5 percent in deep and (or) fine-grained deposits to 20 percent in coarsegrained alluvial deposits.

\section{Methods of Investigation}

Characterization of the aquifer system in the study area involved reviewing hydrologic and geologic information from previous reports (described earlier in this report), compiling historical hydrologic and water-quality data, and establishing a monitoring network for collection of new geohydrologic and water-quality data. A new well was constructed where additional data were needed. Focused data collection in an existing well provided a wellbore-velocity profile, depthdependent water-quality samples, and aquifer-test data. New surficial geophysical data were collected by using a timedomain electromagnetic survey and microgravity surveys.

\section{Documentation and Archival of Historical and non-U.S. Geological Survey Data}

Discrete groundwater elevations collected prior to 2009 , the start of this study, were obtained from various sources. More than 200 wells that had groundwater-elevation measurements were identified in the USGS National Water Information System (NWIS) database. Additional groundwater-elevation data from over 100 wells that were not in NWIS were obtained from USGS reports dated prior to the advent of the NWIS database and from the U.S. Bureau of Reclamation, IID, and private consulting companies. These groundwater elevations were quality-assured and added to NWIS for archival purposes. The period that had the best areal coverage of groundwater-elevation data in the study area prior to 2009 was $1998-99$. 
Continuous groundwater elevations collected prior to this study were obtained from NWIS and from private consultants. Continuous data from three wells (AAC-20, Site 2, Drop 1 Pilot) were recorded by the USGS beginning in 2000 and continuing through 2011. Additional continuous data from 32 shallow monitoring wells along the AAC were recorded by consultants during 2005-07. The data from the consultants were quality assured and archived in the NWIS database.

Surface-water and groundwater quality and isotope data collected from 1917 to 2008 were obtained from various sources. Water-quality data for the Colorado River upstream from Imperial Dam were already in the NWIS database; additional data from 159 samples for groundwater sites were also in the database. Supplemental sample data from the Colorado River and groundwater sites were obtained from the U.S. Bureau of Reclamation and published reports (Coplen and Kolesar, 1974; Payne and others, 1979; Tompson and others, 2008). The period that had the best areal coverage of water-quality data collected prior to 2009 was 1960-65.

Lithologic and geophysical borehole data were compiled from the USGS, driller's reports, IID, Reclamation, and consultants. Most borehole data described depth intervals in the upper 1,000 ft of sediments; only three boreholes in the study area had data collected from greater than $1,000 \mathrm{ft}$ in depth.

\section{Monitoring Network}

Each well identified from NWIS, historical USGS reports, and non-USGS sources was assessed to determine if the well was usable for data collection as part of this study. Well locations, elevations, and construction data were verified and updated in the NWIS database. Over 150 wells that were not previously in NWIS were identified, assessed, and added to the USGS NWIS database.

A subset of the wells was included in a monitoring network for collecting groundwater elevations and groundwater-quality data. Wells were selected for inclusion in the network based on spatial location, depth, casing condition, and access to measure the groundwater elevation and to collect a groundwater-quality sample. Many of the wells selected for the network were observation wells that had not been pumped for several decades. Prior to data collection, these wells were redeveloped to ensure that each well was hydraulically connected to the aquifer. Well development entailed air surging and pumping the well for a minimum of 1 hour or until the pump-discharge water appeared clear.

\section{Groundwater Elevations}

From 2009 to 2011, the USGS measured groundwater elevations in a network of 39 wells in the study area (fig. 3; see appendix table 1-1). Groundwater elevations in wells were measured every 1 to 3 months, to one-hundredth of a foot (reported to one-tenth of a foot). Eleven of the network wells were instrumented with pressure transducers; groundwater elevations were recorded hourly in these wells (P-6.4, AAC-12 Deep, PK-1, AAC-20, Drop 1 Pilot, P-1.3, LCRP-18, 15Q1, CH-4, Site 2, PK-7). Groundwater elevations were computed by subtracting the groundwater level below land surface from the land-surface elevation, as defined by the National Geodetic Vertical Datum of 1988 (NGVD88). Land-surface elevations at wells were measured by using a differential survey-grade global positioning system (GPS) and have an accuracy of plus or minus $0.5 \mathrm{ft}$.

\section{Groundwater Quality}

From 2009 to 2011, the USGS collected 45 groundwaterquality samples from 24 wells in the study area as part of this study (fig. 4; see appendix table 1-2). Samples were analyzed for field parameters and concentrations of major ions and trace elements to characterize groundwater quality, for the stable isotopes of oxygen and hydrogen to identify groundwater sources, and for the radiogenic isotopes tritium and carbon-14 to determine groundwater ages. In addition, from 2007 to 2009 the USGS collected three groundwater-quality samples from three wells in the study area as part of the Groundwater Ambient Monitoring and Assessment (GAMA) Program Priority Basin Project (Gold Rock Ranch, IID Drop 4, and CHP Felicity wells; fig. 4; see appendix table 1-2; Goldrath and others, 2010; Mathany and others, 2012). To ensure highquality data, internal USGS quality-assurance procedures were followed, and quality-control samples were collected (appendix 3).

Standard USGS equipment and procedures were used during groundwater-quality sampling, as outlined in the National Field Manual for the Collection of Water-Quality Data ("field manual," U.S. Geological Survey, variously dated). Before samples were collected, the depth-to-water in the well casing was measured, and wells were pumped to purge at least three casing volumes of water. During the purging of water, temperature, $\mathrm{pH}$, specific conductance, and dissolved-oxygen concentrations were measured by using individual meters; field parameters were recorded, and samples were collected, after three sequential field measurements were stable (to within the criteria specified in the field manual). Samples for the determination of all major ions and trace elements were collected after they had passed through a 0.45 -micrometer in-line cartridge filter. One milliliter of nitric acid (70 percent) was used to preserve 250-milliliter samples for trace-element analyses and some major-ion analyses. Major ions and trace elements were analyzed by the USGS National Water-Quality Laboratory (NWQL) in Lakewood, Colorado. Stable isotopes of hydrogen and oxygen were analyzed by the USGS Reston Stable Isotope Laboratory in Reston, Virginia; tritium was analyzed by the USGS Water-Quality Laboratory in Menlo Park, California; and carbon-14 was analyzed by the National Ocean Sciences Accelerator Mass Spectrometer (NOSAMS) Facility in Woods Hole, Massachusetts. 


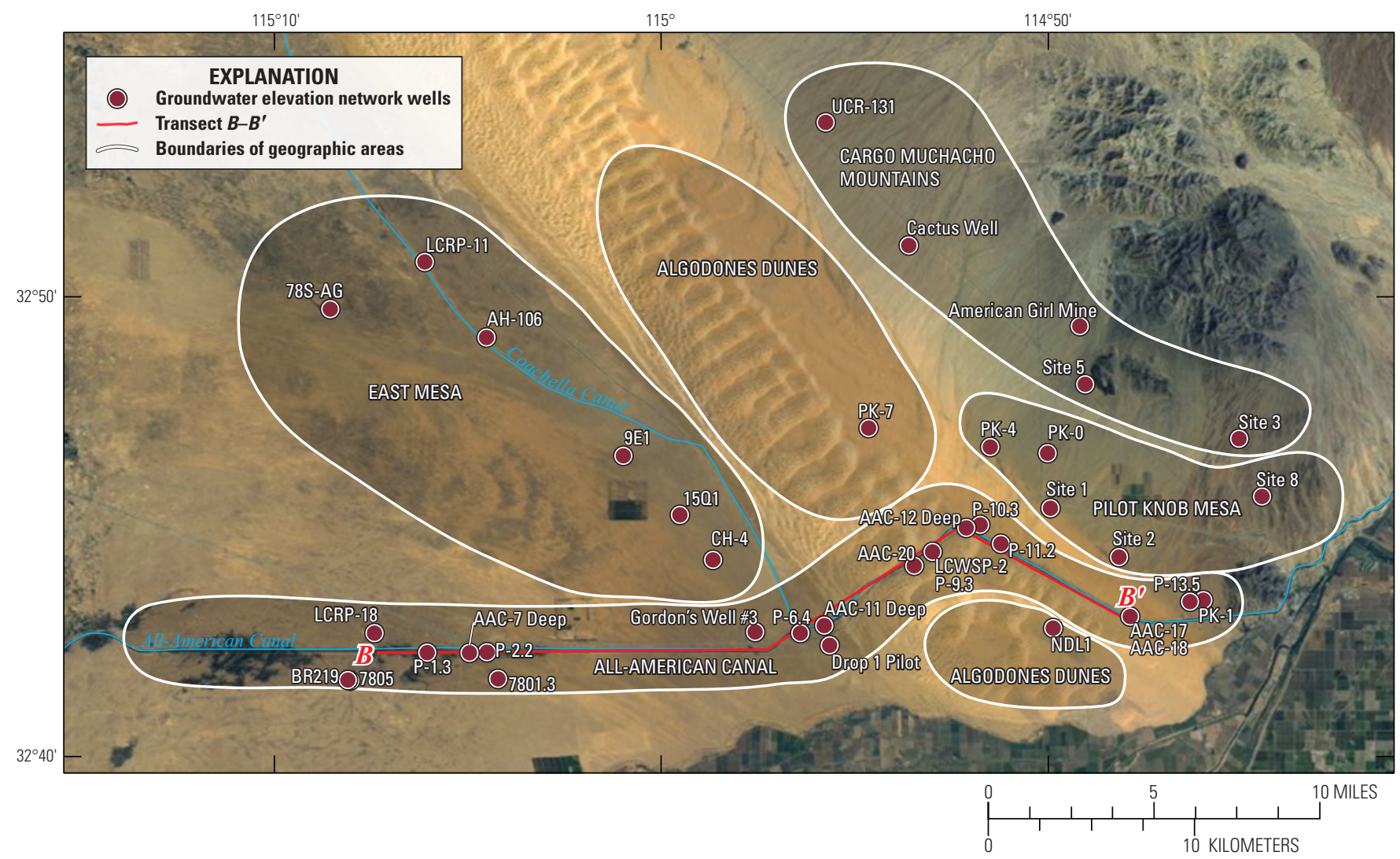

Figure 3. Location of the groundwater-elevation network wells, geographic areas, and transect B-B', Imperial Valley, California.

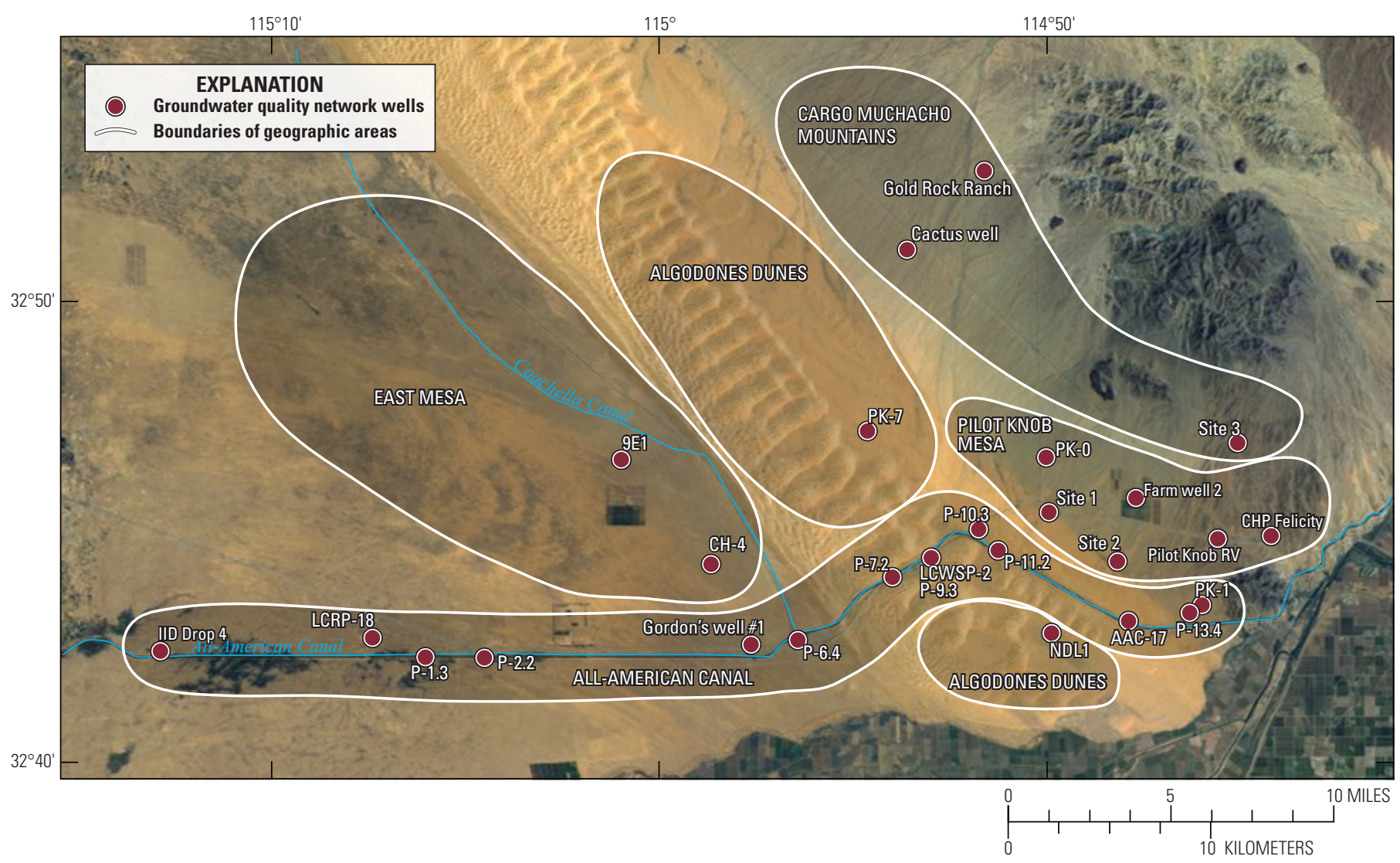

Figure 4. Location of the groundwater-quality network wells and geographic areas, Imperial Valley, California. 
Ratios of the stable isotopes of oxygen and hydrogen were used to identify sources of groundwater recharge. These isotopic rations are expressed in delta $(\delta)$ notation as per mil (parts per thousand) differences relative to the standard known as Vienna Standard Mean Ocean Water (VSMOW; Gonfiantini, 1978).The ratio of oxygen isotopes, $\delta^{18} \mathrm{O}$, is expressed as the ratio of oxygen-18 $\left({ }^{18} \mathrm{O}\right)$ to the more common isotope, oxygen-16 $\left({ }^{16} \mathrm{O}\right)$ relative to the ratio in VSMOW. The ratio of hydrogen isotopes, $\delta^{2} \mathrm{H}$, is expressed as the ratio of hydrogen- $2\left({ }^{2} \mathrm{H}\right)$ to the more common isotope hydrogen-1 $\left({ }^{1} \mathrm{H}\right)$ relative to the ratio in VSMOW. Tritium $\left({ }^{3} \mathrm{H}\right)$, a short-lived radioactive isotope of hydrogen with a half-life of 12.32 years, was used to determine the presence of water recharged since 1953, when large amounts of ${ }^{3} \mathrm{H}$ were released to the atmosphere during above-ground testing of nuclear weapons (Michel, 1976). Carbon-14 $\left({ }^{14} \mathrm{C}\right)$, a radioactive isotope of carbon with a half-life of 5,730 years, was used to estimate groundwater ages ranging from about 1,000 to less than 30,000 years before present. Carbon-14 activity in groundwater is expressed as percent modern carbon (pmC) and reflects exposure to the atmospheric ${ }^{14} \mathrm{C}$ source (Mook, 1980; Kalin, 2000). The ${ }^{14} \mathrm{C}$-based age of the water is calculated on the basis of the decrease in ${ }^{14} \mathrm{C}$ activity due to radioactive decay since groundwater recharge relative to an assumed initial ${ }^{14} \mathrm{C}$ concentration. Calculated ${ }^{14} \mathrm{C}$-based groundwater ages in this study are referred to as "uncorrected" because they have not been adjusted to account for exchange with sedimentary sources of carbon or for the input following nuclear testing during the 1950 s. In general, uncorrected ${ }^{14} \mathrm{C}$ ages are older than the actual age of the associated water.

\section{New Well Construction}

To provide greater spatial coverage and enhance the monitoring network, a monitoring well was constructed near the international border (NDL1; fig. 3). A borehole was drilled to $149 \mathrm{ft}$ bls by the USGS Western Region Research Drilling Unit using an auger rig (CME55) fitted with 8.5-in.-diameter auger flights. The monitoring well was constructed by using flush-threaded, 2-in.-diameter schedule-80 polyvinyl-chloride (PVC) casing. The screened interval was constructed by using a 10-ft section of slotted PVC (slot size is 0.020 in.), pre-packed with Monterey No. 3 sand, from 138 to $148 \mathrm{ft}$ bls. After casing construction, each auger flight was pulled, and the vacated section of borehole backfilled with Monterey No. 3 sand to a depth of $57 \mathrm{ft}$ bls. A low-permeability bentonite grout (time-release pellets or No. 8 granules) was added from $57 \mathrm{ft}$ bls to the land surface to seal the borehole.

After completing the well in May 2011, natural gamma radiation and electromagnetic conductivity borehole geophysical logs were run (fig. 5). The monitoring well then was developed by using a portable submersible pump. Specific conductance, temperature, turbidity, discharge rate, and total volume were recorded during this process. Development was continued until the turbidity was below 10 nephelometric turbidity units and other field measurements had stabilized.

\section{Down-Hole Investigations}

Down-hole investigations of well LCWSP-2 were done to further characterize the groundwater-flow system and groundwater quality in the area of the LCWSP. Well LCWSP-2 was chosen for these investigations because it had the deepest screened interval that could be sampled in the study area and because the area of the LCWSP well field was of the greatest interest for the purpose of this study. Well LCWSP-2 produces water from a 200-ft-long, 16-in.-diameter, screened interval $200-400 \mathrm{ft}$ bls that is in a sequence of predominantly coarse-grained deposits of sand and gravel with some thin layers of clay and silt.

Specialized sampling techniques were used to construct a wellbore-velocity profile and to collect water-quality samples from different depth intervals within the screened portion of the well (Izbicki and others, 1999). The purpose of this field test was (1) to characterize the relative inputs of groundwater from various depths of the aquifer to the total amount of water pumped from the well and (2) to characterize groundwater quality with depth. In addition, an aquifer test was done to collect groundwater-drawdown data over time to calculate average hydraulic property estimates for the aquifer around well LCWSP-2.

\section{Depth-Dependent Wellbore-Velocity Profile and Groundwater-Quality Sampling}

A wellbore-velocity profile with depth was constructed by using a tracer-pulse (dye-injection) method (Izbicki and others, 1999) to provide information about the relative proportions of water entering well LCWSP-2 from different depths under pumping conditions. Dye-injection tests were performed from August 26 to 27, 2009, at 10 depths ranging from 200 to $390 \mathrm{ft}$ bls. The data from these injection tests (the dye arrival times) were used to calculate the contribution to wellbore flow between each dye-injection point; the results from each injection point were compiled to create the wellbore-velocity profile. Multiple tests were performed at each depth. Additionally, the flow rate of discharge from the entire well (combined well discharge) was recorded by using a flow meter at the wellhead.

Discrete water-quality samples were collected at $240 \mathrm{ft}$, $280 \mathrm{ft}, 350 \mathrm{ft}$, and $385 \mathrm{ft}$ bls under pumping conditions by using a small-diameter pump, as described by Izbicki (2004; see appendix table 1-3). Water-quality samples collected at each depth represented an integrated sample of the upward flowing water from the sampled depth to the bottom of the screened interval under pumping conditions. A sample of the combined well discharge, representing the entire screened interval of 200-400 ft, also was collected from a spigot off the discharge pipe at land surface. 


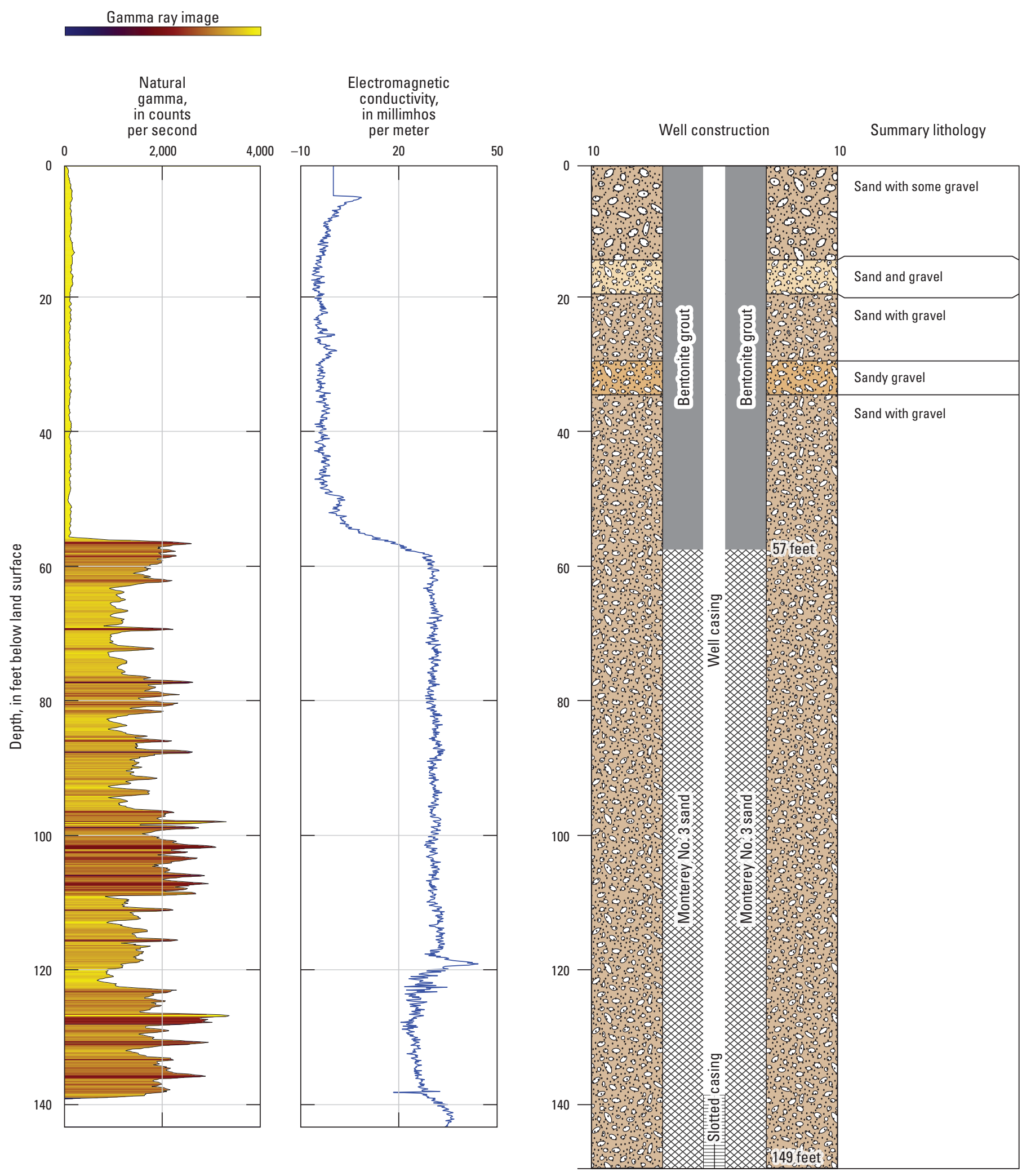

Figure 5. Natural gamma radiation and electromagnetic conductivity logs, well construction, and lithology of well NDL1, Imperial Valley, California. 


\section{Aquifer Test}

On August 18, 2009, the USGS began continuously monitoring (in 15-minute intervals) the groundwater elevations in well LCWSP-2, which was pumped at a constant rate of 3,000 gallons per minute (gpm). On August 31, 2009, at 9:07 a.m. Pacific Standard Time (PST), the pump was turned off, and the groundwater recovery was monitored in 1-minute intervals for approximately 48 hours (until September 2, 2009, at 9:03 a.m. PST). The pump was turned on again on September 2, 2009, at 9:04 a.m. PST, and the groundwater drawdown was recorded in 1-second intervals until 12:08 p.m. PST and, then, in 5-minute intervals through September 18, 2009. Because the transducers used were vented, no data adjustments were necessary for barometric effects; no adjustments were made for potential effects associated with earth tides or temperature.

The Tartakovsky-Neuman method (Tartakovsky and Neuman, 2007) was used to fit a solution to the measured groundwater recovery and drawdown data (fig. 6). The Tartakovsky-Newman method estimates hydraulic properties of unconfined aquifers, and the method accounts for partial penetration of the test well. Based on trial and error fitting of the solution to the observed drawdown data, a saturated thickness of 5,600 ft was used in the simulation for the overall thickness of the aquifer. The Tartakovsky-Neuman solution yielded an estimated hydraulic conductivity of $46 \mathrm{ft} / \mathrm{day}$ and a specific yield of 0.2. The aquifer-test data are stored in the USGS California Water Science Center slug- and aquifer-test archive in San Diego, California.

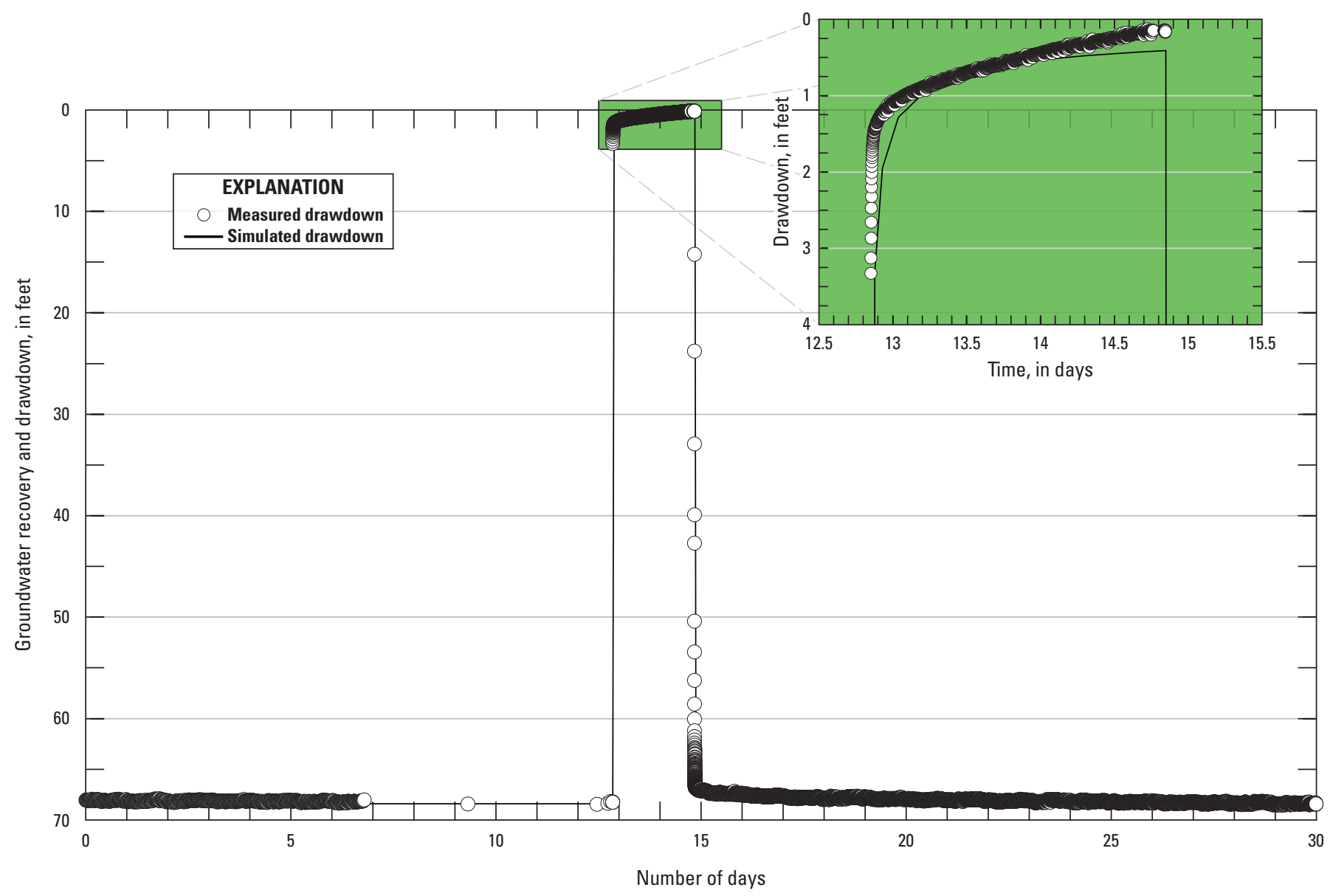

Figure 6. Measured and modeled groundwater recovery and drawdown during an aquifer test, well LCWSP-2, Imperial Valley, California, August 18-September 18, 2009. 


\section{Time-Domain Electromagnetic Survey}

The TEM soundings were made on a transect from the AAC to the Cactus well (fig. 7) to identify differences in groundwater salinity with increasing depth and distance from the AAC. Reconnaissance TEM soundings between the AAC and the Cactus well were completed in April 2010. Additional TEM soundings were completed in January 2011, for a total of 27 locations investigated overall.

TEM is an inductive technique that provides a measure of subsurface electrical resistivity by passing a current through a wire loop that generates a primary magnetic field by Ampere's law (Fitterman and Labson, 2005). This primary current is rapidly turned off, thereby causing a time-varying change in magnetic flux, $\varnothing_{m}$, which induces voltages, $\mathrm{V}$, and, hence, eddy currents, in conductive bodies, according to Faraday's law:

$$
V=d \phi_{m} / d t
$$

where

$$
\phi_{m}=\int \bar{B} \times d \bar{A}
$$

$$
\begin{aligned}
B & \text { is the magnetic induction, and } \\
d A & \text { represents an elemental effective area. }
\end{aligned}
$$

In TEM, secondary magnetic fields are produced by the decay of subsurface eddy and galvanic currents and are typically measured as a voltage at one or more surface receivers. In accordance with Faraday's law, a vertical receiver coil measures the product of the rate of change of the vertical component of $B$, the area of the receiver coil, and the number of turns in the receiver coil. The change in the voltage with respect to time can be converted into apparent electrical resistivity by time, which can be used to estimate resistivity for a one-dimensional (1-D) layered-earth environment through inverse modeling. Inverse modeling solutions are nonunique; therefore, any number of models can be developed that will fit the data with the same error. Known (borehole data) and estimated (gravity) geologic information, in addition to analysis of TEM data statistics, is relied upon to select the model solution most likely to represent the subsurface best at each sounding.

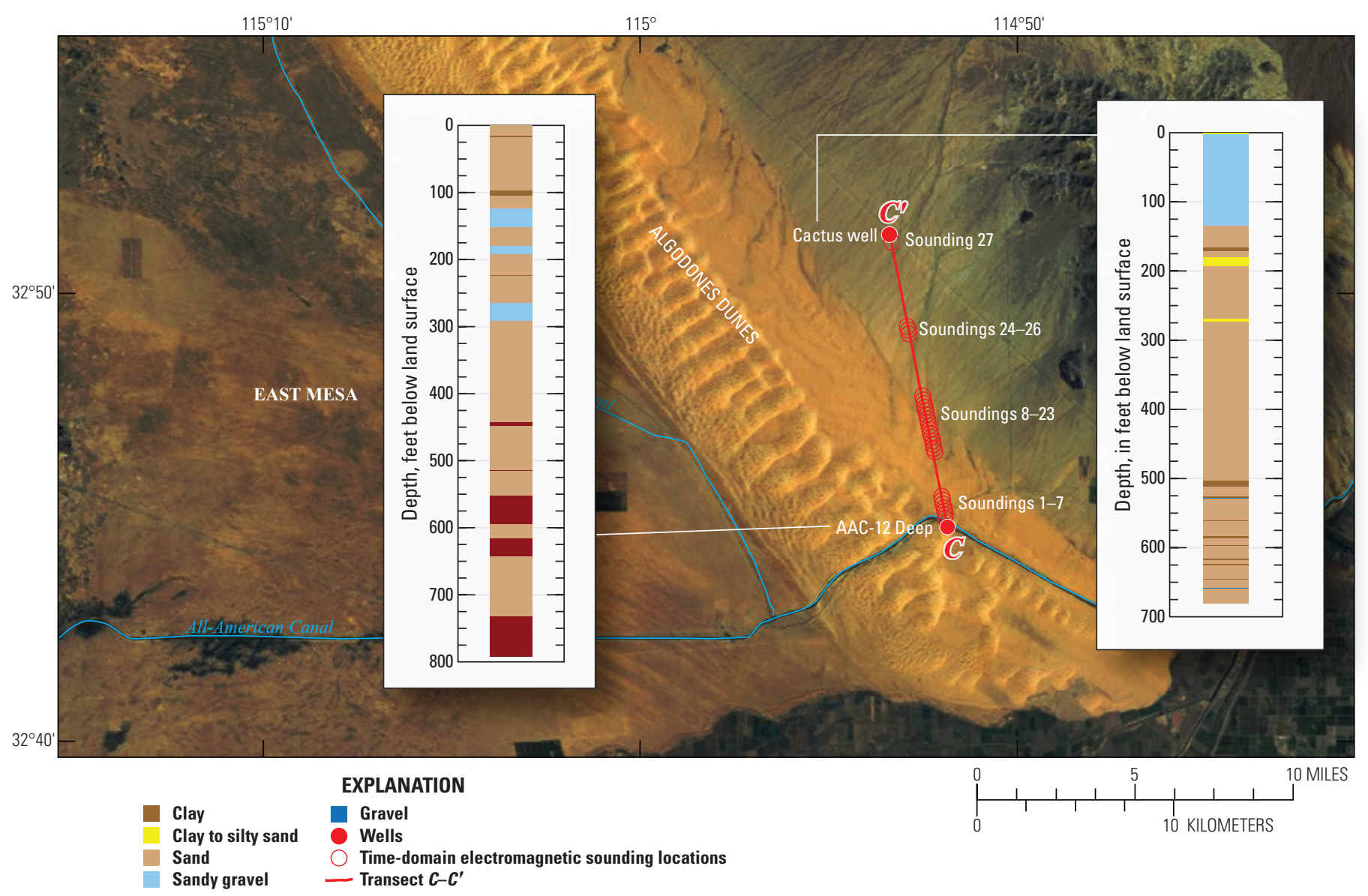

Figure 7. Location of transect $\mathrm{C}-\mathrm{C}^{\prime}$, the time-domain electromagnetic soundings (unfilled circles), and selected wells (filled circles) that includes borehole lithologic logs of AAC-12 Deep and Cactus Well, Imperial Valley, California. 
Electrical resistivity values for common near-surface earth materials vary by orders of magnitude, typically from $1 \mathrm{ohm}$-meter (ohm-m) or less for clays or alluvium saturated with high-salinity water to $1,000 \mathrm{ohm}-\mathrm{m}$ or more for dry carbonates or crystalline rocks (Palacky, 1987). In unsaturated sedimentary rocks, interstitial voids between mineral grains are filled with air and water. The resistivity of unsaturated sedimentary rocks depends on the mineralogy of deposits and the water content. The presence of water in pore spaces can dramatically decrease the resistivity of a geologic unit, especially in saturated sedimentary rocks, where these voids become electrically connected.

Clay-sized particles of any mineralogy can decrease formation resistivity because an increased surface charge results from the increased surface area of fine-grained particles (Baldridge and others, 2007); consequently, care must be taken when interpreting geophysical data collected from the land surface that is not accompanied by a lithologic log. Borehole resistivity and lithologic logs from the AAC-12 well at the southern end of the transect along which TEM data soundings were collected for this study, and from the Cactus well at the northern end of the transect, indicated that clay layers are likely not to be thick or laterally extensive in the upper $650 \mathrm{ft}$ of the nearby alluvial deposits (fig. 7). The lack of identifiable clay layers in the borehole logs at the start and terminus of the TEM traverse indicated that resistivity changes in the saturated zone could be attributed primarily to variations in groundwater salinity rather than variations in subsurface lithology.

A Zonge Engineering ZeroTEM system (Zonge Engineering, Tucson, Arizona) was used for this investigation. The system consisted of a Zonge ZT-20 transmitter connected to a 100 -meter (m) by 100 -m transmitter loop (Tx) that was excited with between 3.0 and 3.5 amps for each sounding. A Zonge TEM/3 antenna having a 10,000 square-m moment was used in conjunction with a Zonge GDP-32II multifunction receiver $(\mathrm{Rx})$ for all surveys. Responses were monitored for transmitter frequencies of 8,16 , or 32 hertz at each site with each configuration to obtain the deepest penetrating frequency with the least amount of noise at the end of the transient decay curve. Lower frequencies can allow for longer time intervals when the instrument is not transmitting and, therefore, provide more time to detect secondary fields originating at greater depths. Depending on the frequency, 20 to 25 time windows of data were collected at each sounding from zero to 12.14 milliseconds (msec). Field measurements were composited to provide an averaged normalized return for each time window, which were graphed for visual inspection of irregularities. Three repetitions of each sounding were averaged together.

TEM data can be negatively influenced by nearby conductors, such as metal fences, pipes, underground wires, overhead or buried power lines, and train tracks. Cultural interferences such as these were avoided where possible.
One guideline for TEM soundings was to keep the sides of the Tx loop about one loop length away from any cultural interference. Loops for this study had 100-m sides; therefore, all Tx loops were kept at least $100 \mathrm{~m}$ from any cultural interference.

TEM data were processed, and 1-D layered earth resistivity models were developed, by using Zonge Engineering's DATPRO suite of software. TEM sounding data were processed by inverse modeling by using Zonge's STEMINV software, which fits a model for each TEM time window to within 5 percent of the observed data. Well logs from AAC-12 deep and the Cactus well were compared to 1-D TEM models at the beginning and end of the TEM transect to constrain the best model. All TEM data and models were archived in the USGS Arizona Water Science Center geophysical data archive in Tucson, Arizona.

\section{Microgravity Surveys}

Gravity methods are based on the principles of Newton's Law of Gravitation (Telford and others, 1990), which states that the acceleration of gravity in an object's gravitational field is directly related to the mass of the object and inversely related to the square of the distance to the center of the object. Thus, the greater an object's mass, the stronger the gravitational field. The object that produces the gravitational field in this case is the Earth. Localized variations in the distribution of the Earth's mass, including those caused by groundwater in aquifers and water in the unsaturated zone, can cause localized variations in the Earth's gravitational field. Other subsurface mass change can also cause gravity changes at the surface of the Earth, such as movement of mass in magma and geothermal reservoirs.

Microgravity measurements were made by using relative- and absolute-gravity meters (see appendix table 1-4). Most microgravity data were collected by using relativegravity meters, which measure the difference in gravitational acceleration between stations. The absolute acceleration of gravity is established by measuring the value at selected stations by using an absolute-gravity meter. The absolute acceleration of gravity at other stations is then determined on the basis of the difference in gravity measured by using relative-gravity meters. Measurements of the relative differences in gravity among stations were made by using a Lacoste and Romberg Model D-127 gravity meter. Observations of absolute gravity were made by using an A10 absolute gravity meter built by Micro-g Lacoste.

The absolute gravity was monitored at eight stations on four north-south transects across the AAC (fig. 8; see appendix table 1-4). Each transect incorporated at least one station co-located with a monitoring well. Data were corrected for Earth tides, location of the rotational axis of the Earth, and barometric pressure ( -0.35 microgal, $\mu \mathrm{Gal}$, per millibar). 
Observations generally are accurate to within about plus or minus $2 \mu \mathrm{Gal}$, which is equivalent to the change in gravity resulting from the addition or removal of an extensive layer of water that is about 2 in. thick. Accuracy, however, can be degraded by ground motion caused by local construction activity, seismic activity, atmospheric disturbances, and large variations in temperature. During early gravity measurements, localized construction activity associated with lining the AAC was evidenced by larger error values associated with these gravity measurements near the canal (see appendix table 1-4). Temperature variations were minimized during data collection by placing stations in buildings or shading the instrument during measurement.

Relative-gravity surveys were completed by using 3-5 stations for each transect. Inclusion of stations where the absolute acceleration of gravity also was measured allowed for the calculation of absolute gravity at each station in the network. Surveys were reduced to gravity differences between stations by converting meter readings to gravity units and correcting for estimated Earth tides (Longman, 1959) and linear meter drift. Each relative-gravity survey included a minimum of two measurements at each station and a minimum of three measurements at a designated reference station. Repeat surveys allowed for monitoring of survey drift. Additional measurements were made where survey drift was found to be non-linear. Final surveys generally resulted in a standard deviation of $6 \mu \mathrm{Gal}$ or less in the gravity differences among stations.

Six microgravity surveys were completed on transects 1 , 2, and 3, from September 2009 to May 2011; five microgravity surveys were completed on transect 4 from December 2009 to May 2011 (fig. 8; see appendix table 1-4). Gravity stations along transects were named by using the convention T\#S\#, where the number following $\mathrm{T}$ is the transect number, and the number following $\mathrm{S}$ is the station number. At each transect, $\mathrm{S} 1$ is the northern-most station. Station T4S4 was inaccessible during the March 2010 survey because of ponded water following a large precipitation event. The gravity monument at T2S1 was destroyed by machinery following the March 2010 survey. Three absolute gravity measurements were made near well AAC-17 between May 2010 and May 2011.

Locations of microgravity stations were determined by using Trimble GPS equipment with data collected in "Fast Static" mode. Base station locations were occupied for greater than 2 hours and other stations were occupied concurrently for greater than 20 minutes. Collected data were processed by using Trimble Business Center software using the Yuma, Arizona and Blythe, California, Continuously Operating Reference Stations. GPS data were collected during the first gravity measurements at a site (September and December 2009) and approximately 1 year later (November 2010).

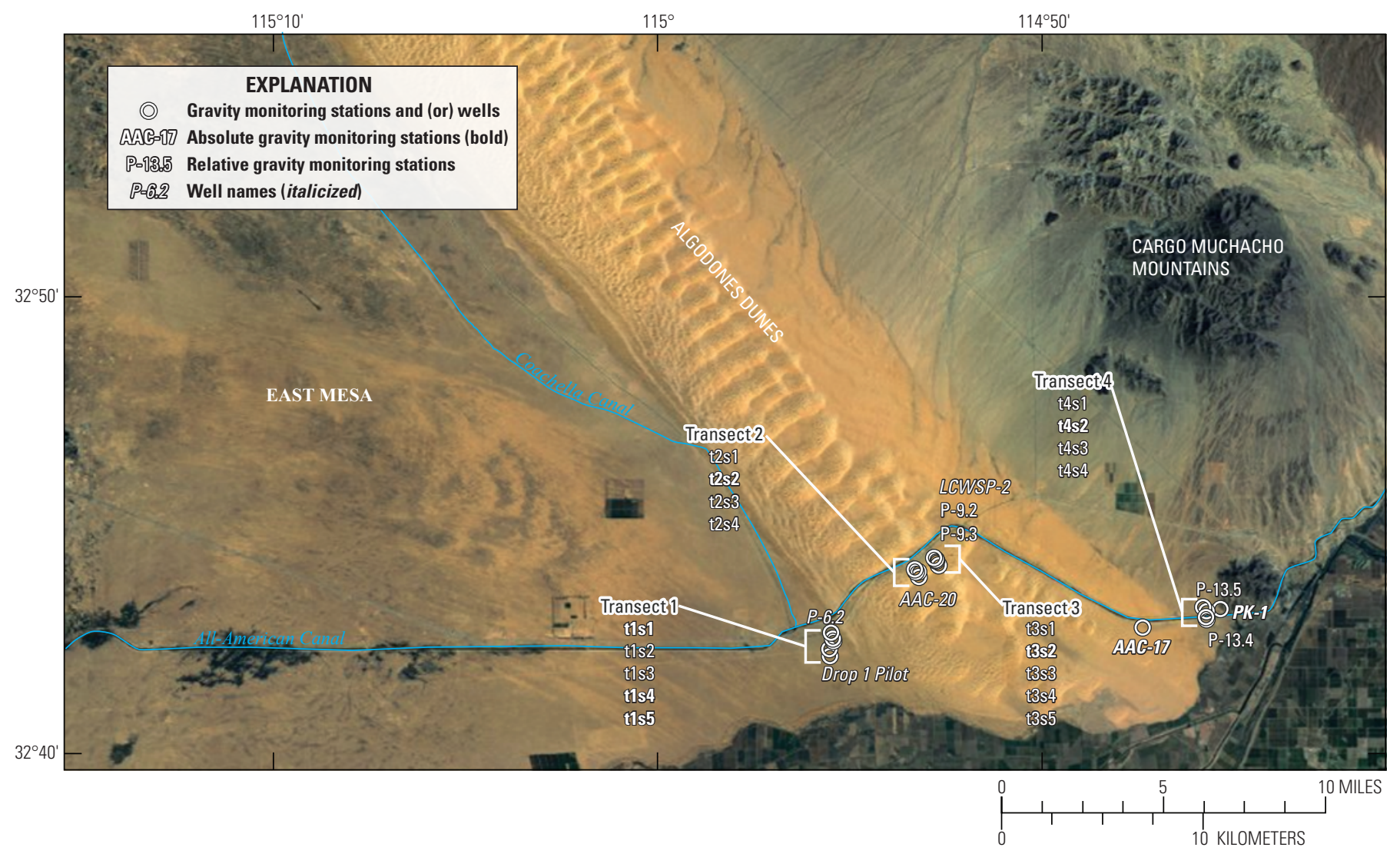

Figure 8. Microgravity network (labelled in bold lettering) and monitoring-well (unfilled circles) locations, Imperial Valley, California. 
Large changes in groundwater storage can result in subsidence of the land surface (Galloway and others, 1999). Because microgravity changes with changes in landsurface elevation, subsidence must be taken into account in gravity measurements. Results of a repeat GPS survey in November 2010 showed negligible change in land-surface elevation at the gravity monuments during the first year of gravity measurements (see appendix table 1-5). At all but one station, the change in elevation of the gravity monument between 2009 and 2010 was within the error of the GPS measurement (see appendix table 1-5). The elevation at one station (T2S4) decreased slightly more than the combined error of each GPS survey. At all stations in transects 2-4, elevation decreased slightly between 2009 and 2010, whereas elevation at all stations in transect 1 increased slightly.

Changes in the volume of water in the AAC between gravity measurements can affect the gravity at nearby stations. Gravity measurements represent a snapshot in time at each site, so the amount of water in the canal at the time of gravity measurement is important, rather than the fluctuations between measurements. The range of daily mean discharge values at AAC downstream from Pilot Knob Wasteway during gravity measurements was 1,730 to 5,430 cubic feet per second $\left(\mathrm{ft}^{3} / \mathrm{s}\right.$; table 1). The maximum gravity change due to the maximum daily mean water-level change (gage height change) in the canal of $5.1 \mathrm{ft}$ (between December 2009 and May 2010) would be 0.52 microgals ( $\mu$ gal). The effect of water-level changes in the canal on the microgravity value was within the range of error of the instrument, so no adjustments were needed.

Table 1. Daily mean discharge and gage height in the All American Canal below Pilot Knob Wasteway (station 09527500) during gravity measurements.

[mm/dd/yyyy, month, day, year; cfs, cubic feet per second; ft, feet]

\begin{tabular}{ccc}
\hline $\begin{array}{c}\text { Date } \\
\text { (mm/dd/yyyy) }\end{array}$ & $\begin{array}{c}\text { Daily mean discharge } \\
\text { at station } \mathbf{0 9 5 2 7 5 0 0} \\
\text { (cfs) }\end{array}$ & $\begin{array}{c}\text { Daily mean } \\
\text { gage height } \\
\text { (ft) }\end{array}$ \\
\hline 9/9/2009 & 4,040 & 5.67 \\
$12 / 8 / 2009$ & 1,730 & 2.51 \\
$3 / 15 / 2010$ & 4,460 & 6.20 \\
$5 / 25 / 2010$ & 5,430 & 7.61 \\
$11 / 10 / 2010$ & 4,230 & 5.91 \\
\hline
\end{tabular}

\section{Groundwater Hydrology and Quality}

Pre-AAC groundwater elevations (prior to 1940), the changes in post-construction groundwater elevations from AAC leakage (1940-2006), and more recent changes in groundwater elevations after lining the AAC lining (2007-11) were determined from previously published and historical groundwater-elevation data and recently collected groundwater-elevation data. Recent aquifer-storage change was monitored by using repeated microgravity surveys. Previously published and newly collected water-quality data were analyzed to provide information about the quality of groundwater in the study area. Previously published and newly collected stable isotope, tritium, and carbon-14 data were analyzed to provide information about the source and age of groundwater in the study area. Time-domain electromagnetic data were analyzed to examine groundwater salinity with depth and distance from the canal. Coupled water-quality and wellbore-velocity data were analyzed to provide information about water-quality changes with depth.

\section{Historic Steady-State Conditions (Pre-1940)}

\section{Groundwater Elevations and Movement}

Prior to 1940, the AAC was not carrying water, and groundwater pumping was minimal in the study area; the groundwater system is considered to have been in steadystate conditions. Groundwater elevations prior to 1940 were measured in 23 wells in the study area (fig. 9A; http://waterdata.usgs.gov/nwis; Loeltz and Leake, 1979). Groundwater elevations ranged from more than $100 \mathrm{ft}$ on the east side of the study area near the Cargo Muchacho Mountains and Pilot Knob to 10-20 ft on the west side of the study area near Imperial Valley. The groundwater elevation in the vicinity of the future LCWSP wells was approximately $80 \mathrm{ft}$ (120 ft bls; Loeltz and Leake, 1979). Groundwater movement generally was from east to west, and groundwater was recharged primarily by underflow through alluvial deposits between the Cargo Muchacho Mountains and Pilot Knob (Loeltz and others, 1975; Harshbarger, 1977); alluvial sediments in this area fill a roughly symmetrical trough that has a maximum depth of $1,350 \mathrm{ft}$ bls at its center between the two basement outcrops (Mattick and others, 1973). 

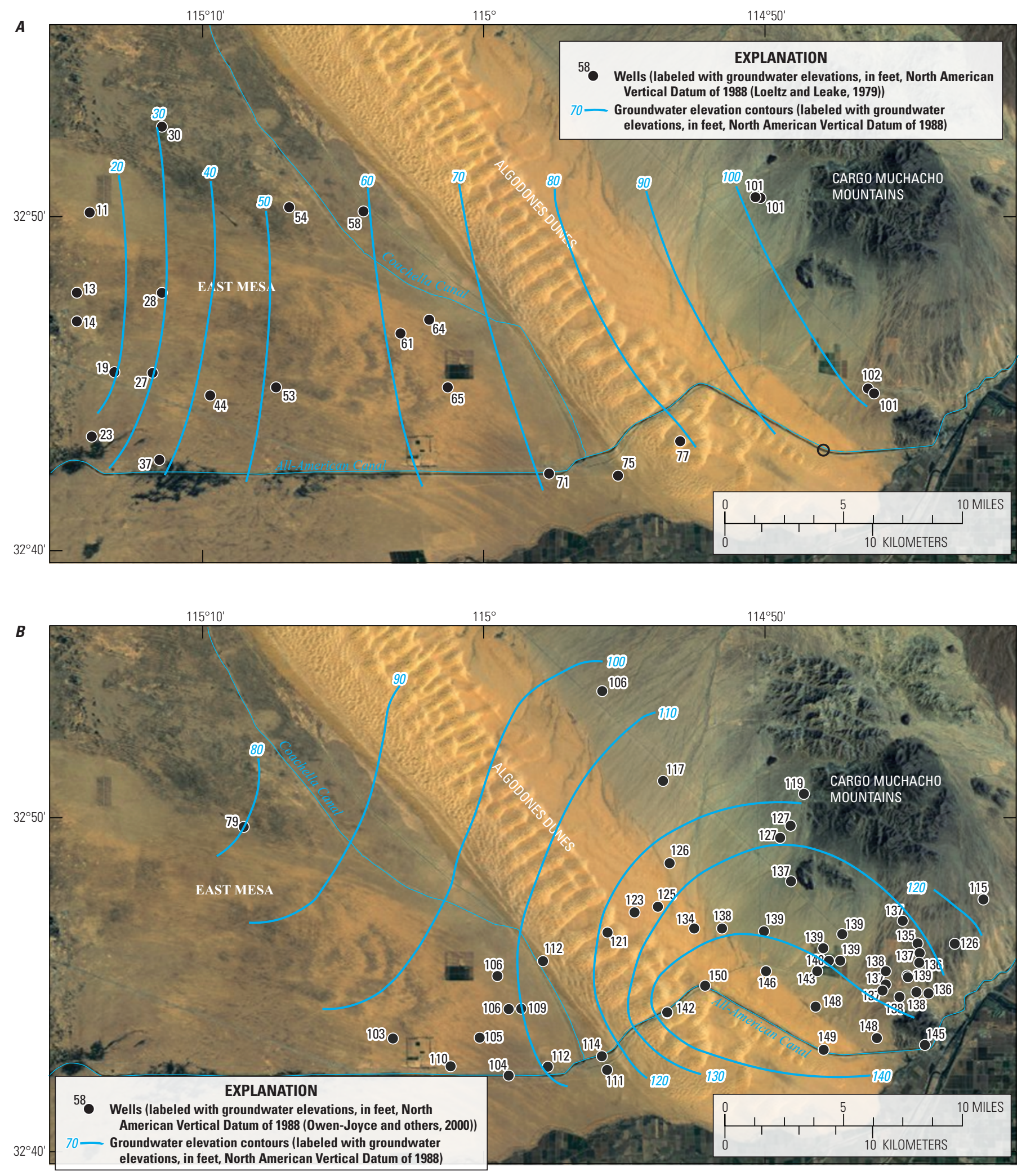

Figure 9. Map showing groundwater-elevation contours, in feet, and locations of measurements, Imperial Valley, California: $A, 1931-40 ; B, 1998-99 ; C$, November 2009; D, September 2011. 

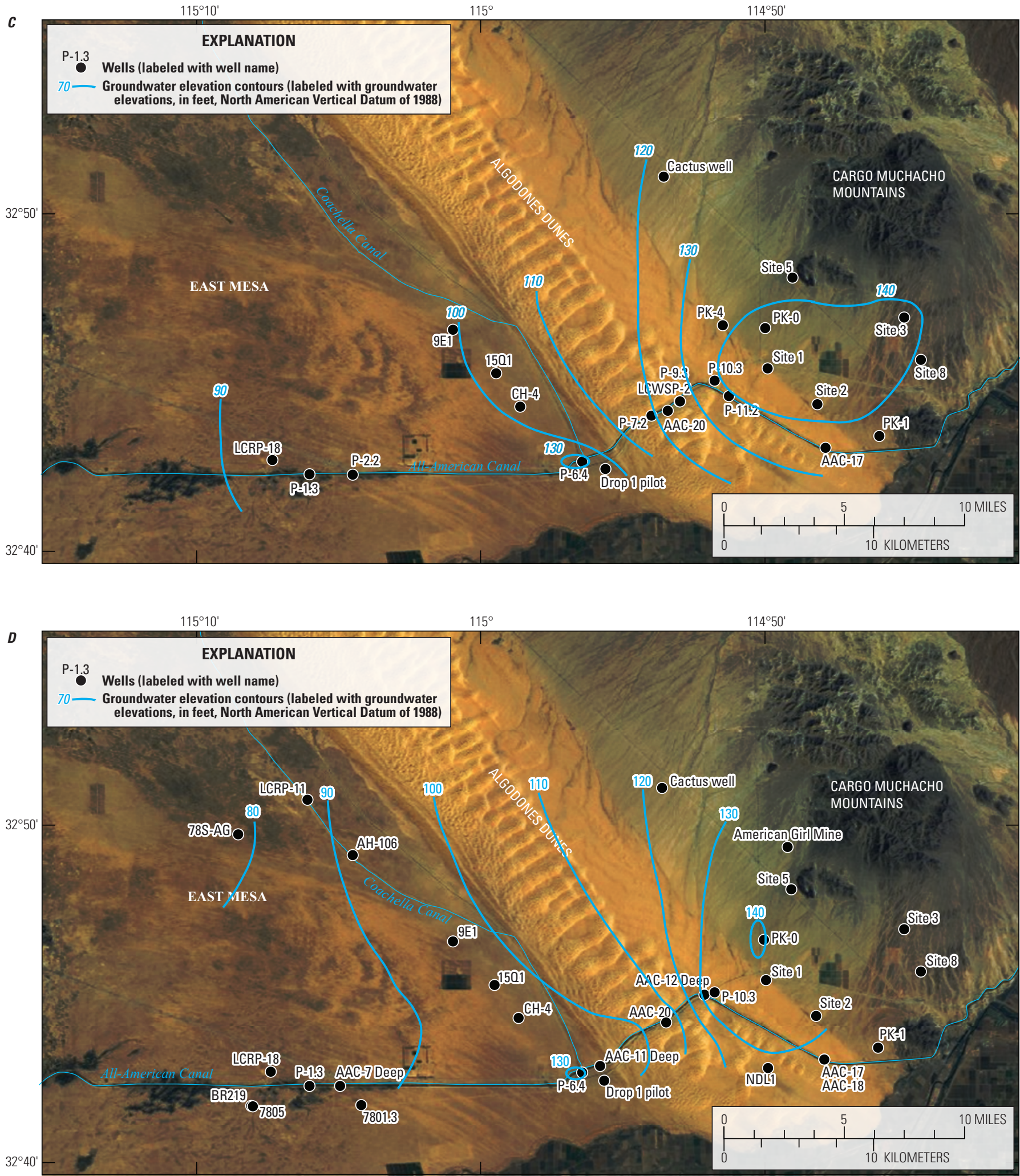

Figure 9. - Continued 


\section{Groundwater Quality}

Four groundwater-quality samples collected from four wells from 1936 to 1941 were available to help define historic groundwater-quality conditions in the study area prior to the effects of canal construction (figs. 10A, 11A;

http://waterdata.usgs.gov/nwis). It was assumed that groundwater quality samples collected in 1941 are indicative of historic conditions, even though the AAC began carrying water in October 1940. Three samples were collected from three wells in the southern part of the study area next to the future AAC. These data were plotted on trilinear diagrams (fig. 11A); the position of a sample on the diagram indicates the water type, based on the dominant cations and anions, and allows comparison among different samples. Groundwater from these wells was generally sodium-chloride/sulfate type water that had relatively low TDS concentrations $(520-830 \mathrm{mg} / \mathrm{L})$. One sample was collected from a well at the base of the Cargo Muchacho Mountains (fig. 11A). The water from this well (015S020E23M001S) was sodium-chloride type water that had higher concentrations of chloride than the other three samples. The TDS concentration in this well was $4,900 \mathrm{mg} / \mathrm{L}$.

Meidav and Furgerson (1972) identified a spatial trend in groundwater quality, most likely indicative of steady-state conditions, spanning the study area by investigating the regional subsurface geophysical electrical-resistivity gradient. From the southeast corner of the study area, a gradual decrease in resistivity to the northwest toward the Salton Sea was identified. The resistivity gradient was believed to reflect a natural increase in the salinity of groundwater with increasing distance from the Colorado River (Meidav and Furgerson, 1972). 


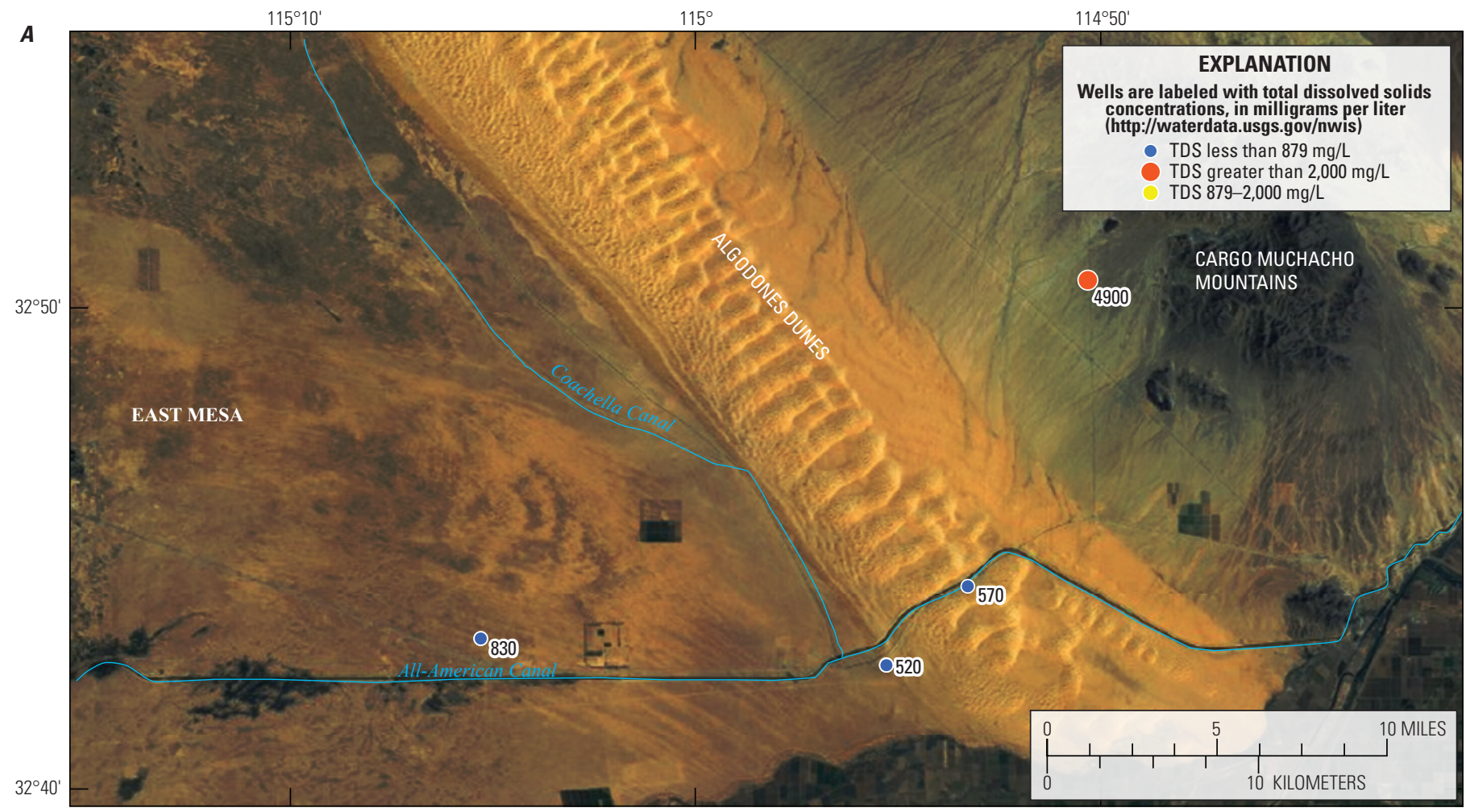

$115^{\circ} 10^{\prime}$

$115^{\circ}$

$114^{\circ} 50^{\prime}$

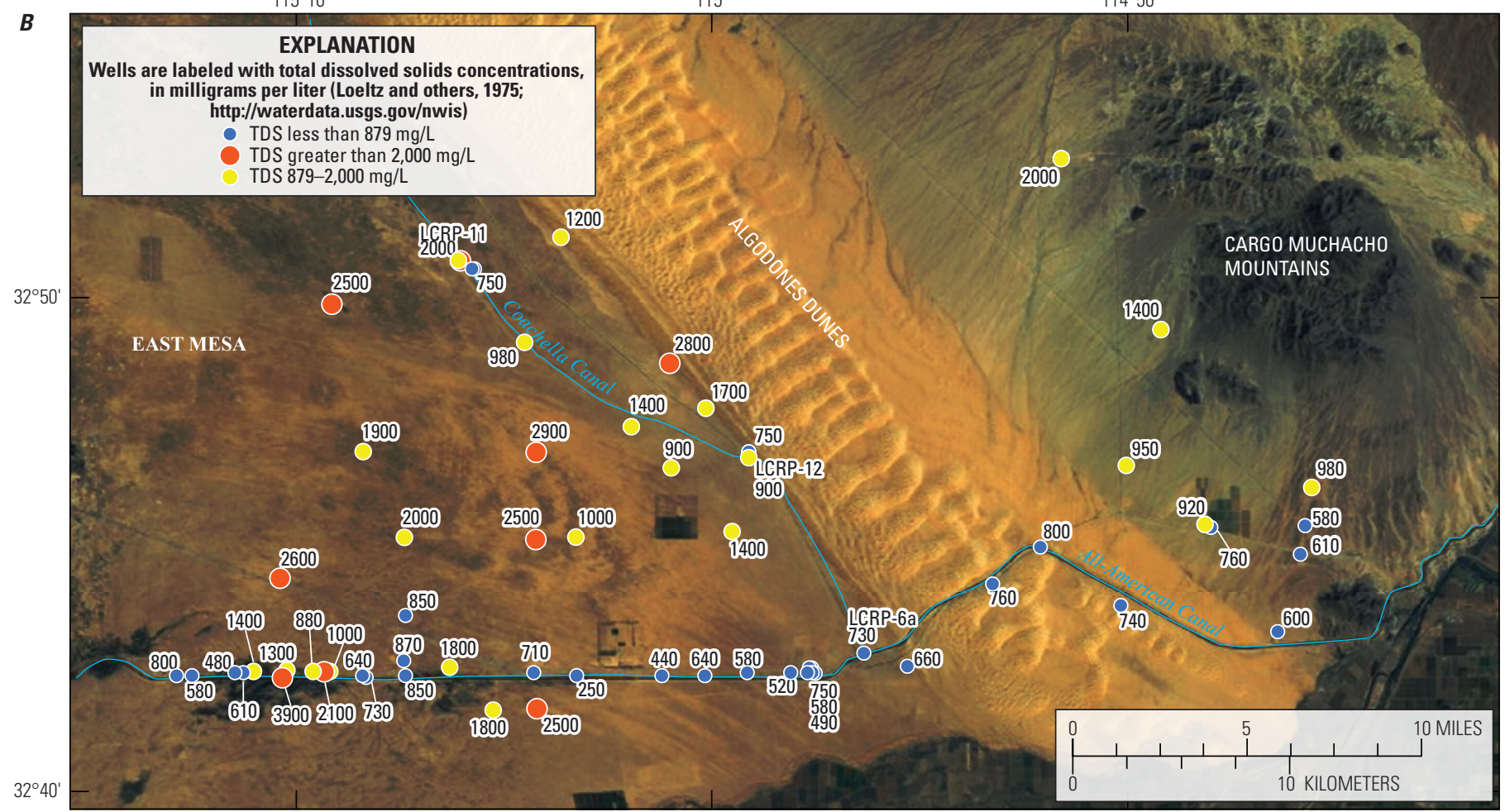

Figure 10. Total-dissolved solids (TDS) concentrations, in milligrams per liter $(\mathrm{mg} / \mathrm{L})$ in groundwater and locations of measurements, Imperial Valley, California: $A, 1917-41 ; B, 1961-65 ; C, 2007-11$. 


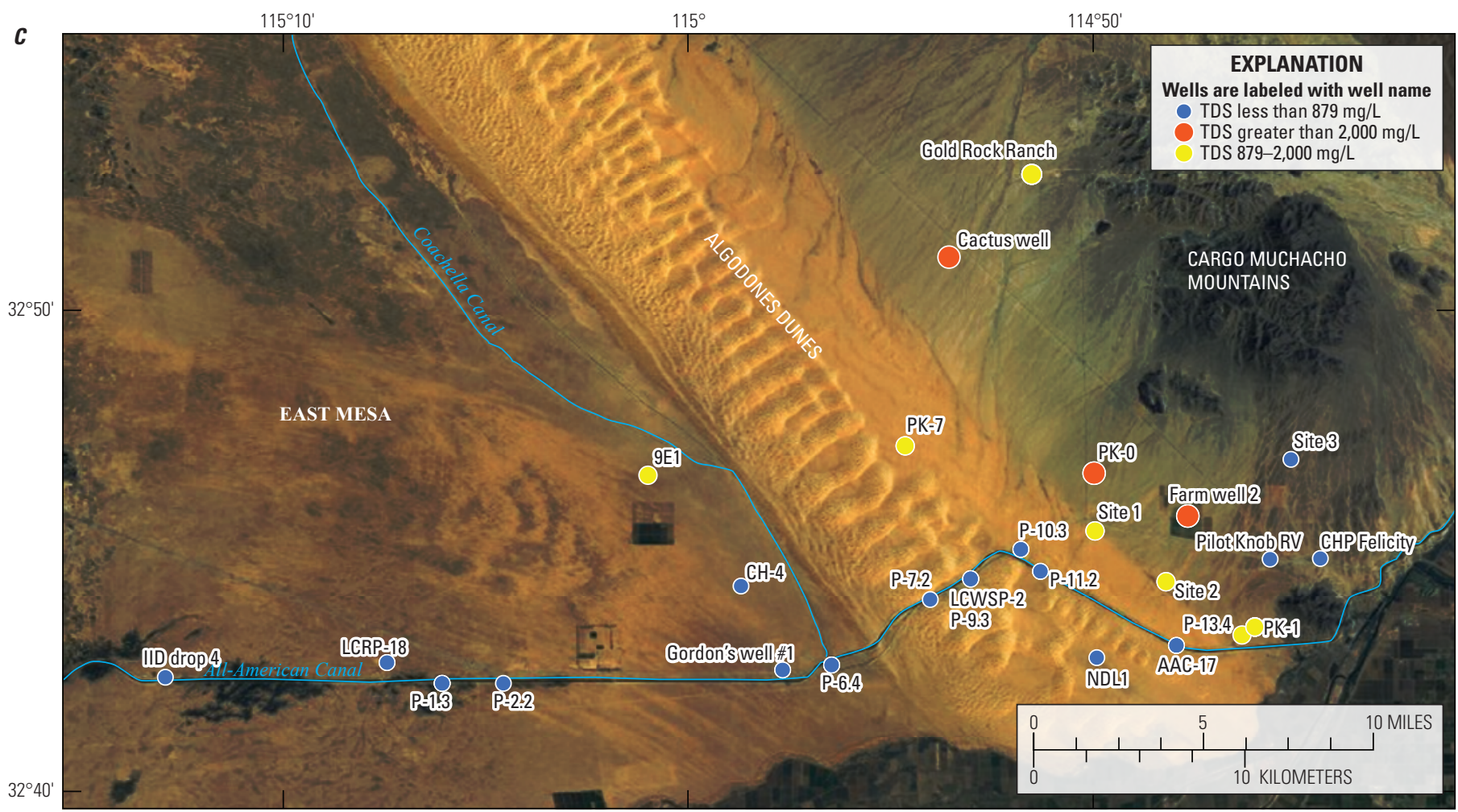

Figure 10. - Continued 


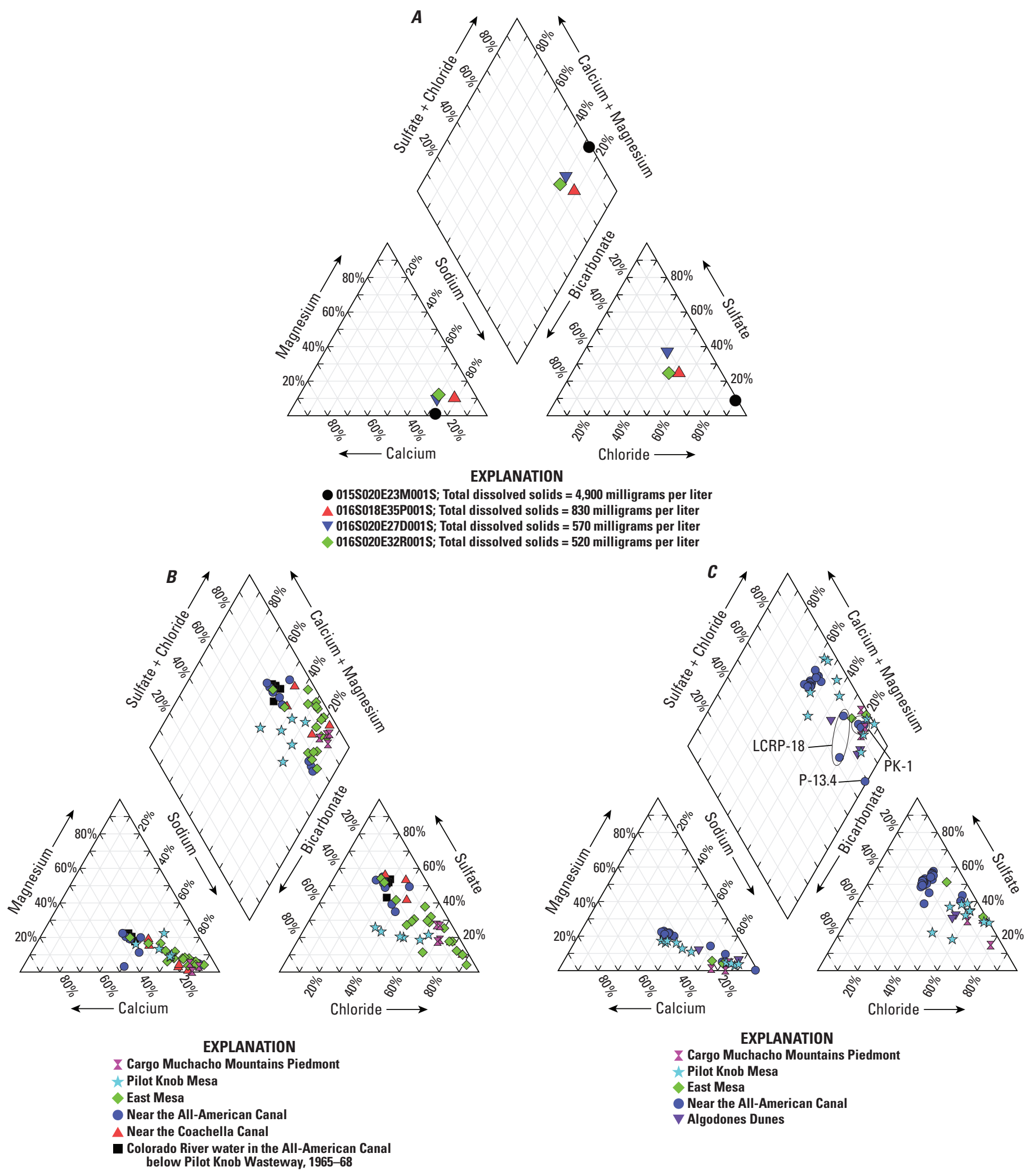

Figure 11. Groundwater quality, Imperial Valley, California: $A, 1917-41 ; B, 1961-65 ; C, 2007-11$. TDS, total dissolved solids; $\mathrm{mg} / \mathrm{L}$, milligrams per liter. 


\section{Transient Conditions (1940-2006)}

\section{Groundwater Elevations and Movement}

After construction of the AAC and Coachella Canal in the 1940 s, seepage from the canals began to affect groundwater elevations in the study area (fig. 12). By 1998-99, the years of the last extensive groundwater survey prior to canal lining, elevations had increased 40-60 ft above steady-state conditions (as represented by groundwater elevations shown in fig. $9 A$ ) along the AAC and as much as 20-30 ft to the north of the AAC in the Pilot Knob and East Mesas and the Algodones Dunes (fig. 13A). Groundwater elevations ranged from more than $140 \mathrm{ft}$ on the east end of the AAC near Pilot Knob to 80 $\mathrm{ft}$ in the East Mesa (fig. 9B). Groundwater movement was still generally from east to west; superimposed on the east to west gradient, however, was groundwater movement away from the AAC to the north and, most likely, to the south. The dominant source of recharge to upper parts of the aquifer was no longer groundwater underflow from the east, but infiltration from the $\mathrm{AAC}$ and the Coachella Canal.

By 2005, when a pre-construction groundwater survey was completed along the AAC, groundwater elevations next to the AAC had increased by as much as $40-70 \mathrm{ft}$ above steady-state conditions (fig. 14A). The groundwater elevation in the vicinity of the LCWSP wells was approximately $140-150 \mathrm{ft}$ (50-60 ft bls). Continuous groundwater-elevation data indicated that before beginning of lining the AAC, groundwater elevations in two wells within 800 and 2,500 ft of the AAC (AAC-20 and Drop 1 Pilot, respectively) fluctuated annually in direct response to the annual fluctuation of water flow in the AAC (fig. 15). Groundwater elevations in AAC-20 also fluctuated in response to pumping from the LCWSP well field. 

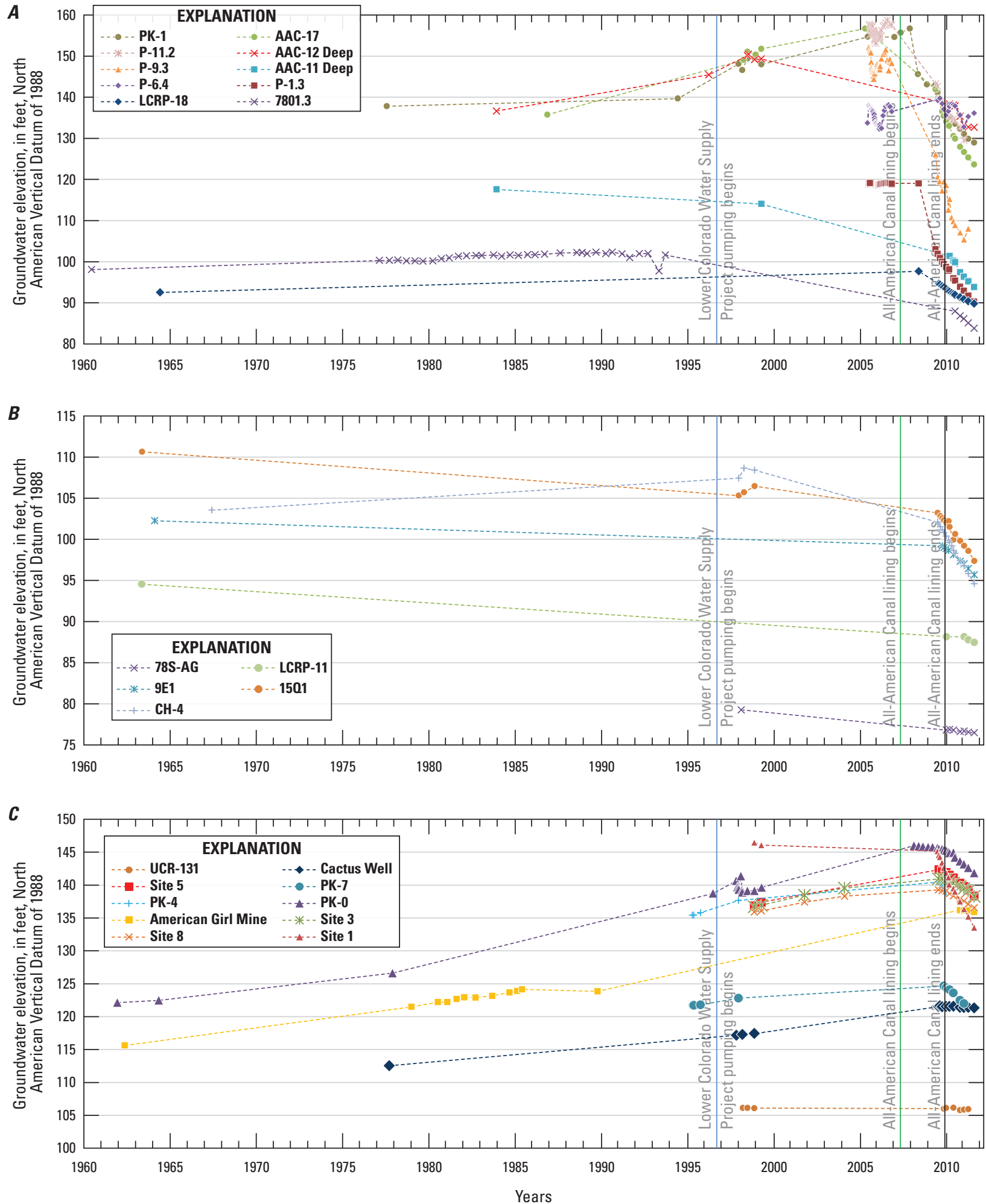

Figure 12. Groundwater elevations in selected wells, 1960-2011, Imperial Valley, California: $A$, near the All-American Canal; $B$, on the East Mesa; $C$, on the Pilot Knob Mesa and in the Algodones Dunes. LCWSP, Lower Colorado Water Supply Project; AAC, All-American Canal. 

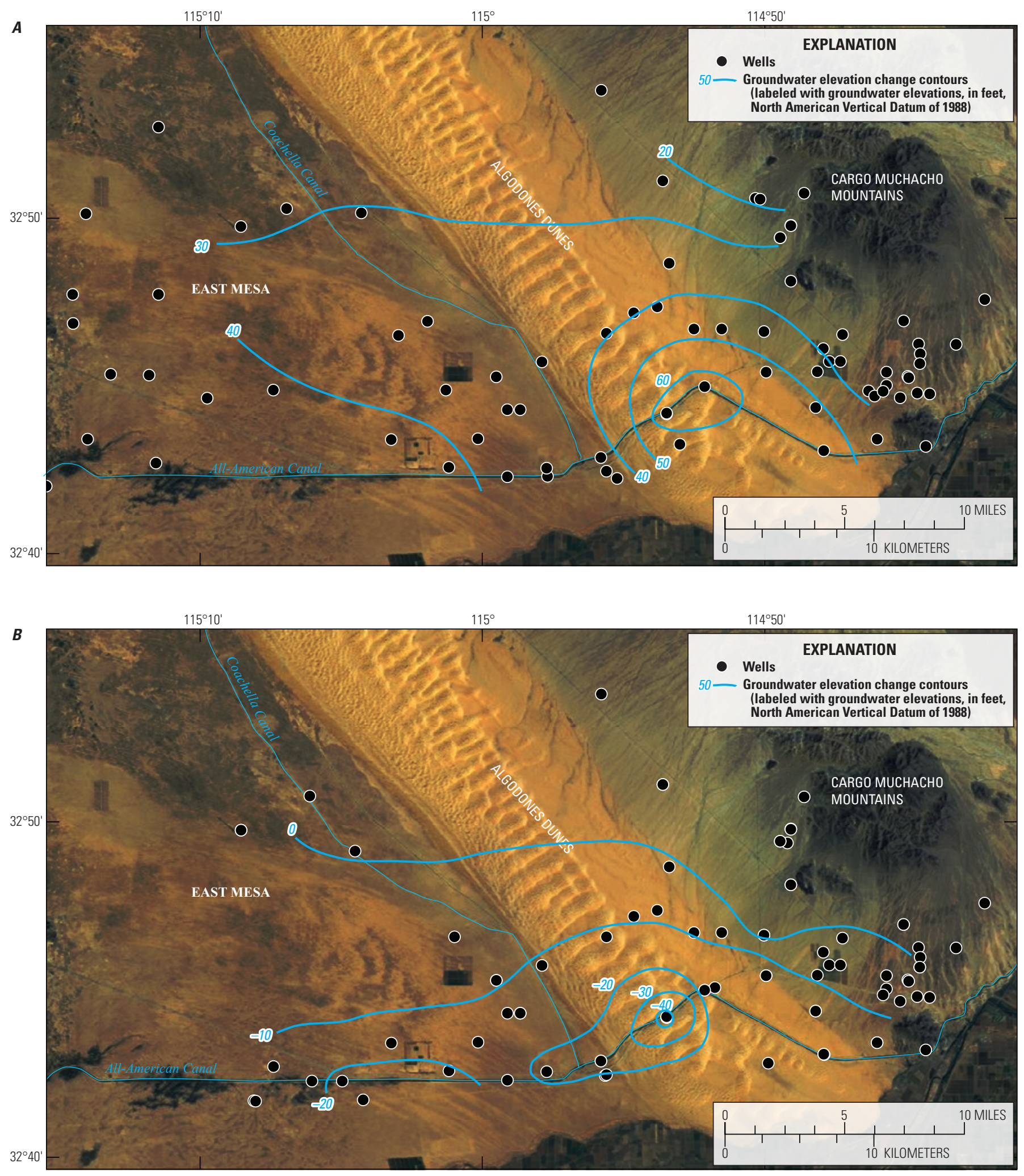

Figure 13. Groundwater-elevation change, in feet, Imperial Valley, California: $A$, from 1931-40 to 1998-99; $B$, from 1998-99 to September 2011. 

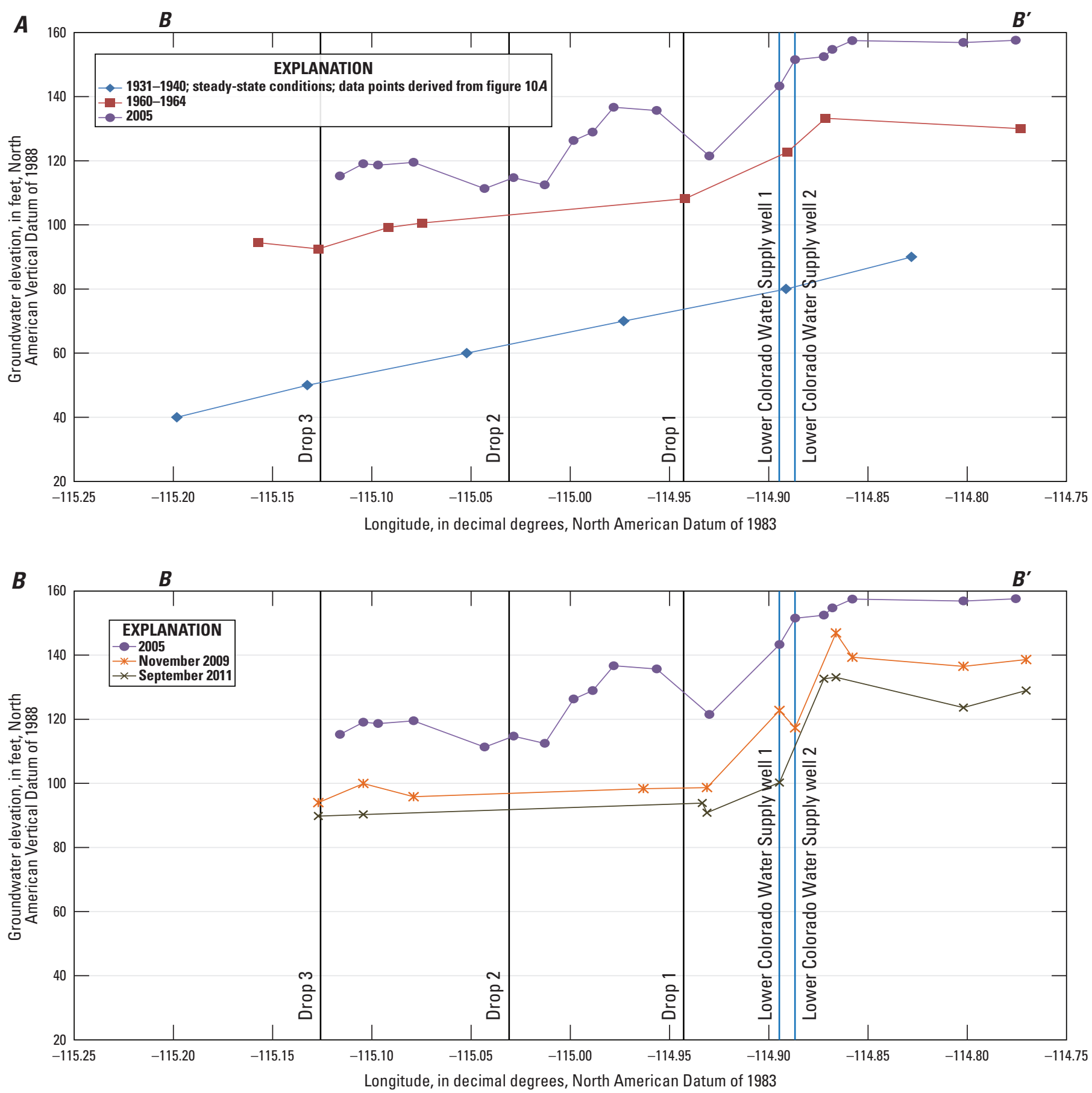

Figure 14. Groundwater-elevation change along the All-American Canal, Imperial Valley, California: $A, 1931-2005 ; B, 2005-11$. 


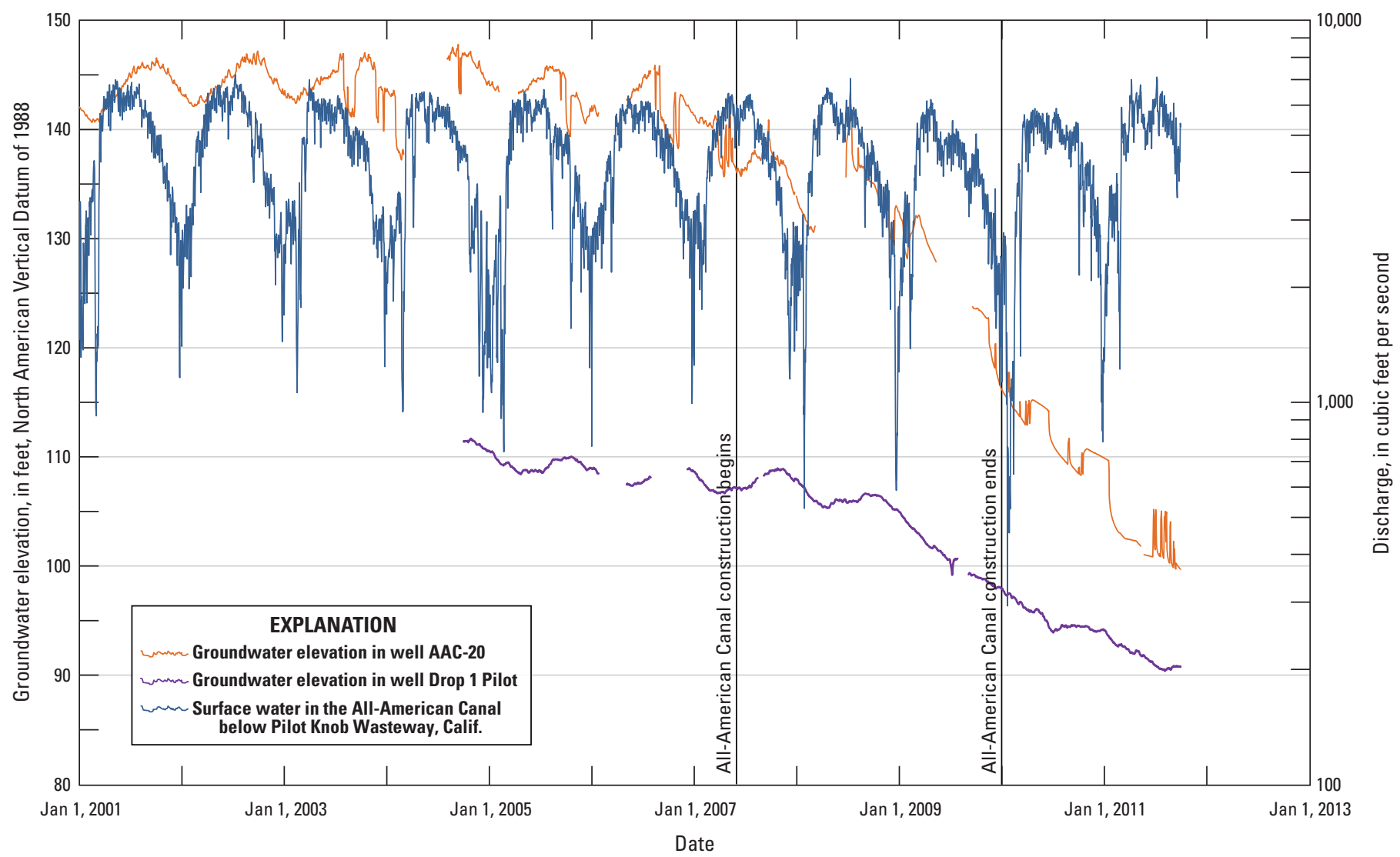

Figure 15. Continuous groundwater elevations in selected wells and surface-water discharge in the All-American Canal downstream from Pilot Knob Wasteway, Imperial Valley, California, 2001-11.

\section{Groundwater Quality}

Loeltz and others (1975) collected and analyzed a large number of groundwater-quality samples during 1961-65 and grouped water-quality data according to specific geographic areas (figs. 10B, 11B). Groundwater samples collected from wells along the Cargo Muchacho Mountains piedmont had sodium-chloride type water with TDS of 1,000-2,000 mg/L and, most likely, are indicative of historic groundwater conditions in this area. Groundwater samples collected from wells in the Pilot Knob Mesa had sodium-mixed anion type water with a TDS less than $1,000 \mathrm{mg} / \mathrm{L}$ and, most likely, were indicative of the groundwater underflow from the east (Loeltz and others, 1975). Groundwater samples collected from wells in the East Mesa and next to the AAC and Coachella Canal had a range of sodium-chloride type water to mixed cation-sulfate type water and TDS concentrations from less than $879 \mathrm{mg} / \mathrm{L}$ to close to $3,000 \mathrm{mg} / \mathrm{L}$. The variation in water-quality characteristics among these areas is most likely indicative of varying proportions of mixed cation-sulfate type recharge of Colorado River water from seepage from the AAC and Coachella Canal (represented in fig. $11 B$ as Colorado River water in the All-American Canal downstream from Pilot Knob Wasteway, 1965-68) and of water representing historic groundwater-quality conditions.

Loeltz and others (1975) investigated groundwater quality at depth in the early 1960s, including logging three deep wells, and determined that depths to brackish water varied among wells. The electrical resistivity log from the test hole of LCRP-6a, at the intersection of the AAC and the Coachella Canal (fig. 10B), indicated fresh water (specific conductance less than 3,000 microsiemens per centimeter, or $\mu \mathrm{S} / \mathrm{cm}$ ) to the total well depth of 2,519 ft bls (Loeltz and others, 1975). The electrical resistivity log for the test hole of LCRP-12, 5.5 mi northwest of LCRP-6a (fig. 10B), indicated fresh water to $1,000 \mathrm{ft}$ bls (Loeltz and others, 1975). The electrical resistivity $\log$ for the test hole of LCRP-11, $13 \mathrm{mi}$ northwest of LCRP-6a (fig. 10B), indicated fresh water to $250 \mathrm{ft}$ bls and brackish water (specific conductance greater than $3,000 \mu \mathrm{S} / \mathrm{cm}$ ) from 250 to $1,140 \mathrm{ft}$ bls, (Loeltz and others, 1975). 


\section{Recent Conditions (2007-11)}

\section{Groundwater Elevations and Movement}

During and after lining the AAC (2007-10), groundwater elevations began to steadily decrease in most of the monitored wells in the study area (fig. 16). By September 2011, elevations had decreased by about 10-40 ft below 1999 conditions along the AAC and as far as $7 \mathrm{mi}$ north of the AAC (fig. 13B). Groundwater-elevation data from 1999 (the most recent year in the transient conditions period that had good spatial coverage) were used to compare pre-lining conditions in the study area to those after lining the canal because groundwater elevations measured during the preconstruction survey in 2005 were primarily along the AAC and did not provide sufficient coverage farther from the AAC. Along the AAC, groundwater elevations decreased by about 20-40 ft between the 2005 pre-construction survey and the September 2011 survey (fig. 14B). In September 2011, the groundwater elevation in the vicinity of the LCWSP wells was approximately $100 \mathrm{ft}(70 \mathrm{ft}$ bls $)$. The area surrounding the LCWSP well field showed the greatest decreases because seepage recharge from the AAC was mitigated, yet pumping from these wells continued. Groundwater elevations at the eastern and western ends of the AAC, near Pilot Knob and Drop 3, respectively, decreased by about $30 \mathrm{ft}$ from 2005 to 2011 (fig. 14B). The continuous groundwater elevations measured at Drop 1 Pilot and AAC-20 no longer fluctuated on an annual cycle after lining the AAC and have shown a steady decrease since about mid-2008 (fig. 15). Continuous groundwater elevations measured in AAC-20, however, continued to fluctuate on a shorter time frame because AAC-20 is affected by pumping from the LCWSP well field.

Wells AAC-12 Deep and P-6.4 (fig. 3) are near the two relatively small, unlined sections of the AAC where it crosses Interstate 8 . Although these wells have only been measured since 2009-10, groundwater elevations in these areas have not decreased by as much as in other areas along the AAC (figs. 9C-D, 16A), and they fluctuate on an annual cycle in direct response to the annual fluctuation of surface-water flow in the AAC. The localized areas of smaller declines in groundwater elevations near the unlined sections of the AAC are not directly indicated on the 1999-2011 water-level change map (fig. 13B) because no 1999 water-level data were available for these areas. Well P-6.4 is a shallow well, perforated from 35 to $45 \mathrm{ft}$ and had water levels 19-23 ft below land surface; groundwater elevations in this well could also indicate a localized perched zone in this area. Lacustrine deposits have been mapped at land surface about $0.2 \mathrm{mi}$ north of this well; it is possible these deposits exist beneath this well (Loeltz and others, 1975, plate 1). None of the other shallow wells along the AAC had groundwater elevations as close to land surface.
In November 2009 and September 2011, the beginning and end of the data-collection period for this study, groundwater elevations ranged from more than $140 \mathrm{ft}$ on the east side of the study area to $80 \mathrm{ft}$ on the northwestern side of the study area (figs. 9C-D). By September 2011, groundwater movement generally had returned to a primarily east-to-west flow direction as the seepage recharge from the AAC was mitigated, and the groundwater mound dissipated. It appears, however, that groundwater in the southeastern part of the study area also flows to the south and southwest, on the basis of groundwater-elevation data available north of the international border (fig. 9D).

\section{Groundwater-Storage Change}

Microgravity values measured at all sites, except station T2S4, decreased between the first and last measurements (fig. 17; see appendix table 1-4), indicating a generalized decrease in groundwater storage between September 2009 and May 2011. Individual stations showed variability in the magnitude and direction of microgravity change at shorter intervals throughout the monitoring period. The largest decreases in microgravity values and groundwater elevations were observed at stations T2S2 (fig. 17B) and T3S2 (fig. 17C), near pumping wells LCWSP-1 and 2, respectively (fig. 8).

Eight of the gravity measurement stations were at wells where groundwater elevations were being monitored (fig. 8). Three of the wells went dry during the study period (wells P-6.2, P-13.4, P-13.5), but microgravity monitoring continued at these stations. At station T1S5 (fig. 17A), co-located at the Drop 1 Pilot well, microgravity values decreased until March 2010, then increased, and then decreased again. Recharge through the unlined section of the AAC where Interstate 8 crosses the canal, and the associated groundwater mound in this area, could be affecting microgravity measurements along transect 1 . At the T2S2 station, $515 \mathrm{ft}$ directly north of observation well AAC-20 and near pumping well LCWSP-1, microgravity values decreased during the first three measurements, then rose slightly between March and May 2010, and then decreased for the subsequent measurements (fig. 17B). Pumping well LCWSP-1 was off for most of April and May 2010, correlating with the groundwater-elevation rise and the positive microgravity change. Gravity station T3S2 was co-located with pumping well LCWSP-2 and the two monitoring wells P-9.3 and $\mathrm{P}-9.2$. The microgravity values at T3S2 decreased between September 2009 and March 2010, which was followed by a slight increase at the May 2010 measurements (fig. 17C). Well LCWSP-2 was pumping almost continually during the microgravity data collection period; the positive microgravity change at T3S2 in May 2010 could be related to the lack of pumping during this period at the nearby LCWSP-1 well. 

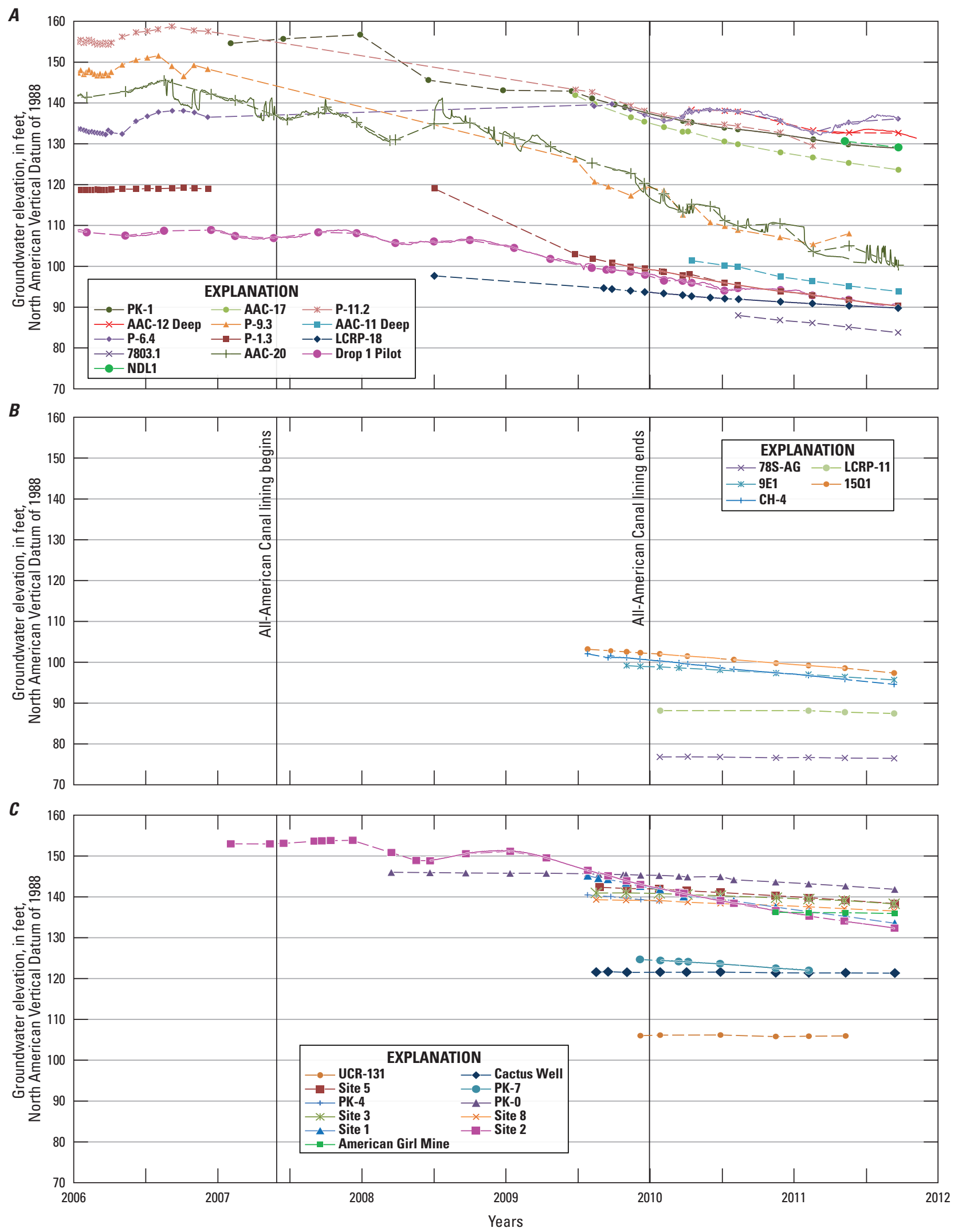

Figure 16. Groundwater elevations in selected wells, Imperial Valley, California: $A$, near the the All-American Canal, 2006-11; $B$, on the East Mesa, 2009-11; C, on the Pilot Knob Mesa and in the Algodones Dunes, 2007-11. 

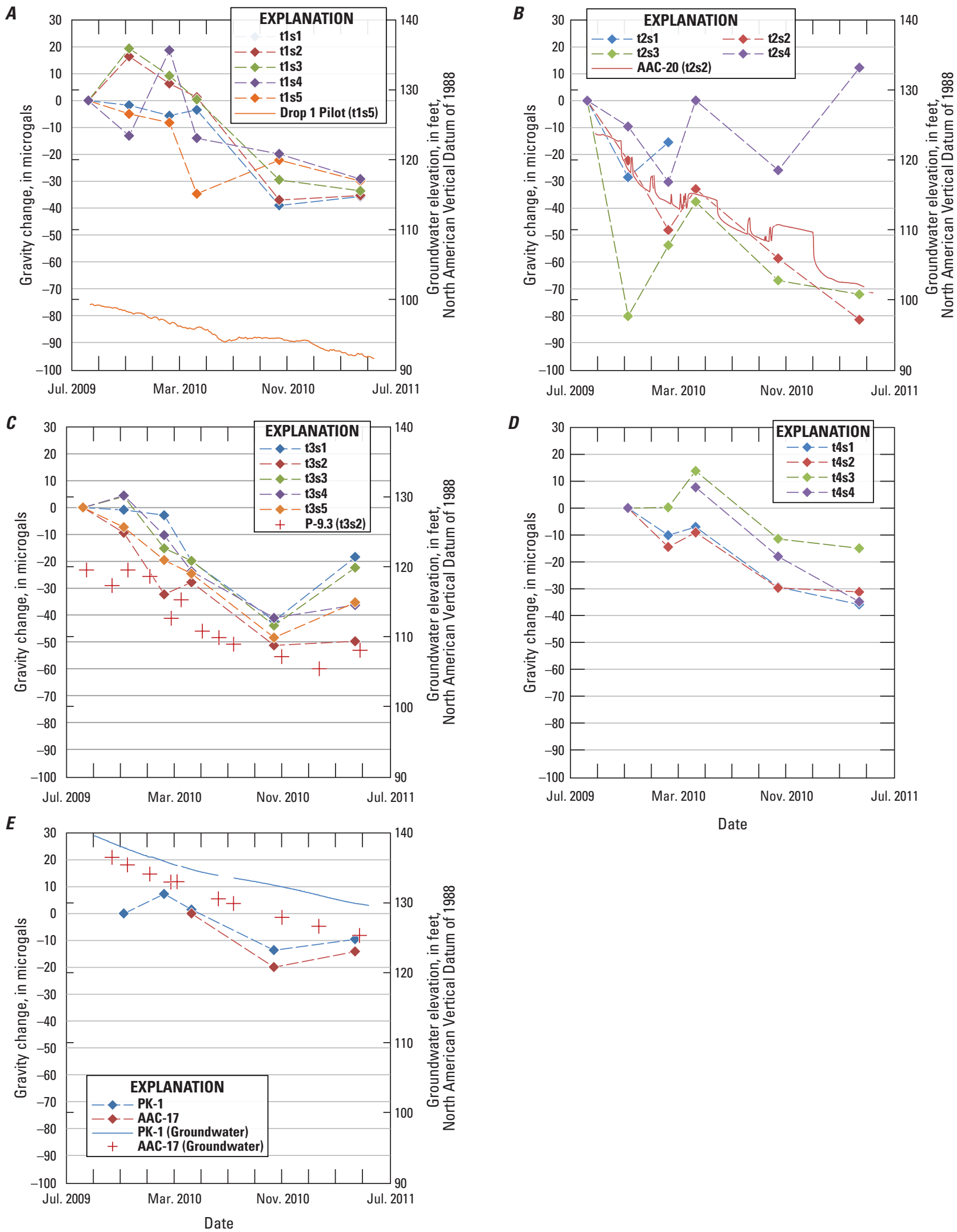

Figure 17. Gravity change and groundwater-elevation change, 2009-11, Imperial Valley, California: $A$, transect 1; $B$, transect 2; $C$, transect $3 ; D$, transect $4 ; E, P K-1$ and AAC-17. 
Absolute microgravity measurements taken at all of the stations on transect 4 and at well PK-1 showed a positive change between March and May 2010 and, then, negative changes until the final reading (figs. 17D-E). Microgravity values decreased following the first measurement at the gravity station at well AAC-17 in May 2010, then rose slightly, while the groundwater elevation decreased throughout the period of measurement. In January 2010, there was a 3-in. rainfall over 3 days. Overland flow into the AAC at transect 4 was observed to be impeded by a mound of sand that was likely to have been produced during the lining of the AAC; runoff ponded at the southern end of transect 4. Station T4S4 was completely submerged, and station T4S3 was also likely to be submerged, as indicated by the presence of mud cracks. The ponded water was observed from late January 2010 into March 2010. The mass of the ponded water at the surface, and most likely in the unsaturated zone, influenced the March and May 2010 microgravity measurements at transect 4 and at PK-1.

Linear regression between the microgravity change and groundwater-elevation change in wells was used to estimate specific yield at four pairs of gravity stations and wells (table 2; well PK-1 was excluded because of the effect of ponded water). Specific yield at each well was estimated by the ratio of change in the microgravity-based estimate of stored water to the measured change in groundwater elevation. The microgravity change was converted to an equivalent thickness of change in water stored in the subsurface by using the infinite slab approximation of 12.77 microgals per foot $(\mu \mathrm{gal} / \mathrm{ft})$ of water (Pool and Eychaner, 1995). Good positive correlation between microgravity and groundwater-elevation change was indicated by correlation coefficients of 0.94 or greater at two of the four sites; poor to moderate positive correlation was indicated by correlation coefficients of 0.56 and 0.64 at the remaining two sites. Estimates of specific yield at the individual sites ranged from 0.18 to 0.34 ; this range of values overlaps with reported specific yields for fine sand (0.21), coarse sand (0.27), and dune sand (0.38; Johnson, 1967).

\section{Groundwater Sources and Ages}

Samples were analyzed for the stable isotopes of hydrogen $\left(\delta^{2} \mathrm{H}\right)$ and oxygen $\left(\delta^{18} \mathrm{O}\right)$ to determine sources of water to wells and to evaluate the movement of water in the study area (see appendix table 1-2). The linear relation between $\delta^{2} \mathrm{H}$ and $\delta^{18} \mathrm{O}$ in natural precipitation is referred to as the global meteoric water line (Rozanski and others, 1993). As described in the "Methods of Investigation" section, the $\delta^{18} \mathrm{O}$ and $\delta^{2} \mathrm{H}$ composition of groundwater, relative to the global meteoric water line and the isotopic composition of water from other sources, can be an indicator of the source of groundwater recharge.

Selected samples were analyzed for the radioactive isotopes of hydrogen (tritium, ${ }^{3} \mathrm{H}$ ) and carbon $\left({ }^{14} \mathrm{C}\right)$ to determine the age, or time since recharge, of the groundwater. As described in the "Methods of Investigation" section, ${ }^{3} \mathrm{H}$ was used to trace the movement and relative age of water on timescales ranging from recent to about 60 years before present (post 1953). In this report, groundwater with ${ }^{3} \mathrm{H}$ activity greater than 1 tritium unit (TU) was interpreted to be water recharged after 1953, or of recent age. The ${ }^{14} \mathrm{C}$ activities were used to determine the age of a groundwater sample on timescales ranging from recent to more than 20,000 years before present (described in the "Methods of Investigation" section).

The isotopic composition of groundwater in the study area ranged from about -50 to -114 per mil $\delta^{2} \mathrm{H}$ and about -7 to -15 per mil $\delta^{18} \mathrm{O}$ (figs. 18, 19). For comparison, the isotopic composition of "old" Colorado River water that had infiltrated in the Mexicali Valley prior to the construction of reservoirs on the river (pre-1930s) was determined by Payne and others (1979, p. 208) to be -112 per mil $\delta^{2} \mathrm{H}$ and -14.6 per mil $\delta^{18} \mathrm{O}$ (fig. 18). All of the groundwater samples from 2007 to 2011 fell below the global meteoric water line and plotted along a local evaporation line (Schroeder and others, 1991).

Table 2. Correlation of microgravity change and groundwater-elevation change, and resulting estimates of specific yield.

[ft, feet; $\mu \mathrm{gal}$, microgal. Darker shading indicates good positive correlation of groundwater elevation and microgravity change. Lighter shading indicates poor to moderate positive correlation of groundwater elevation and microgravity change]

\begin{tabular}{|c|c|c|c|c|c|c|c|}
\hline Well name & $\begin{array}{c}\text { Gravity } \\
\text { station } \\
\text { name }\end{array}$ & $\begin{array}{l}\text { Specific } \\
\text { yield }\end{array}$ & $\begin{array}{c}\text { Correlation } \\
\text { coefficient } \\
\quad\left(R^{2}\right)\end{array}$ & $\begin{array}{l}\text { Groundwater- } \\
\text { elevation change } \\
\text { (ft) }\end{array}$ & 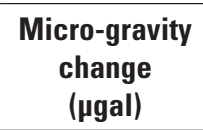 & $\begin{array}{c}\text { Number } \\
\text { of } \\
\text { measurements }\end{array}$ & $\begin{array}{l}\text { Measurement } \\
\text { date } \\
\text { range }\end{array}$ \\
\hline AAC-20 & $\mathrm{T} 2 \mathrm{~S} 2$ & 0.32 & 0.96 & -20.0 & -81.5 & 6 & September 2009-May 2011 \\
\hline P-9.3 & $\mathrm{T} 3 \mathrm{~S} 2$ & 0.34 & 0.94 & -11.5 & -49.8 & 6 & September 2009-May 2011 \\
\hline Drop 1 Pilot & T1S5 & 0.32 & 0.64 & -7.4 & -29.9 & 6 & September 2009-May 2011 \\
\hline AAC-17 & AAC-17 & 0.18 & 0.56 & -6.0 & -14.2 & 3 & May 2010-May 2011 \\
\hline
\end{tabular}




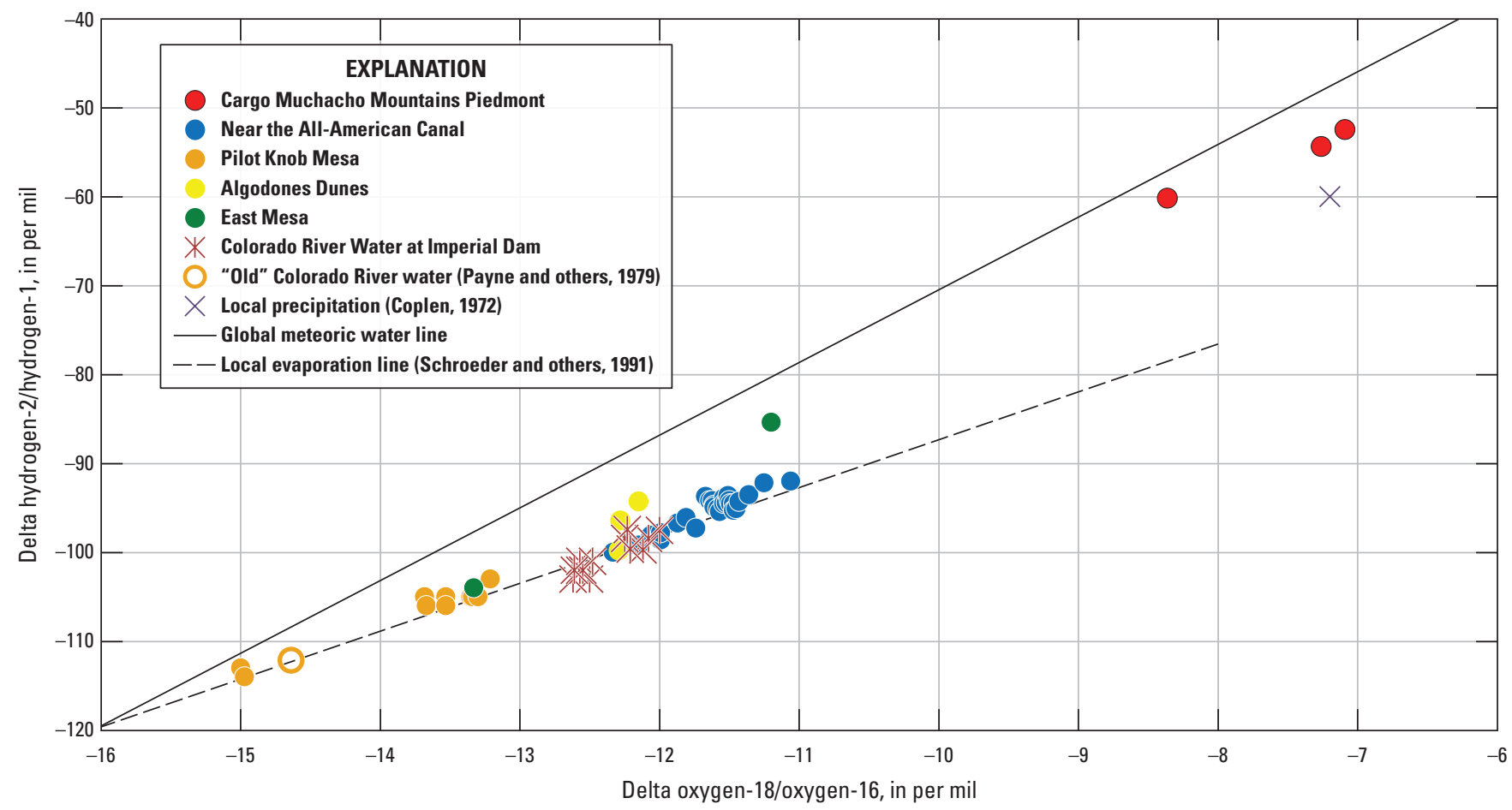

Figure 18. Delta hydrogen-2/hydrogen-1 and delta oxygen-18/oxygen-16 in groundwater, Imperial Valley, California, 2007-11.

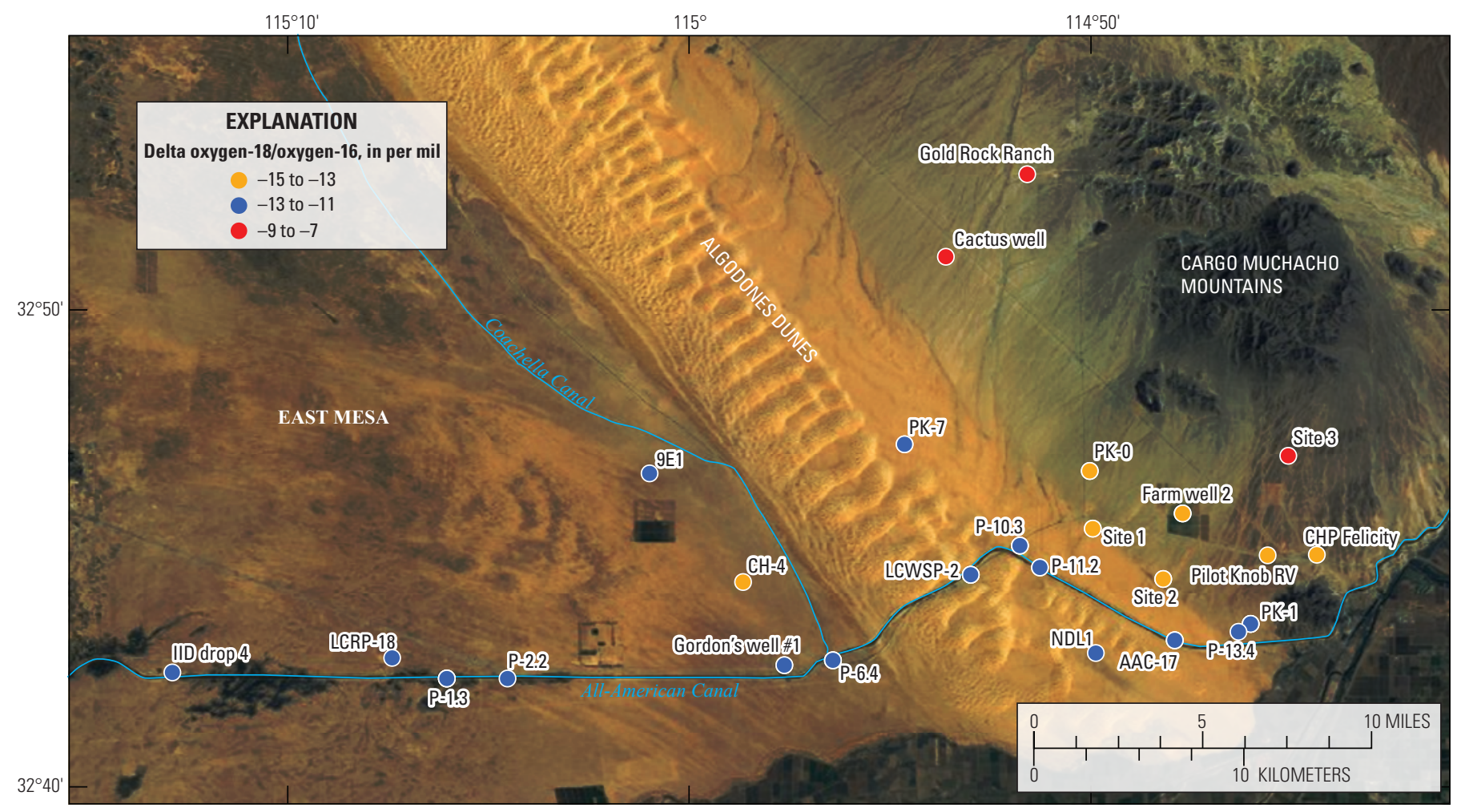

Figure 19. Delta oxygen-18/oxygen-16 in groundwater sampled from wells, Imperial Valley, California, 2007-11. 
The isotopic composition of groundwater from wells on the eastern-most part of Pilot Knob Mesa (Pilot Knob RV and CHP Felicity) was the lightest (most depleted) in the study area with -113 and -114 per mil $\delta^{2} \mathrm{H}$ and about -15 per mil $\delta^{18} \mathrm{O}$ (figs. 18, 19), similar to groundwater attributed to "old" Colorado River water by Payne and others (1979). These wells likely mostly contained historic groundwater recharged by underflow of "old" Colorado River water from the east. The ${ }^{3} \mathrm{H}$ activities in these wells were less than $1 \mathrm{TU}$ (fig. 20). The ${ }^{14} \mathrm{C}$ activity in the CHP Felicity wells was $67 \mathrm{pmC}$, which indicated an uncorrected ${ }^{14} \mathrm{C}$ age of 3,300 years.

The isotopic composition of groundwater from wells on the western part of Pilot Knob Mesa (Farm Well 2, PK-0, Site 1 , Site 2) ranged from -110 to -100 per mil $\delta^{2} \mathrm{H}$ and -14 to -13 per mil $\delta^{18} \mathrm{O}$ (figs. 18,19 ). The groundwater in these wells likely was a mixture of historic underflow from the east and more recent seepage of Colorado River water from the AAC. With the exception of groundwater from Site 2, the ${ }^{3} \mathrm{H}$ activity in groundwater from the wells on Pilot Knob Mesa was less than 1 TU (fig. 20). These data indicated that the groundwater was predominantly recharged prior to 1953 . The ${ }^{14} \mathrm{C}$ activities of groundwater from two of the three wells (PK-0, Site 1) were $39 \mathrm{pmC}$, corresponding to an uncorrected ${ }^{14} \mathrm{C}$ age of 7,700 years since the groundwater was recharged. Groundwater from well Site 2 had a ${ }^{3} \mathrm{H}$ activity of $6 \mathrm{TU}$, indicating a substantial fraction of the water recharged after 1953. The ${ }^{14} \mathrm{C}$ activity of groundwater from this well was $68 \mathrm{pmC}$, corresponding to an uncorrected ${ }^{14} \mathrm{C}$ age of about
3,300 years. The apparently divergent ages indicated by ${ }^{3} \mathrm{H}$ and ${ }^{14} \mathrm{C}$ indicated that well Site 2 yielded a mixture of recent and old recharge.

The isotopic composition of groundwater from wells along the Cargo Muchacho Mountains Piedmont (Gold Rock Ranch, Cactus Well, Site 3) was the heaviest (least depleted), -60 and -50 per mil $\delta^{2} \mathrm{H}$ and -9 and -7 per mil $\delta^{18} \mathrm{O}$ (figs. 18, 19). The isotopic data from this area plotted near the meteoric water line and indicated a different source of recharge from the rest of the study area. These stable isotope values were similar to the stable isotope value for local precipitation in the study area, reported by Coplen (1972; fig. 18). The source of recharge along the Cargo Muchacho Mountains Piedmont is most likely runoff from precipitation events. The ${ }^{3} \mathrm{H}$ activity in groundwater from these wells was less than 1 TU (fig. 20); the ${ }^{14} \mathrm{C}$ activities of groundwater from two of these wells were 9 and $14 \mathrm{pmC}$, corresponding to uncorrected ${ }^{14} \mathrm{C}$ ages of 19,500 years and 16,500 years, respectively. The ${ }^{14} \mathrm{C}$ activity of groundwater from the third well (Cactus Well), farther down the piedmont slope, was $54 \mathrm{pmC}$, corresponding to an uncorrected ${ }^{14} \mathrm{C}$ age of 5,100 years.

The isotopic composition of groundwater from wells next to the AAC ranged from -100 to -90 per mil $\delta^{2} \mathrm{H}$ and -12.5 to -11 per mil $\delta^{18} \mathrm{O}$ (figs. 18,19 ). The isotopic composition of surface water collected from 1997 to 2000 from the Colorado River upstream from Imperial Dam, about $23 \mathrm{mi}$ upstream of the AAC in the study area, ranged from -103 to -97 per mil $\delta^{2} \mathrm{H}$ and -12.6 to -12 per mil $\delta^{18} \mathrm{O}$ (fig. 18). The

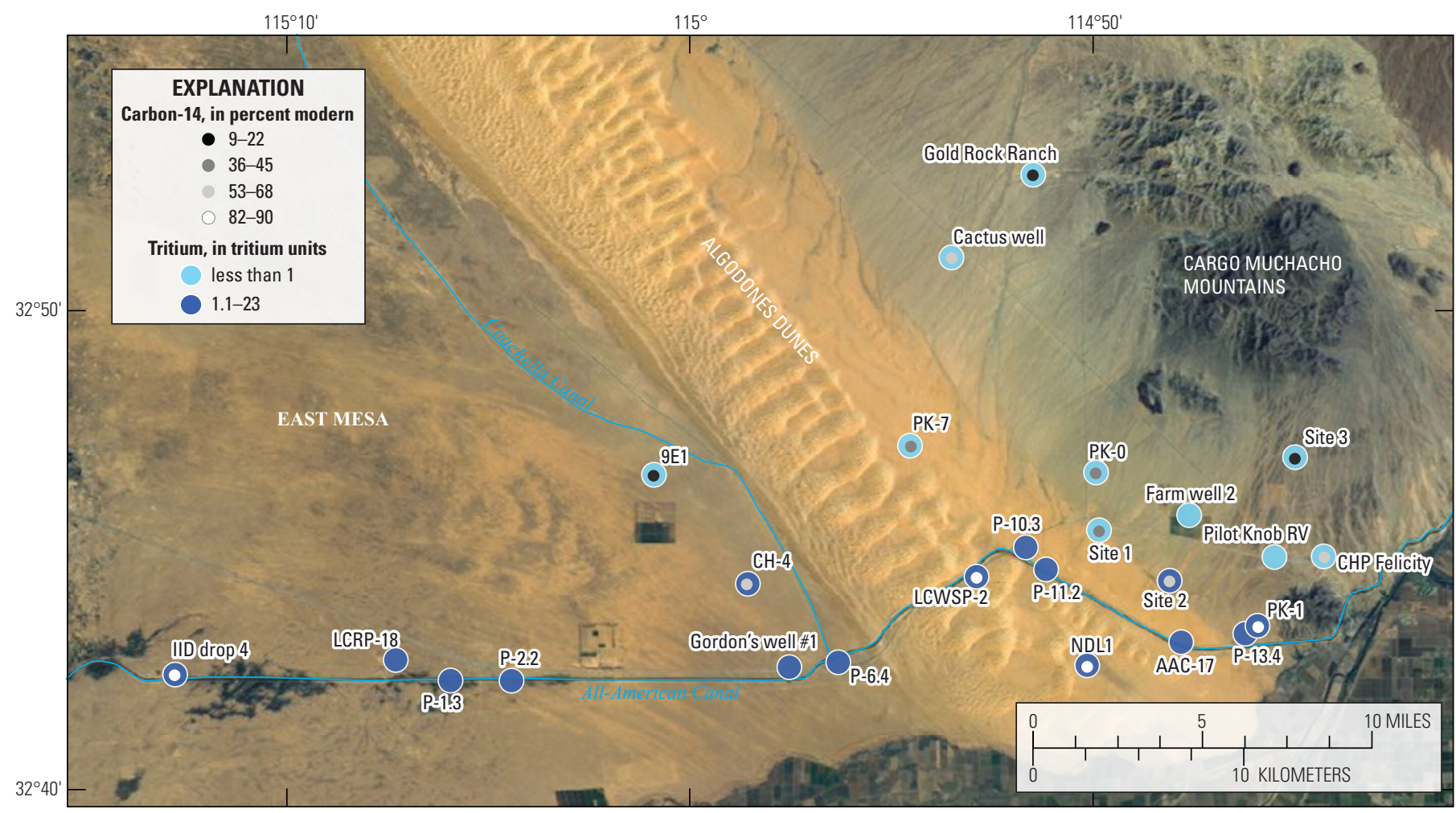

Figure 20. Tritium and carbon-14 in groundwater, Imperial Valley, California, 2007-11. 
isotopic data of groundwater from wells next to the AAC plotted along the same evaporative trend line as the surface water in the Colorado River upstream from Imperial Dam, indicating that recent Colorado River water was the primary source of recharge to groundwater to the wells. The isotopic composition of groundwater in most of the wells next to the AAC were heavier (less depleted) than the surface water in the Colorado river upstream from Imperial Dam, indicating evaporation between the time that surface water in the river flowed from Imperial Dam and recharged the aquifer next to the AAC. The ${ }^{3} \mathrm{H}$ activities of groundwater from the wells next to the AAC ranged from 5 to $15.5 \mathrm{TU}$ (see appendix table 1-2). These data indicated that the groundwater mostly had been recharged since 1953 . The ${ }^{14} \mathrm{C}$ activities of groundwater sampled from two of these wells (PK-1, IID Drop 4) were 86 and 89 pmC (fig. 20). Although uncorrected ages for these ${ }^{14} \mathrm{C}$ activities corresponded to groundwater ages between 900 and 1,200 years before present, the higher ${ }^{14} \mathrm{C}$ activities, along with the presence of ${ }^{3} \mathrm{H}$, indicated relatively recent recharge mixing with older water.

The isotopic composition of groundwater from wells in the Algodones Dunes ranged from -100 to -94 per mil $\delta^{2} \mathrm{H}$ and -12.2 to -12.3 per mil $\delta^{18} \mathrm{O}$ (figs. 18,19 ; see appendix table 1-2). These samples were isotopically similar to groundwater from wells next to the AAC. Unlike the seepage water from the AAC, however, the groundwater in well PK-7 had no measurable tritium, indicating recharge prior to 1953 (fig. 20). In addition, the ${ }^{14} \mathrm{C}$ activity of groundwater from this well was $44 \mathrm{pmC}$, corresponding to an uncorrected ${ }^{14} \mathrm{C}$ age for groundwater recharge of 6,700 years. It is likely that groundwater in this well was mostly a mixture, containing recharge from older, isotopically lighter, historic underflow from the east and more recent, isotopically heavier water, recharged prior to 1953. Groundwater from well NDL1, in the Algodones Dunes $1.5 \mathrm{mi}$ south of the AAC, had a ${ }^{3} \mathrm{H}$ activity of $22.9 \mathrm{TU}$ and a ${ }^{14} \mathrm{C}$ activity of $82 \mathrm{pmC}$, indicating a mixture of groundwater of differing ages in the well. The high ${ }^{3} \mathrm{H}$ activity coupled with intermediate isotopic values, however, indicated that groundwater in this well was most likely derived primarily from seepage recharge from the AAC.

Groundwater from wells on the East Mesa (CH-4, 9E1) had different isotopic compositions and ${ }^{3} \mathrm{H}$ and ${ }^{14} \mathrm{C}$ activities from one another, consistent with variable mixing of seepage of Colorado River water from the AAC and Coachella Canal with historic groundwater (figs. 18, 19). Groundwater from well $\mathrm{CH}-4$, about 2 miles north of the AAC and 1 mile west of the Coachella Canal, had an isotopic composition of -104 per mil $\delta^{2} \mathrm{H}$ and -13.3 per mil $\delta^{18} \mathrm{O}$, which was similar to the isotopic composition of groundwater on the western Pilot Knob Mesa (figs. 18, 19). The groundwater in this well was likely a mix of historic underflow from the east with more recent seepage recharge from the AAC. The ${ }^{3} \mathrm{H}$ activity in the sample from $\mathrm{CH}-4$ was $15.5 \mathrm{TU}$, indicating a substantial fraction of water recharged after 1953 (fig. 20). The ${ }^{14} \mathrm{C}$ activity of groundwater from this well was $56 \mathrm{pmC}$, corresponding to an uncorrected ${ }^{14} \mathrm{C}$ age of 4,800 years, which was consistent with the well yielding a mixture of groundwater of different ages. Groundwater from well 9E1, about $5 \mathrm{mi}$ north of the AAC and $1.5 \mathrm{mi}$ west of the Coachella Canal, had an isotopic composition of -85 per mil $\delta^{2} \mathrm{H}$ and -11.2 per mil $\delta^{18} \mathrm{O}$, which was different from any other groundwater sampled. The isotopic data plotted near the meteoric water line, indicating that groundwater in this well could have been recharged from local precipitation, in part. Tritium in groundwater from this well was less than $1 \mathrm{TU}$, and the ${ }^{14} \mathrm{C}$ of groundwater from this well was $21 \mathrm{pmC}$, corresponding to an uncorrected ${ }^{14} \mathrm{C}$ age of 12,900 years (fig. 20). The groundwater in this well was most likely a mixture, containing recharge from historic underflow from the east and recharge from historic precipitation or lacustrine events. There is no evidence to indicate recharge of seepage from the AAC or Coachella Canal to well 9E1.

\section{Groundwater Quality}

Groundwater quality from wells sampled during 2007-11 (figs. $10 C, 11 C$; see appendix table 1-2) was somewhat similar to the groundwater quality from wells sampled during 1961-65 by Loeltz and others (1975; figs. 10B, 11B). Groundwater collected from wells along the Cargo Muchacho Mountains Piedmont (Gold Rock Ranch, Cactus Well, Site 3) was a sodium-chloride type water (fig. 11C), indicative of the historic groundwater previously identified for this area. The TDS concentrations of the water in these wells ranged from $800 \mathrm{mg} / \mathrm{L}$ at Site 3 to 2,600 mg/L at the Cactus well (fig. 10C).

Groundwater collected from wells next to the AAC predominantly was a mixed cation-sulfate type water, but ranged to a sodium-chloride type (fig. 11C). The variation in water-quality characteristics in groundwater along the AAC is most likely indicative of varying mixtures of mixed cationsulfate type recharge from the AAC with sodium-chloride type water representing historic groundwater-quality conditions. The TDS of the groundwater in wells next to the AAC was mostly less than $879 \mathrm{mg} / \mathrm{L}$, similar to the concentrations in surface water from the Colorado River upstream from Imperial Dam (fig. 21) during 2007-11, which is potentially indicative of seepage recharge from the AAC. Groundwater collected from two wells next to the AAC near Pilot Knob, PK-1 and P-13.4, however, had higher TDS concentrations of 1,700 and $1,200 \mathrm{mg} / \mathrm{L}$, respectively, and was more sodium-rich than other wells along the AAC (figs. 10C, 11C), potentially indicative of less recharge from the AAC near Pilot Knob.

Groundwater collected from the two wells on the East Mesa also indicated a mixture of different sources of groundwater recharge. Groundwater collected from well $\mathrm{CH}-4$ was a sodium-sulfate type water that had a TDS concentration of $700 \mathrm{mg} / \mathrm{L}$, indicative of seepage from the AAC and possibly also the Coachella Canal (figs. 10C, 11C). Groundwater from well 9E1 was a sodium-chloride type water that had a TDS of $1,000 \mathrm{mg} / \mathrm{L}$, indicating less mixing with surface-water recharge than at well $\mathrm{CH}-4$. These conclusions are supported by the isotopic and age-dating data previously discussed. 


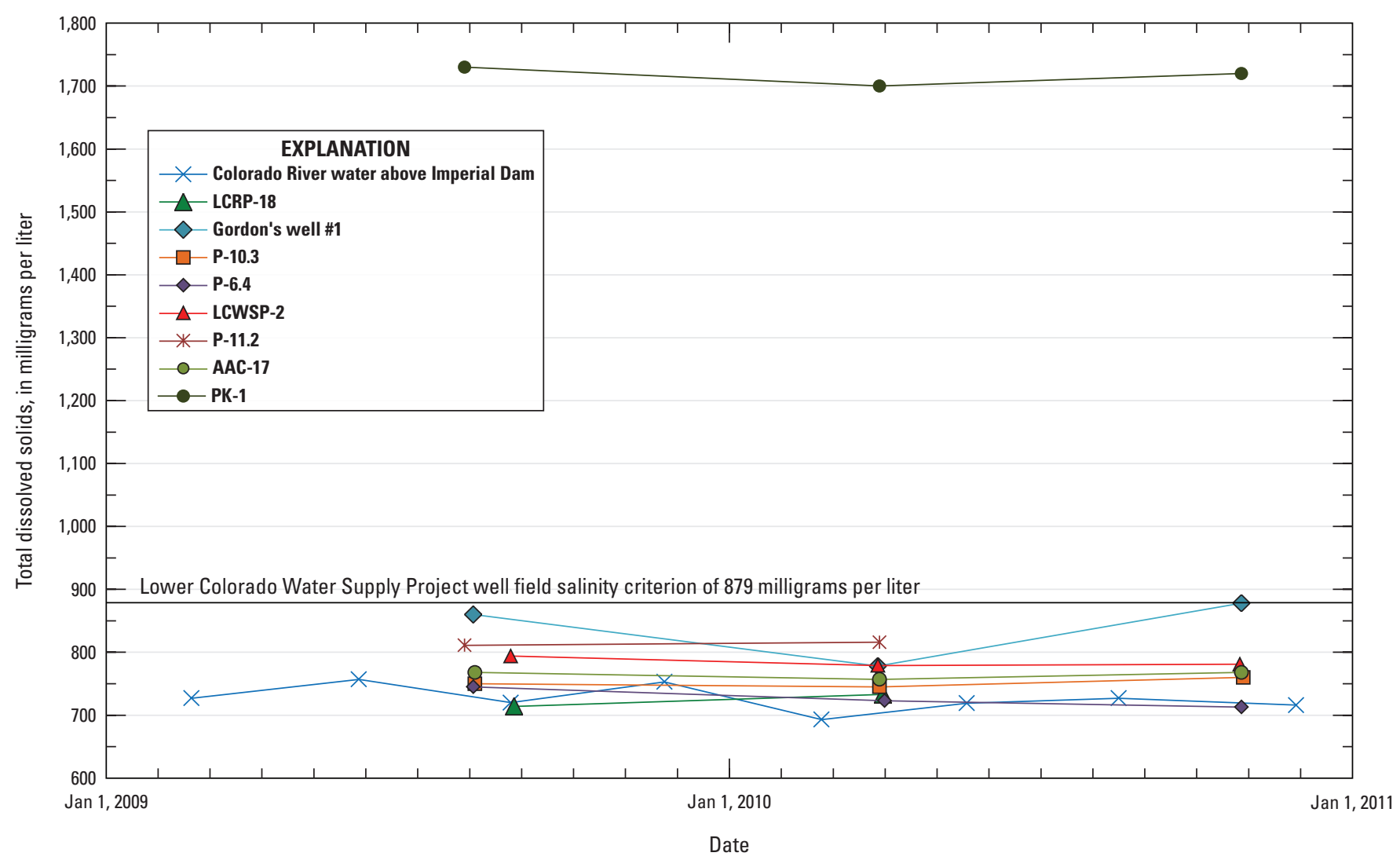

Figure 21. Total dissolved solids concentration by time in groundwater from selected wells and surface water in the Colorado River upstream from Imperial Dam, Imperial Valley, California, 2009-11.

Groundwater collected from wells on the Pilot Knob Mesa had a range of mixed cation-chloride type water to sodium-chloride type water (fig. 11C). Groundwater from two wells on the western part of Pilot Knob Mesa (Site 1, PK-0) was more sodium rich than groundwater from the other four wells. The TDS concentrations of water in the wells on the Pilot Knob Mesa ranged from 500 to $2,500 \mathrm{mg} / \mathrm{L}$, with the higher TDS concentrations on the northern and western portion of the Pilot Knob Mesa and the lower TDS concentrations on the eastern portion of Pilot Knob Mesa (fig. 10C). The differences in the groundwater quality in this area were most likely indicative of the complex nature of the aquifer system, as recharge from the AAC mixed with sodiumchloride type water representing historic groundwater-quality conditions.

Groundwater collected from two wells in the Algodones Dunes (PK-7, NDL1) similarly indicated different sources of groundwater recharge. Groundwater collected from well PK-7 in the Algodones Dunes north of the AAC was a sodiumchloride type water that had a TDS of $1,050 \mathrm{mg} / \mathrm{L}$, which was indicative of historic groundwater (figs. 10C, 11C). Groundwater collected from well NDL1 in the Algodones Dunes south of the AAC was sodium-sulfate type water that had a TDS of $700 \mathrm{mg} / \mathrm{L}$, which was indicative of seepage from the AAC.

\section{Salinity by Groundwater Depth}

Estimates of salinity by depth were modeled along a south-north transect by using TEM data collected during this study from several locations between the AAC at well AAC-12 Deep and Cactus Well (fig. 7). For the purpose of discussion, the TEM transect from the AAC to the Cactus well was divided into three sections from south to north for evaluation (fig. 22). The southern transects were in the Algodones Dunes (figs. 22A-B); the northern-most transect was to the east of the dunes on alluvial deposits of the Cargo Muchacho Mountains Piedmont, where the land surface consists of desert hardpan and desert-varnished cobbles (fig. 22C). The TEM model interpretations of resistivity where soundings were not done are not given because interpolations over a large area between soundings are not likely to be accurate. Similarly, uncertainties in the model interpretation of resistivity increase with depth, and model estimates of resistivity below about $1,000 \mathrm{ft}$ below land surface are not presented. 

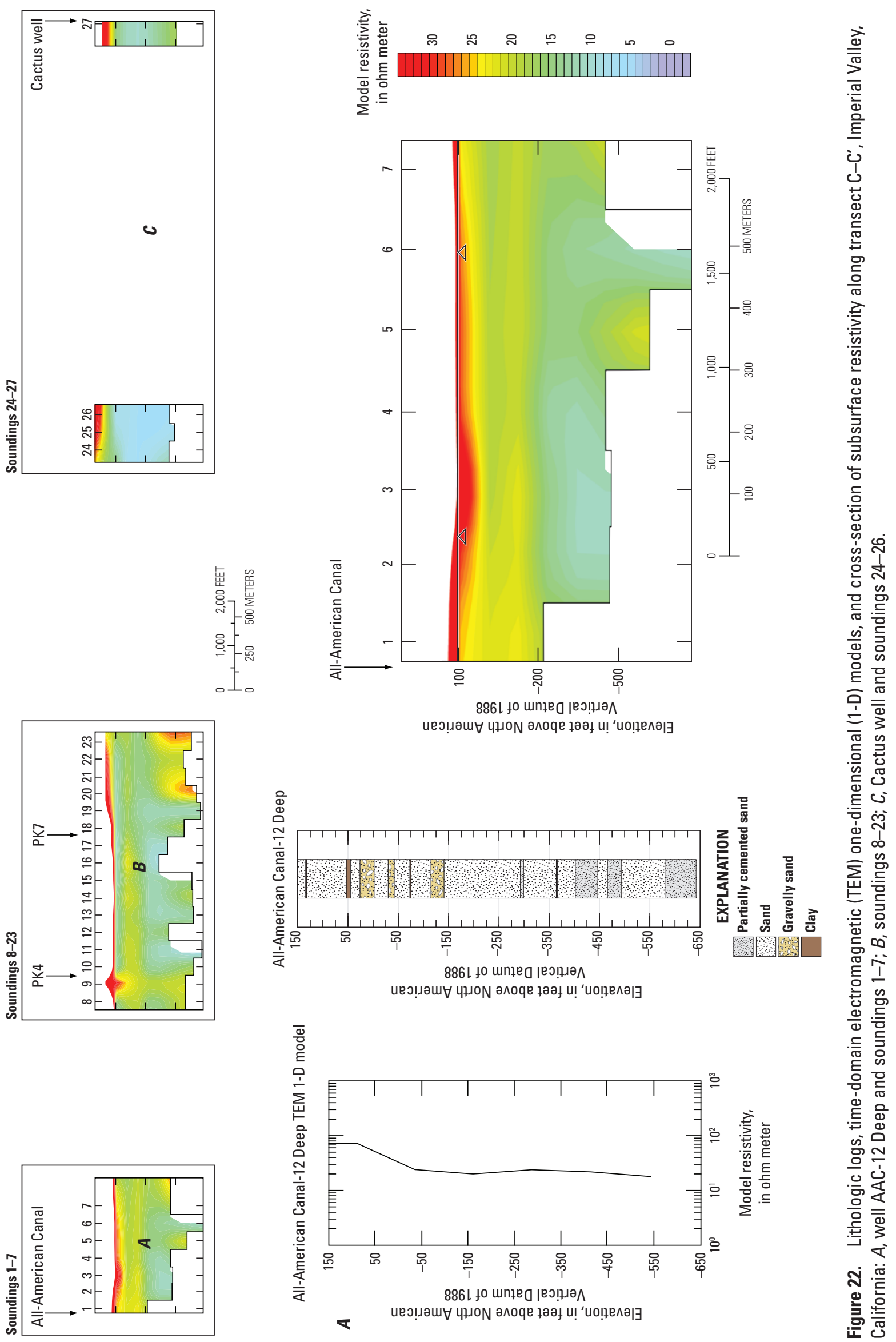

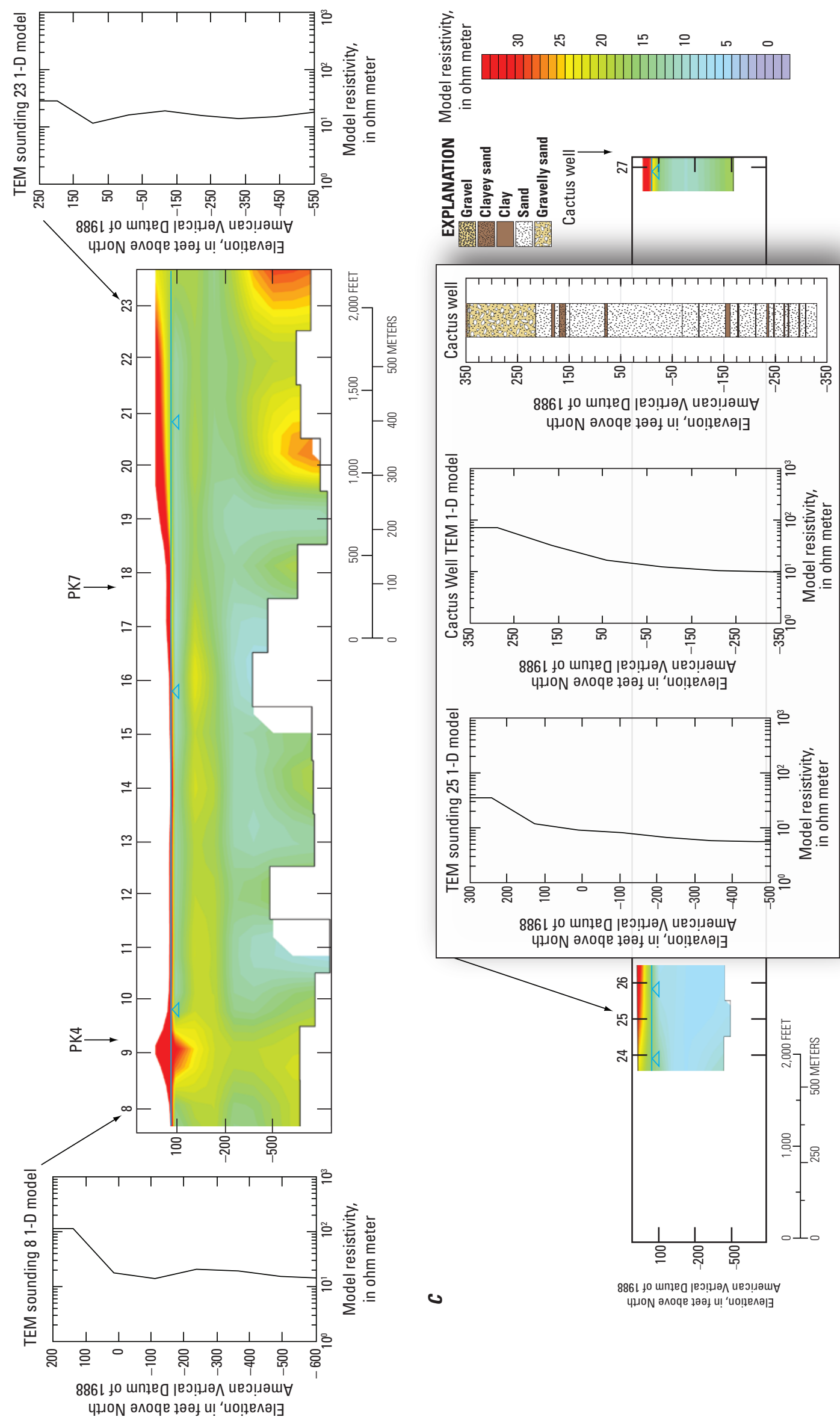

w

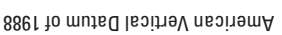

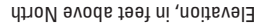

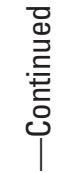


Near the area closest to the AAC (fig. 22A), TEM models indicated a shallow resistive zone and a conductive zone at depth. The top of the TEM cross-section is the land surface, and the upper 100-150 ft of material is a resistive zone (greater than $30 \mathrm{ohm}-\mathrm{m}$ ) that represents the near-surface aeolian sand deposits observed as sand dunes at the surface. The water table in well AAC-12, near the AAC, was about $138 \mathrm{ft}$ (39 ft bls; see appendix table 1-1); in the AAC-12 Deep TEM 1-D model, this groundwater elevation appeared to correspond to a change in slope where resistivity decreased. However, in the TEM cross section, the apparent decrease in resistivity from greater than $30 \mathrm{ohm}-\mathrm{m}$ to between 20 and $30 \mathrm{ohm}-\mathrm{m}$ was at an elevation of about $100 \mathrm{ft}$ (about $77 \mathrm{ft}$ below land surface at AAC-12 Deep). One explanation for why the modeled groundwater elevation in the TEM cross section differed from the measured groundwater elevation at AAC-12 is that the TEM loop size of $330 \mathrm{ft}(100 \mathrm{~m})$ and spacing between soundings was too large to constrain a shallow target of $39 \mathrm{ft}$ bls. Resistivity values between 20 and $30 \mathrm{ohm}$-m for TEM soundings 1 through 7 between an elevation of 100 and $-200 \mathrm{ft}$ probably represent sediments saturated with lower salinity (more resistive, less conductive) water seeping from the AAC; the borehole lithology did not vary in this depth. Below an elevation of $-200 \mathrm{ft}$ between TEM soundings 2 and 7, there was a decrease in resistivity, and values ranged between 10 and $20 \mathrm{ohm}-\mathrm{m}$, which could represent sediments saturated with historic, more saline, groundwater.

Moving to the north from the AAC (fig. 22B), TEM models indicated a transitional area where lower salinity water leaking from the AAC is most likely mixing with higher salinity (less resistive, more conductive), historic groundwater. Between TEM soundings 8 and 23, there was a zone where saturated sediments having resistivity values from 20 to $30 \mathrm{ohm}-\mathrm{m}$ appeared to be interspersed with a zone of sediments having resistivity values from 5 to $10 \mathrm{ohm}-\mathrm{m}$. The upper couple hundred feet of section B had a more resistive (greater than $30 \mathrm{ohm}-\mathrm{m}$ ) zone between soundings 8 and 10 that represents unsaturated sand dunes; this zone thinned northward and thickened between soundings 18 and 23 at the edge of the sand dunes. At sounding 9, the more resistive zone was underlain by a zone of sediments having $20-30 \mathrm{ohm}-\mathrm{m}$ resistivity values that extended to the depth of investigation. North and south of sounding 9 , the zone of sediments having 20-30 ohm-m values were found from about $50 \mathrm{ft}$ to $-200 \mathrm{ft}$. A zone of 5-20 ohm-m resistivity values were found below an elevation of $-200 \mathrm{ft}$ and could represent sediments saturated with historic, more saline, groundwater. There were also some more resistive (greater than $30 \mathrm{ohm}-\mathrm{m}$ ) zones at TEM soundings 20 and 23 below an elevation of $-500 \mathrm{ft}$. The high resistivity areas at depth could be major changes in lithology or errors in the TEM soundings that could not be constrained during modeling.

As the TEM transect approaches the Cactus Well (fig. 22C), TEM models indicated a less resistive (more conductive) subsurface where resistivity values typically ranged from about 5 to $10 \mathrm{ohm}-\mathrm{m}$ below an elevation of $100 \mathrm{ft}$ beneath soundings 24-26 and ranged from 5 to $25 \mathrm{ohm}-\mathrm{m}$ below an elevation of $100 \mathrm{ft}$ beneath sounding 27 at the Cactus well. The sediments in this area are alluvial deposits, as opposed to sand dunes. The $5-10 \mathrm{ohm}-\mathrm{m}$ values in this area could represent sediments saturated with higher-salinity historic groundwater. The groundwater elevation at the Cactus well was $121 \mathrm{ft}$ (255 ft bls; see appendix table 1-1). There was a resistivity change from greater than $30 \mathrm{ohm}-\mathrm{m}$ to 20-25 ohm-m in the 1-D TEM profile at an elevation of about $150 \mathrm{ft}$, which appeared to represent the water table.

\section{Lower Colorado Water Supply Project}

\section{Groundwater Elevations and Wellbore Flow}

Static groundwater elevations in LCWSP-2, measured during non-pumping conditions, remained relatively constant between 1993 and 2000 (fig. 23). After lining the AAC in 2007-10, static groundwater elevations in LCWSP-2 were 22-37 ft lower from December 2009 to May 2011 than in 1999. Groundwater elevations during pumping declined about $9 \mathrm{ft}$ between November 2009 and February 2011. Groundwater-elevation data during August 2009 through May 2011 indicated a groundwater-level difference of about $65 \mathrm{ft}$ between static and pumping conditions; both declined during this period (fig. 23).

Over the screened interval from 200 to $400 \mathrm{ft}$ bls, well LCWSP-2 is open primarily to sands, with a few minor intervals of gravel, clay, or cemented sand (fig. 24). The wellbore-velocity profile for LCWSP-2 indicated that about one-half of the water pumped from the well entered the screened interval between 200 and $270 \mathrm{ft}$ bls (fig. 24). This screened interval contains a number of gravel intervals. Most of the remaining water pumped by the well entered the screened interval between 270 and $370 \mathrm{ft}$ bls. Only about 5 percent of the water pumped by the well entered the screened interval between 370 and $400 \mathrm{ft}$ bls. 


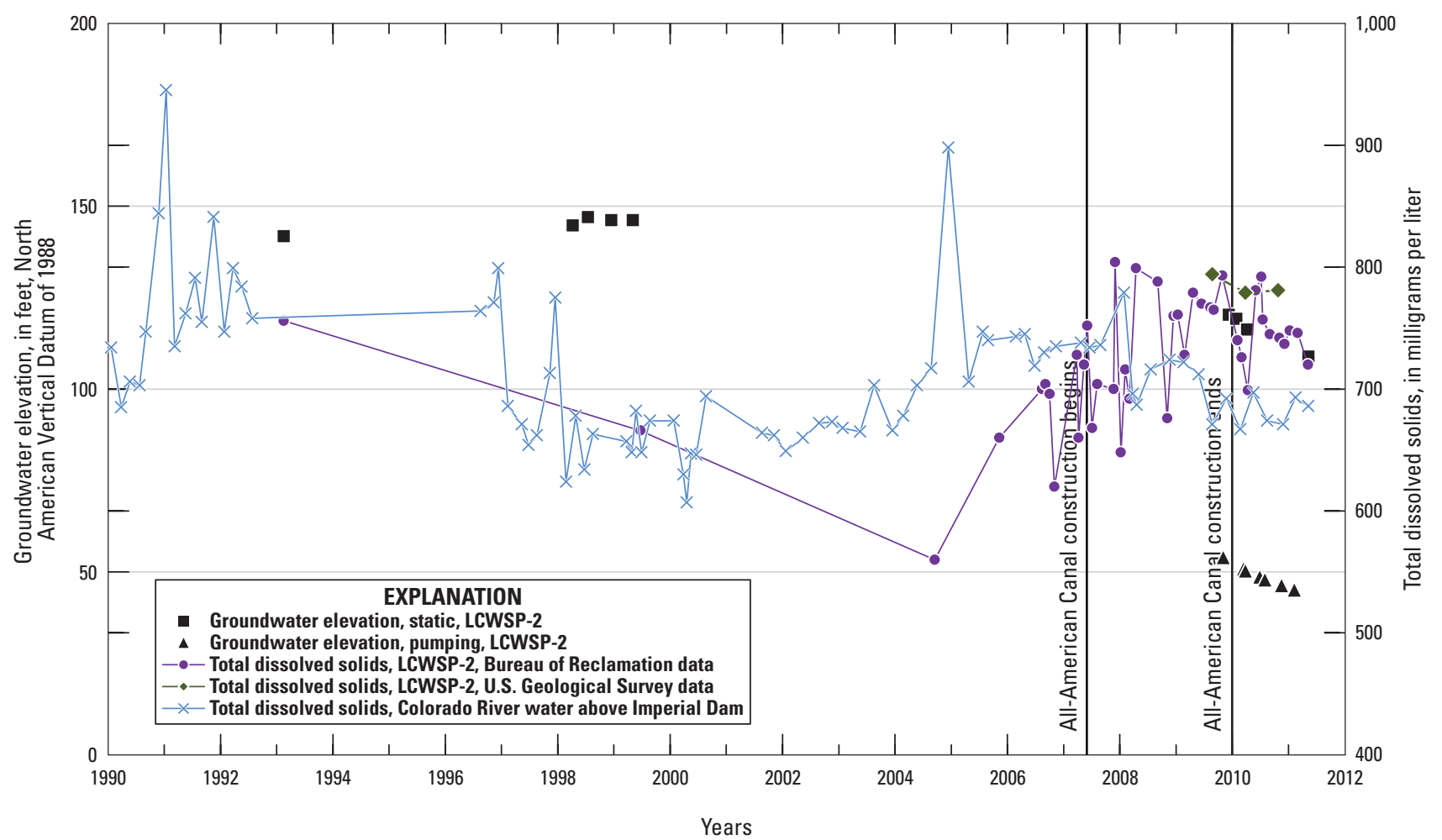

Figure 23. Total-dissolved-solids concentrations and groundwater elevation, 1990-2011, in well LCWSP-2 and total-dissolved-solids concentrations in surface water in the Colorado River upstream from Imperial Dam, Imperial Valley, California.

\section{Groundwater Quality}

Groundwater-quality samples, collected in 1941 from two wells within 4 miles of the LCWSP well-field area soon after the completion of the AAC construction, were notably different from groundwater-quality samples from wells in the same area in 2009-11, following over 60 years of recharge from the AAC (fig. 25). In 1941, groundwater samples from wells in the future well-field area were predominantly sodiumchloride/sulfate type water having TDS concentrations of 520 and $570 \mathrm{mg} / \mathrm{L}$, indicative of historic groundwater in this area. In 2009-11, groundwater samples from wells in the well-field area were mixed cation-sulfate type water having a TDS concentration range of $713-816 \mathrm{mg} / \mathrm{L}$. The change in groundwater elevation and quality in the area of the LCWSP well field reflected infiltration of surface water from the AAC and recharge of the shallow-aquifer system along the canal.

The TDS concentrations in LCWSP-2 from 1993 to 2006, prior to canal lining, ranged from 560 to $750 \mathrm{mg} / \mathrm{L}$ and were generally similar to or less than TDS concentrations in the Colorado River upstream from Imperial Dam (fig. 23). The TDS concentrations in LCWSP-2 from 2007 to 2011, during and after canal lining, ranged from 650 to $800 \mathrm{mg} / \mathrm{L}$ and were generally similar to or greater than TDS concentrations in the Colorado River upstream from Imperial Dam. Beginning in about 2009, midway through the lining of the canal, TDS concentrations in LCWSP-2 became consistently greater than
TDS concentrations in the Colorado River. The TDS could have stabilized in the groundwater at LCWSP-2 because the aquifer system was no longer receiving recharge of Colorado River water from the AAC, and more groundwater was being pumped from the surrounding aquifer.

Results of the depth-dependent samples collected from well LCWSP-2 indicated that the groundwater pumped from the deeper part of the screened interval contained a greater component of historic groundwater than the groundwater pumped from the shallower part of the screened interval. The two shallower samples contained less sodium and more calcium than did the two deeper samples (fig. 26; see appendix table 1-3). The TDS of the two shallower samples was higher (781 and $784 \mathrm{mg} / \mathrm{L}$ ) than the TDS of the two deeper samples ( 734 and $737 \mathrm{mg} / \mathrm{L}$ ). The stable isotope data for groundwater from the four depths were all similar to isotopic data for groundwater from wells next to the AAC; however, the isotopic data in the two shallower samples from $240 \mathrm{ft}$ and $280 \mathrm{ft}$ were heavier (less depleted) and plotted further along the evaporative trend line than isotopic data for the two deeper samples from $350 \mathrm{ft}$ and $385 \mathrm{ft}$ (fig. 27; see appendix table 1-3). The higher sodium content, lower TDS concentrations, and more depleted isotopes of the two deeper samples indicated that, at the deeper depths, the recharge from the AAC was mixing with a larger component of higher-sodium, lower TDS, isotopically depleted, historic groundwater than at the shallower depths. 


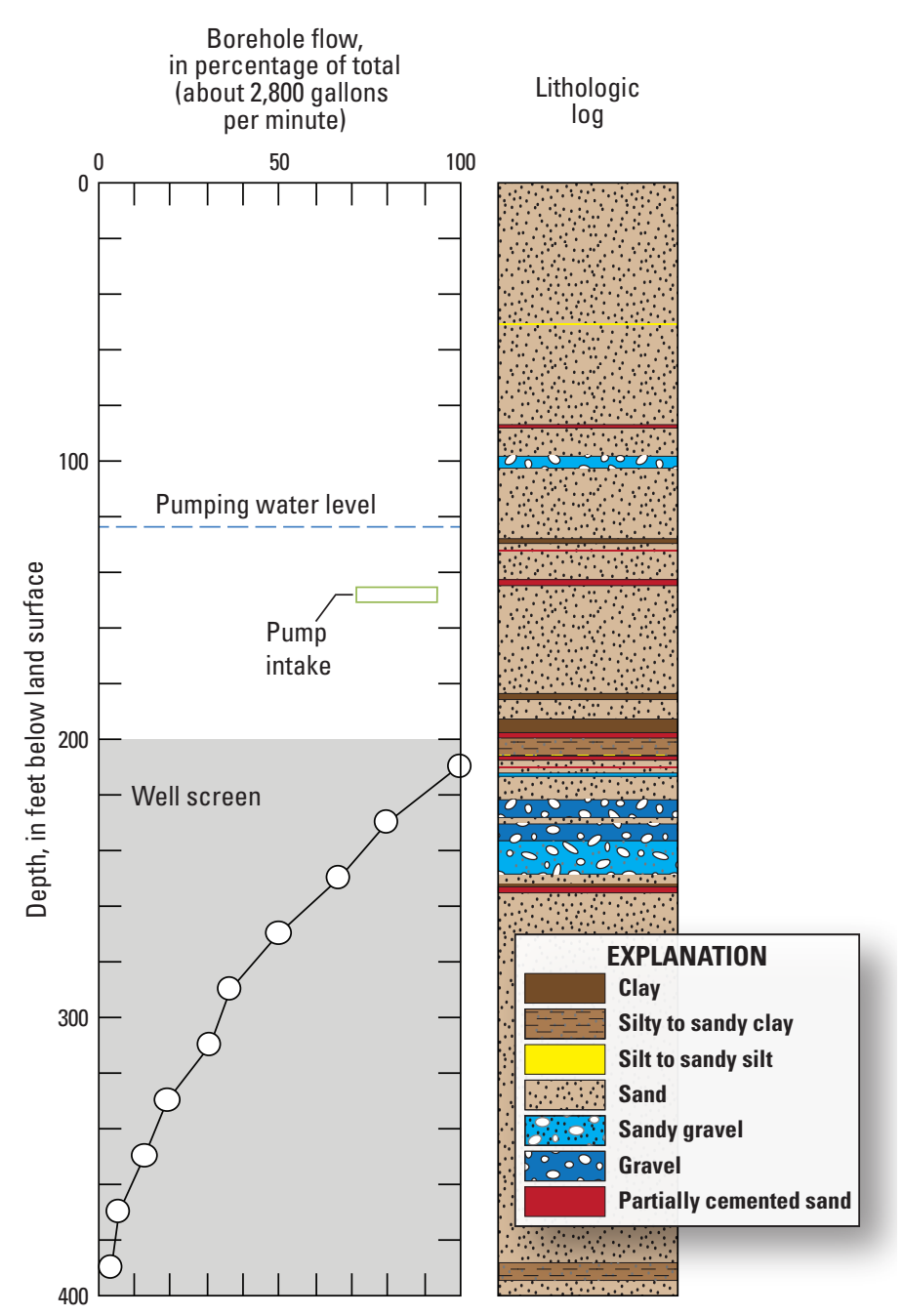

Figure 24. Wellbore-velocity profile and lithology in well LCWSP-2 at Lower Colorado Water Supply Project, Imperial Valley, California, August 2009.
The age tracer $\left({ }^{3} \mathrm{H}\right)$ data indicated that all depths sampled in the LCWSP-2 well had received recent recharge from seepage of Colorado River water from the AAC. Groundwater sampled from the four depths contained ${ }^{3} \mathrm{H}$ activities from 6.6 to $7.9 \mathrm{TU}$ (see appendix table $1-3$ ). The ${ }^{14} \mathrm{C}$ activity from the sample collected at $385 \mathrm{ft}$ bls was $94 \mathrm{pmC}$ (uncorrected ${ }^{14} \mathrm{C}$ age less than 1,000 years; see appendix table $1-3$ ) and indicated that most groundwater at this depth had been recharged relatively recently. 


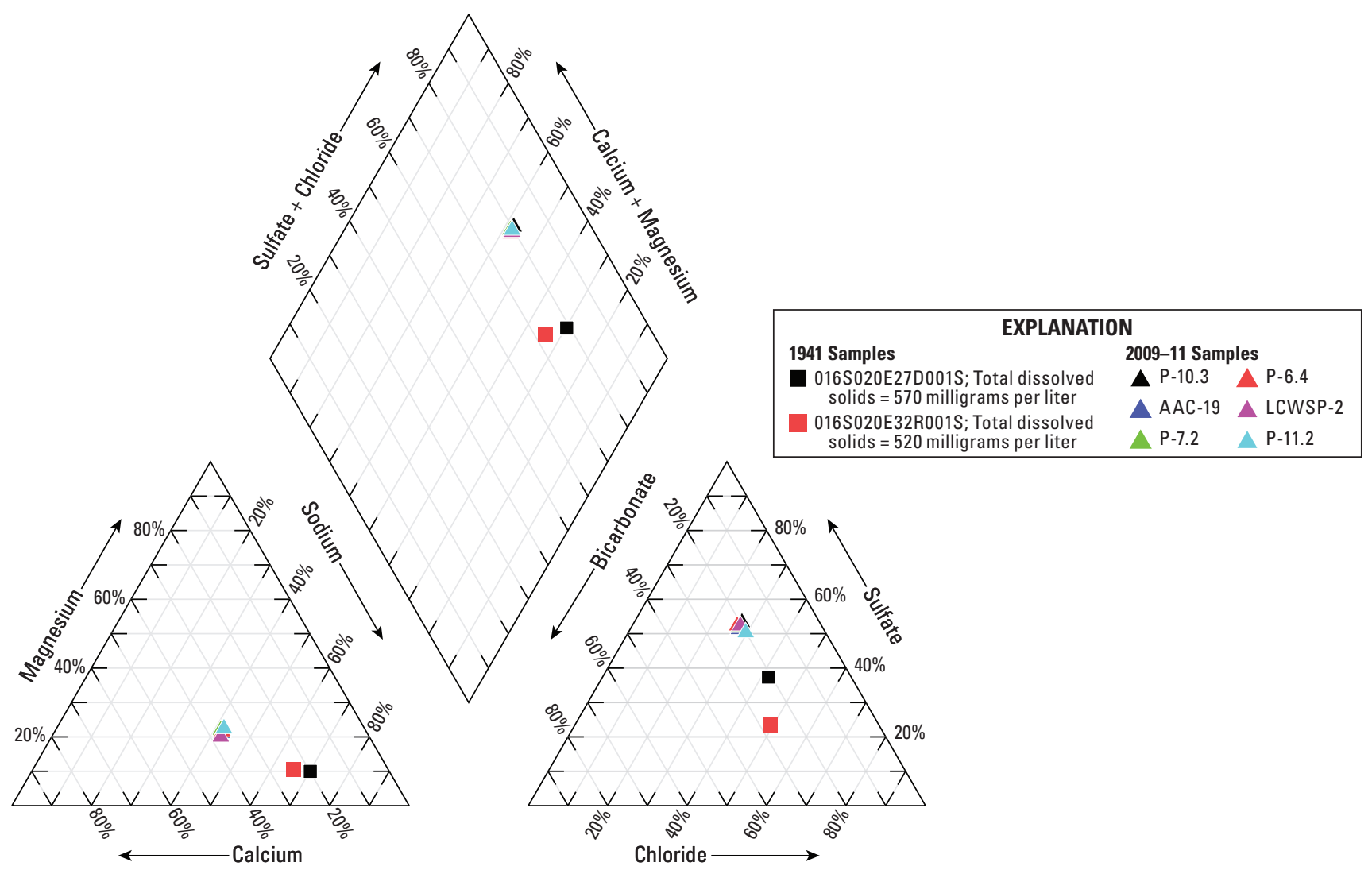

Figure 25. Groundwater quality in the vicinity of the Lower Colorado Water Supply Project, Imperial Valley, California, 1941 and 2009-11. 


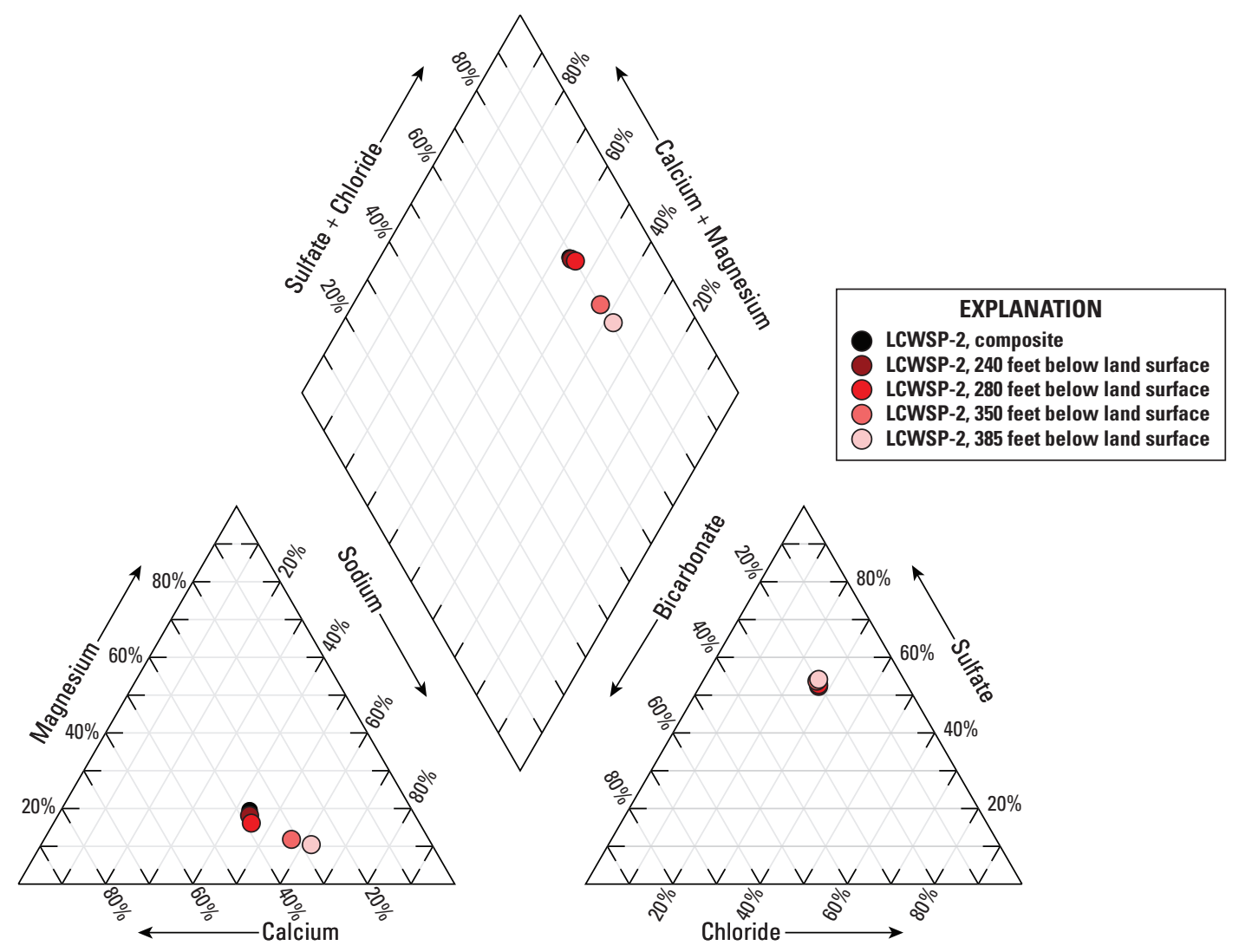

Figure 26. Groundwater quality from various depths below land surface (BLS) in well LCWSP-2, Imperial Valley, California, August 2009. \%, percent.

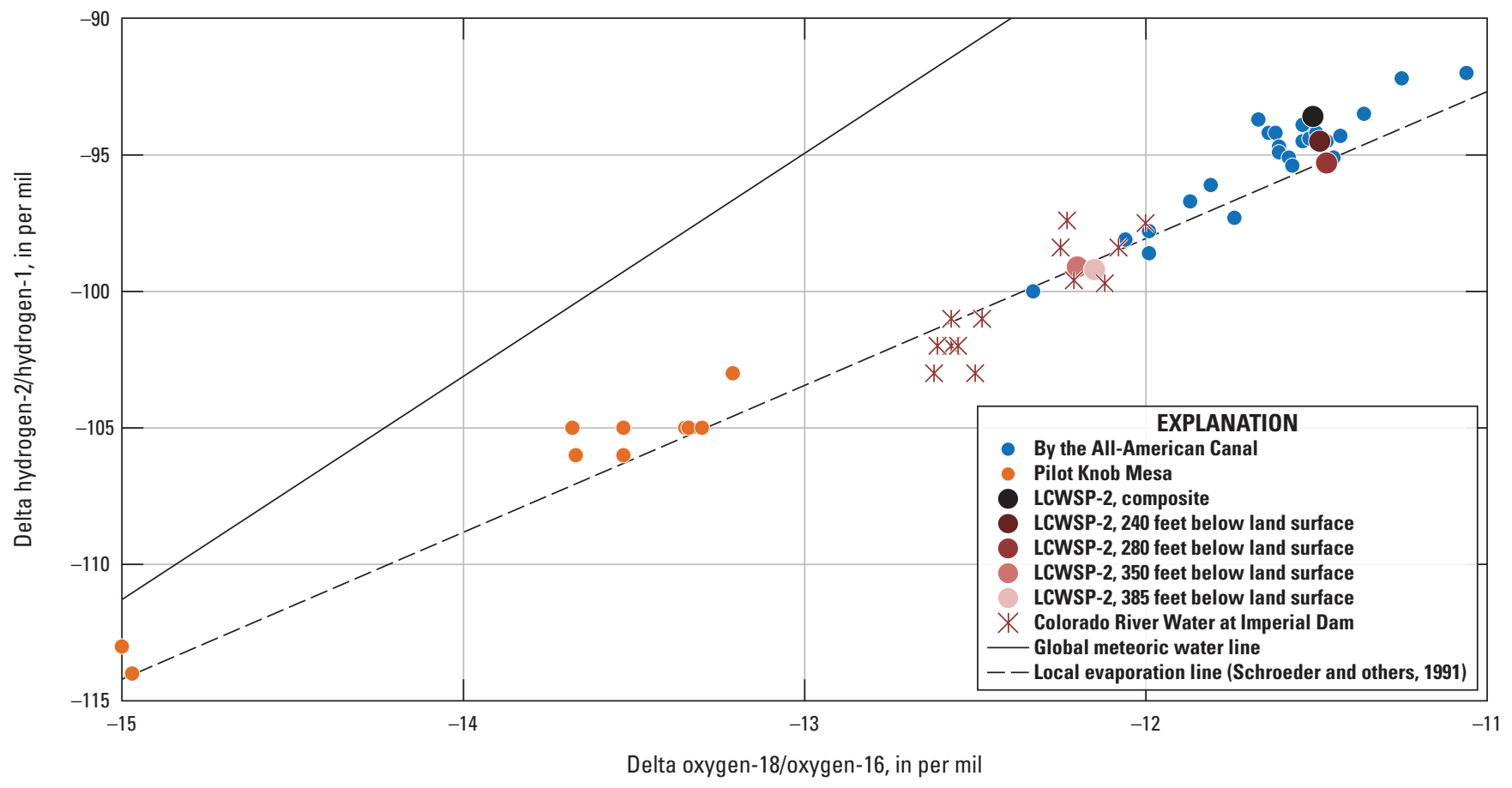

Figure 27. Delta hydrogen-2/hydrogen-1 and delta oxygen-18/oxygen-16 in groundwater from various depths below land surface (BLS) in well LCWSP-2, Imperial Valley, California, August 2009. 


\section{Study Limitations and Recommendations}

The results of this investigation have several limitations. Groundwater-elevation and groundwater-quality data were not obtained for the aquifer to the south of the AAC in Mexico to confirm southward movement of canal seepage. Limited water-quality data were available for surface water in the AAC near the LCWSP well field; instead, water-quality data for the Colorado River upstream from Imperial Dam, upstream from the study area, were substituted for water in the AAC. Additionally, because there were few existing deep wells, depth-dependent, vertically stratified groundwater-quality data were sparse in the study area. There is a need for more information about aquifer properties and water quality at greater depths than current wells extend near the LCWSP well field.

The continuation of groundwater-elevation, microgravity, and water-quality monitoring is needed to analyze the effect of lining the AAC and other management actions on TDS concentrations in groundwater pumped by the LCWSP. Changes in the aquifer conditions can take several decades to reflect the new management activities. Groundwaterelevation monitoring in the study area is needed to accurately record changes in the groundwater table after the mitigation of seepage recharge from the AAC. Microgravity monitoring also is needed to supplement the well network and refine estimates of storage properties and change. Groundwaterquality monitoring, especially of TDS, is needed to identify changes in water quality in the area of the LCWSP well field. Additional TEM surveys would help to define the groundwater salinity better by depth near and at a distance from the AAC. To estimate future groundwater elevations and TDS concentrations near the LCWSP, a three-dimensional numerical groundwater model of the region is needed to understand the effects of lining the AAC better and to identify optimal pumping rates and locations to meet water-quantity and quality needs as well as possible.

\section{Summary}

The All-American Canal (AAC), which supplies Colorado River water to agricultural users in Imperial Valley, recharged the local aquifer system through seepage losses from 1940 until lining of the canal was completed in 2010. The Lower Colorado Water Supply Project (LCWSP) is next to the AAC and has withdrawn groundwater to supply California users since the mid-1990s. In 2009, the U.S. Geological Survey began a study to establish a monitoring network and to provide an initial characterization of the aquifer system in the vicinity of the LCWSP. A monitoring network was established to characterize the effect of the loss of recharge from the AAC system on the quantity and quality of groundwater in the aquifer system in the vicinity of the LCWSP. In addition, a preliminary hydrogeologic characterization of the aquifer system in the vicinity of the LCWSP was completed.

Historic groundwater-elevation, groundwater-quality, well-completion, borehole-log, surface-water discharge, and surface-water quality data were compiled, quality assured, and archived. A groundwater-elevation network of 39 wells was established, and groundwater elevations were measured every 1 to 3 months; additionally, hourly groundwater elevations were recorded in 11 of the wells. A groundwater-quality network of 24 wells was established, and 1 to 3 groundwaterquality and isotope samples were collected from each well. At one of the LCWSP wells, depth-specific water-quality and isotope samples were collected, wellbore velocity was determined, and an aquifer-recovery test was completed. Repeat microgravity measurements were made at four crosssections across the AAC in the vicinity of the LCWSP to monitor groundwater-storage change.

Prior to the construction of the AAC in 1940, the aquifer system was in steady state. Groundwater movement was from east to west, and groundwater was recharged primarily by underflow from the Colorado River Valley. Groundwater in the southern part of the study area was primarily sodium-chloride/ sulfate type water having relatively low total dissolved solids (TDS) concentrations (500-820 mg/L).

After construction of the AAC, groundwater elevations and water quality were noticeably altered in the study area because seepage from the AAC and other canals recharged the aquifer system. By 2005, prior to lining the AAC, groundwater elevations had increased by as much as 50-70 feet along the AAC. The dominant source of recharge to the aquifer system was seepage from the AAC; groundwater movement was still generally from east to west; superimposed on the east to west gradient, however, was groundwater moving to the north, away from the AAC and, most likely, to the south. Groundwater quality in the southern part of the study area, next to the AAC, ranged from sodium-chloride type water to mixed-cation-sulfate type water.

After lining the AAC in 2007-10, groundwater elevations began to decline because seepage from the canal was removed as a recharge source, and groundwater flow directions shifted back to pre-canal conditions. Groundwater-elevation declines were greatest along the $\mathrm{AAC}$, where elevations decreased 20-40 feet between 2005 and 2011. Groundwater elevations in the vicinity of pumping from the LCWSP had the greatest decreases, as much as 40-45 feet between 2005 and 2011. By 2011, groundwater movement generally had returned to a predominantly east to west flow direction.

Water-quality and isotope data indicated that the water that had been recharging the aquifer system from seepage of Colorado River water from the AAC is geochemically and isotopically distinct from historically recharged groundwater. In 2009-11, groundwater near the AAC ranged from sodiumchloride type water to mixed-cation-sulfate type water. Additionally, in 2009-11, groundwater near the AAC had 
a stable-isotopic signature indicative of Colorado River water that had been affected by evaporation; radioactive isotopes indicated that the groundwater in this area included a substantial fraction of water had been recharged recently, within the past 60 years. In contrast, historic groundwater had higher sodium and chloride concentrations, and lower calcium and sulfate concentrations, compared to recharge from the $\mathrm{AAC}$, as well as a distinctly heavier stable-isotopic signature and no evidence of recharge in the past 60 years.

Both the recent recharge of Colorado River water from the AAC and the historically recharged groundwater in the area near the AAC had low TDS concentrations relative to groundwater in other parts of the study area. Groundwater in the East Mesa, Algodones Dunes, Pilot Knob Mesa, and Cargo Muchacho Mountains Piedmont generally had totaldissolved-solids concentrations greater than 1,000 milligrams per liter. The groundwater in these areas had higher sodium and chloride concentrations, and lower calcium and sulfate concentrations, than groundwater near the AAC. Timedomain electromagnetic data indicated that low-salinity groundwater was present up to an elevation of about -200 feet (377 feet below land surface) near the AAC; groundwater salinity at depth increased with distance north from the AAC. Groundwater several miles or more from the canal did not contain tritium and had a residence time on the order of thousands to tens of thousands of years. The groundwater in the piedmont of the Cargo Muchacho Mountains had a distinct, enriched stable-isotopic signature, whereas the stable-isotopic signature of groundwater in the East Mesa and the Algodones Dunes indicated a mixture of groundwaterrecharge sources.

Groundwater elevations at the LCWSP have been decreasing since the onset of lining the AAC in 2007. Between December 2009 and May 2011, the static groundwater elevation in one of the LCWSP wells decreased 23-37 feet, and the pumping groundwater elevation decreased 9 feet. Total-dissolved-solids concentrations remained relatively constant in well LCWSP-2 during the course of this study at 650-800 milligrams per liter. Depth-specific water-quality and isotope sampling at well LCWSP-2 indicated that at the deeper depths of the screened interval of this well (350-380 feet), the recent recharge from the AAC was mixing with a larger component of higher sodium, lower TDS, isotopically depleted, historic groundwater than at the shallower depths of the well.

\section{References Cited}

Axen, G.J., and Fletcher, J.M., 1998, Late MiocenePleistocene extensional faulting, northern Gulf of California, Mexico and Salton Trough, California: International Geology Review, v. 40, no. 3, p. 217-244, http://dx.doi.org/10.1080/00206819809465207.
Axiom-Blair Engineering, 2006, Groundwater investigations for dewatering-All American Canal lining project: Prepared for Bookman-Edmonston, 98 p.

Baldridge, W.S., Cole, G.L., Robinson, B.A., Jiracek, G.R., 2007, Application of time-domain airborne electromagnetic induction to hydrogeologic investigation on the Pajarito Plateau, New Mexico, USA: Geophysics, v. 72, no. 2, p. B31-B45, http://dx.doi.org/10.1190/1.2437701.

Biehler, Shawn, Kovach, R.L., and Allen, C.R., 1964, Geophysical framework of northern end of Gulf of California structural province in van Andel, T.H., and Shor, G.G., eds., Marine Geology of the Gulf of California: American Association of Petroleum Geologists Memoir, v. 3, p. 126-143, http://resolver.caltech.edu/ CaltechAUTHORS:20140923-093145767.

Blake, W.P., 1854, Ancient lake in the Colorado Desert: American Journal of Science v. 17, p. 435-438.

Blake, W.P., 1907, Lake Cahuilla-The ancient lake of the Colorado Desert: National Geographic Magazine, v. 18, p. 830 .

Boulder Canyon Project Act, 1928, United States Public Law 70-642, 70th Congress, H.R. 5773, December 21, 1928.

Brown, J.S., 1923, The Salton Sea region, California: A geographic, geologic, and hydrologic reconnaissance, with a guide to desert watering places: U.S. Geological Survey Water-Supply Paper 497, 292 p., 3 pls., http://pubs.er.usgs.gov/publication/wsp497.

Buckles, J.E., Kashiwase, Kazuyuki, and Krantz, Timothy, 2002, Reconstruction of prehistoric Lake Cahuilla in the Salton Sea Basin using GIS and GPS: Hydrobiologia, v. 473 , p. 55-57.

California Department of Water Resources, 2003, California's Groundwater: California Department of Water Resources Bulletin 118, Update 2003, 212 p., http://www.water.ca.gov/ groundwater/bulletin118/index.cfm.

California Geological Survey, 2010, 2010 Fault Activity Map of California: California Geological Survey Geologic Data Map No. 6, http:/www.quake.ca.gov/gmaps/FAM/ faultactivitymap.html.

Castro-Ruiz, J.L., and Sánchez-Munguia, Vicente, 2005, The lining of the All-American Canal: Effects on Mexico: Southwest Hydrology, September/October 2005, v. 4, no. 5, p. 26-27, http://www.swhydro.arizona.edu/archive/V4_N5/ feature7.pdf. 
Chávez, R.E., Lazaro-Mancilla, O., Campos-Enríquez, J.O., Flores-Márquez, E.L., 1999, Basement topography of the Mexicali Valley from spectral and ideal body analysis of gravity data: Journal of South American Earth Sciences, v. 12, no. 6, p. 579-587, http://dx.doi.org/10.1016/S0895-9811(99)00041-3.

Coplen, T.B., 1972, Origin of geothermal waters in the Imperial Valley of Southern California, in Rex, R.W., Beihler, S., Combs, J., Coplen, T.B., Furgerson, R.B., Garfunkel, Z., Getts, T.R., Maas, J.P., Reed, M., Cooperative investigation of geothermal resources in the Imperial Valley area and their potential value for desalting of water and other resources: Institute of Geophysics and Planetary Physics, University of California, Riverside, Report IGPP-UCR-72-33, p. E1-E33.

Coplen, T.B., and Kolesar, Peter, 1974, Investigations of the Dunes Geothermal Anomaly, Imperial Valley, California: Part 1. Geochemistry of Geothermal Fluids: Institute of Geophysics and Planetary Physics, University of California, Riverside, Report IGPP-UCR-74-18, 25 p., http://digitallib.oit.edu/cdm/ref/collection/geoheat/id/9316.

Day, Allen, 1906, The inundation of the Salton Basin by the Colorado River and how it was caused: Scientific American, v. 94 , no. 15 , p. $310-312$.

DeMets, Charles, 1995, A reappraisal of seafloor spreading lineations in the Gulf of California: Implications for the transfer of Baja California to the Pacific plate and estimates of Pacific-North America motion: Geophysical Research Letters, v. 22, no. 24, p. 3545-3548, http://geoscience.wisc.edu/ chuck/PDF/demets_gr195.pdf.

Derickson, Dana, Kocurek, Gary, Ewing, R.C., and Bristow, Charlie, 2008, Origin of a complex and spatially diverse dune-field pattern, Algodones, southeastern California: Geomorphology, v. 99, no. 1-4, p. 186-204, http://dx.doi.org/10.1016/j.geomorph.2007.10.016.

Dibblee, T.W. Jr., 1954, Geology of the Imperial Valley region, California, in chap. 2 of Jahns, R.H., ed., Geology of southern California: California Division of Mines Bulletin 170, p. 21-28.

Dickinson, J.E., Land, Michael, Faunt, C.C., Leake, S.A., Reichard, E.G., Fleming, J.B., and Pool, D.R., 2006, Hydrogeologic framework refinement, ground-water flow and storage, water-chemistry analyses, and water-budget components of the Yuma area, southwestern Arizona and southeastern California: U.S. Geological Survey Scientific Investigations Report 2006-5135, 88 p., http://pubs.usgs.gov/sir/2006/5135/.

Dorsey, R.J., 2006, Stratigraphy, tectonics, and basin evolution in the Anza-Borrego Desert region, in Jefferson, G.T., and Lindsay, L.E., eds., Fossil treasures of Anza-Borrego Desert: San Diego, California, Sunbelt Publications, p. 89-104.
Downs, Theodore, and Woodard G.D., 1962, Middle Pleistocene extension of the Gulf of California into the Imperial Valley, in The Geological Society of America, Abstracts for 1961: Geological Society of America Special Paper 68, p. 21, http://dx.doi.org/10.1130/SPE68-p1.

Durham, J.W., 1954, The marine Cenozoic of southern California, in Jahns, R.H., ed., Geology of southern California, chap. 3, Historical geology: Californian Division of Mines Bulletin 170, p 23-31.

Dutcher, L.C., Hardt, W.F., and Moyle, W.R., 1972, Preliminary appraisal of ground water in storage with reference to geothermal resources in the Imperial Valley area, California: U.S. Geological Survey Circular 649, 57 p., http://pubs.er.usgs.gov/publication/cir649.

Elders, W.A., Rex, R.W., Robinson, P.T., Biehler, Shawn, and Mediva, Tsvi, 1972, Crustal spreading in southern California: The Imperial Valley and the Gulf of California formed by the rifting apart of a continental plate: Science, v. 178 , no. 4056, p. 15-24, http://www.sciencemag.org/ content/178/4056/15.abstract.

Elders, W.A., Bird, D.K., Williams, A.E., and Schiffman, P., 1984, Hydrothermal flow regime and magmatic heat source of the Cerro Prieto geothermal system, Baja California, Mexico: Geothermics v. 13, no. 1-2, p. 27-47, http://dx.doi.org/10.1016/0375-6505(84)90005-1.

Elders, W.A., Williams, A.E., and Biehler, Shawn, 1997, What lies beneath the Cerro Prieto geothermal field?: Geothermal Resources Council Transactions, v. 21, p. 171-179, http://pubs.geothermal-library.org/lib/grc/1015558.pdf.

Feirstein, E.J., Zamora, Francisco, Vionnet, L.B., and Maddox, Thomas II, 2008, Simulation of groundwater conditions in the Colorado River Delta, Mexico: Tucson, Arizona, University of Arizona, Department of Hydrology and Water Resources, 173 p., http://www.geo.arizona.edu/ rencrd/documents/Delta\%20Study_Eden,\%20Francisco_ Maddock_2008.pdf.

Fenneman, N.M., 1931, Physiography of western United States: New York, N.Y., McGraw-Hill Book Company, $534 \mathrm{p}$.

Fenneman, N.M., and Johnson, D.V., 1946, Physical Divisions of the United States: U.S. Geological Survey special map, 1 sheet, scale 1:7,000,000.

Fitterman, D.V., and Labson, V.F., 2005, Electromagnetic induction methods for environmental problems, chap. 10, in Butler, D.K. ed., Near-surface geophysics, Investigations in geophysics: Society of Exploration Geophysicists, p. 301356, http://dx.doi.org/10.1190/1.9781560801719.ch10. 
Fuis, G.S., and Kohler, W.M., 1984, Crustal structure and tectonics of the Imperial Valley region, California: in Rigsby, C.A., ed., The Imperial Basin-Tectonics, sedimentation, and thermal aspects: Los Angeles California, The Pacific Section, Society of Economic Paleontologists and Mineralogists, p. 1-13.

Fuis, G.S., Mooney, W.D., Healy, J.H., McMechan, G.A., and Lutter, W.J., 1984, A seismic refraction survey of the Imperial Valley region, California: Journal of Geophysical Research, v. 89, no. B2, p. 1165-1189, http://dx.doi.org/10.1029/JB089iB02p01165.

Galloway, D.L., Jones, D.R., and Ingebritsen, S.E., eds., 1999, Land subsidence in the Unites States: U.S. Geological Survey Circular 1182, 177 p., http://pubs.usgs.gov/circ/circ1182/.

Ganster, P., ed., 2006, The U.S.-Mexican border environment-Lining the All-American Canal: Competition or cooperation for the water in the U.S.-Mexican border?: Southwest Consortium for Environmental Research and Policy Monograph Series, no. 13, San Diego State University Press, 242 p.

Geotechnics Inc., 2005, Geotechnical investigation, AllAmerican Canal lining project, Imperial County, California: Prepared for Parsons Water and Infrastructure Inc., no. 05-0816R, v. I, 750 p.

Gleason, J.D., Guida, Veronda, Smith, G.I., Friedman, Irving, and Martin, P.M., 1994, Deuterium content of water from wells and perennial springs, southeastern California: U.S. Geological Survey Hydrologic Atlas 727, 1 map, http://pubs.er.usgs.gov/publication/ha727.

Goldrath, D.A., Wright, M.T., and Belitz, Kenneth, 2010, Groundwater-quality data in the Colorado River study unit, 2007: Results from the California GAMA program: U.S. Geological Survey Data Series 474, 66 p., http://pubs.usgs.gov/ds/474/.

Gonfiantini, R., 1978, Standards for stable isotope measurements in natural compounds: Nature, v. 271, p. 534-536, http://dx.doi.org/10.1038/271534a0.

Grunsky, C.E., 1907, The lower Colorado River and the Salton Basin: Transactions of the American Society of Civil Engineers, v. 59, p. 1-62.

Guay, B.E., Eastoe, C.J., Bassett, R., and Long, Austin, 2006, Identifying sources of groundwater in the lower Colorado River valley, USA, with $\delta^{18} \mathrm{O}, \delta \mathrm{D}$, and ${ }^{3} \mathrm{H}$ : Implications for river water accounting: Hydrogeology Journal, v. 14, no. 1-2, p. 146-158, http://dx.doi.org/10.1007/s10040-004-0334-4.
Halfman, S.E., Lippmann, M.J., Zelwer, R., and Howard, J.H., 1984, Geologic interpretation of geothermal fluid movement in Cerro Prieto field, Baja California, Mexico: The American Association of Petroleum Geologists Bulletin, v. 68 , no. 1, p. 18-30, http://aapgbull.geoscienceworld.org/ content/68/1/18.abstract.

Hamilton, Warren, 1961, Origin of the Gulf of California: Geological Society of America Bulletin, v. 72, no. 9, p. 1307-1318, http://dx.doi.org/10.1130/00167606(1961)72[1307:OOTGOC]2.0.CO;2.

Hardt, W.F., and French, J.J., 1976, Selected data on water wells, geothermal wells, and oil tests in Imperial Valley, California: U.S. Geological Survey Open-File Report 76-891, 251 p., http://pubs.er.usgs.gov/publication/ofr76891.

Harshbarger, J.W., 1977, Overview report of hydrology and water development, Colorado Delta, United States and Mexico, Preliminary Report PR-235-77-2: Prepared for the International Boundary and Water Commission, United States Section, Tucson, Arizona, 112 p.

Havholm, K.G., and Kocurek, Gary, 1988, A preliminary study of the dynamics of a modern draa, Algodones, southeastern California, USA: Sedimentology, v. 35, no. 4, p. 649-669, http://dx.doi.org/10.1111/j.1365-3091.1988.tb01242.x.

Hely, A.G., 1969, Lower Colorado River water supplyIts magnitude and distribution: U.S. Geological Survey Professional Paper 486-D, 54 p., http://pubs.er.usgs.gov/publication/pp486D.

Hely, A.G., and Peck, E.L., 1964, Precipitation, runoff and water loss in the lower Colorado River-Salton Sea area: U.S. Geological Survey Professional Paper 486-B, 16 p., http://pubs.er.usgs.gov/publication/pp486B.

Hely, A.G., Hughes, G.H., and Irelan, Burdge, 1966, Hydrologic regimen of Salton Sea, California: U.S. Geological Survey Professional Paper 486-C, 32 p., http://pubs.er.usgs.gov/publication/pp486C.

Hill, D.P., Mowinckel, P., and Peake, L.G., 1975, Earthquakes, active faults, and geothermal areas in the Imperial Valley, California: Science, v. 188, no. 4195, p. 1306-1308, https:// nrmsecure.dfg.ca.gov/FileHandler.ashx?DocumentID=8387.

Hinojosa-Huerta, Osvel, Nagler, P.L., CarrilloGuerrero, Yamilett, Zamora-Hernández, Enrique, GarcíaHernández, Jaqueline, Zamora-Arroyo, Francisco, Gillon, Kara, and Glenn, E.P., 2002, Andrade Mesa wetlands of the All-American Canal: Natural Resources Journal, v. 42, no. 4, p. 899-914.

Hubbs, C.L, Bien, G.S., and Suess, H.E., 1963, La Jolla natural radiocarbon measurements III: Radiocarbon, v. 5, p. 254-272, https://journals.uair.arizona.edu/index.php/ radiocarbon/article/download/3391/2983. 
Irelan, B., 1971, Salinity of surface water in the lower Colorado River-Salton Sea area: U.S. Geological Survey Professional Paper 486-E, 39 p., http://pubs.er.usgs.gov/publication/pp486E.

Izbicki, J.A., 2004, A small-diameter sample pump for collection of depth-dependent samples from production wells under pumping conditions: U.S. Geological Survey Fact Sheet 2004-3096, 2 p., http://pubs.usgs.gov/fs/2004/3096/.

Izbicki, J.A., Christensen, A.H., Hanson, R.T., Martin, Peter, Crawford, S.M., and Smith, G.A., 1999, U.S. Geological Survey combined well-bore flow and depth-dependent water sampler: U.S. Geological Survey Fact Sheet 196-99, 2 p., http://pubs.usgs.gov/fs/1999/fs19699/.

James, G.W., 1906, The overflow of the Colorado River and the Salton Sea-II: Scientific American, v. 94, no. 16, p. $328-329$.

Jennings, Scott, and Thompson, G.R., 1986, Diagenesis of plio-pleistocene sediments of the Colorado River delta, southern California: Journal of Sedimentary Petrology, v. 56, no. 1, p. 89-98, http://dx.doi.org/10.1306/212F88912B24-11D7-8648000102C1865D.

Johnson, A.I., 1967, Specific yield: Compilation of specific yields for various materials: U.S. Geological Survey Water Supply Paper 1662-D, 74 p., http://pubs.er.usgs.gov/publication/wsp1662D.

Kalin, R.M., 2000, Radiocarbon dating, in Cook, P.G., and Herczeg, A.L., eds., Environmental tracers in subsurface hydrology: Boston, Mass., Kluwer Academic Publishers, p. 111-144.

Kohler, W.M., and Fuis, G.S., 1986, Travel-time, time-term, and basement depth maps for the Imperial Valley region, California, from explosions: Bulletin of the Seismological Society of America, v. 76, no. 5, p. 1289-1303, http://www.bssaonline.org/content/76/5/1289. short.

Kovach, R.L., Allen, C.R., and Press, Frank, 1962, Geophysical investigations in the Colorado delta region: Journal of Geophysical Research, v. 67, no. 7, p. 28452871, http://dx.doi.org/10.1029/JZ067i007p02845.

LeRoy Crandall and Associates, 1983, Phase 1 hydrogeologic investigation feasibility of recovering ground water in the East Mesa area, Imperial County, California: Prepared for Six Agency Committee, no. E-83066, 62 p.

Lippmann, M.J., Truesdell, A.H., HalfmanDooley, S.E., and Manonm, A., 1991, A review of the hydrogeologic-geochemical model for Cerro Prieto: Geothermics v. 20, no. 1-2, p. 39-52, http://dx.doi.org/10.1016/0375-6505(91)90004-F.
Loeltz, O.J., and Leake, S.A., 1979, Relation between proposed developments of water resources and seepage from the All-American Canal, Eastern Imperial Valley, California: U.S. Geological Survey Open-File Report 79-744, 83 p.

Loeltz, O.J., Irelan, Burdge, Robison, J.H., and Olmstead, F.H., 1975, Geohydrologic reconnaissance of the Imperial Valley, California: U.S. Geological Survey Professional Paper 486-K, 54 p., http://pubs.er.usgs.gov/publication/pp486K.

Longman, I.M., 1959, Formulas for computing the tidal acceleration due to the moon and sun: Journal of Geophysical Research, v. 64, no. 12, p. 2351-2355, http://dx.doi.org/10.1029/JZ064i012p02351.

Lonsdale, Peter, 1989, Geology and tectonic history of the Gulf of California, in Winterer, E.L., Hussong, D.M., and Decher, R.W., eds., The Eastern Pacific Ocean and Hawaii: Boulder, Colorado, Geological Society of America, v. N, p. 499-521, .

Lower Colorado Water Supply Act, 1986, United States Public Law 99-655, 99th Congress, H.R. 5028, November 14, 1986, 100 STAT. 3667, 3p.

Maganda, C., 2005, Collateral damage: How the San Diego-Imperial Valley water agreement affects the Mexican side of the border: The Journal of Environment and Development, v. 14, no. 4, p. 486-506, http://dx.doi.org/10.1177/1070496505282668.

Mathany, T.M, Wright, M.T., Beuttel, B.S., and Belitz, Kenneth, 2012, Groundwater-quality data in the Borrego Valley, Central Desert, and low-use basins of the Mojave and Sonoran Deserts study unit, 20082010 - Results from the California GAMA Program: U.S. Geological Survey Data Series 659, 100 p., http://pubs.usgs.gov/ds/659/.

Mattick, R.E., Olmsted, F.H., and Zohdy, A.A.R., 1973, Geophysical studies in the Yuma area, Arizona and California: U.S. Geological Survey Professional Paper 726 D, 35 p., 5 pls., http://pubs.er.usgs.gov/publication/pp726D.

McCoy, F.W. Jr., Nokleberg, W.J., and Norris, R.M., 1967, Speculations on the origin of the Algodones dunes, California: Geological Society of America Bulletin, v. 78, no. 8, p. 1039-1044, http://dx.doi.org/10.1130/00167606(1967)78[1039:SOTOOT]2.0.CO;2.

McDonald, C.C., and Hughes, G.H., 1968, Studies of consumptive use of water by phreatophytes and hydrophytes near Yuma, Arizona: U.S. Geological Survey Professional Paper 486-F, 24 p., http://pubs.er.usgs.gov/publication/pp486F. 
McDonald, C.C., and Loeltz, O.J., 1976, Water resources of lower Colorado River-Salton Sea area as of 1971; Summary report: U.S. Geological Survey Professional Paper 486-A, 33 p., http://pubs.er.usgs.gov/publication/pp486A.

Meckel, L.D., 1975, Holocene sand bodies in the Colorado Delta area, northern Gulf of California: in Broussard, M.L., ed., Deltas: Models for Exploration: Houston Geological Society, p. 239-265.

Meidav, Tsvi., and Furgerson, R., 1972, Resistivity studies of the Imperial Valley geothermal area, California: Geothermics v. 1, no. 2, p. 47-62, http://dx.doi. org/10.1016/0375-6505(72)90012-0.

Mendenhall, W.C., 1909a, Some desert watering places in southeastern California and southwestern Nevada: U.S. Geological Survey Water Supply Paper 224, 98 p., http://pubs.er.usgs.gov/publication/wsp224.

Mendenhall, W.C., 1909b, Ground waters of the Indio region, California, with a sketch of the Colorado Desert: U.S. Geological Survey Water Supply Paper 225, 56 p., http://pubs.er.usgs.gov/publication/wsp225.

Merriam, Richard, 1969, Source of sand dunes of southeastern California and northwestern Sonora, Mexico: Geological Society of America Bulletin, v. 80, no. 3, p. 531-534, http://dx.doi.org/10.1130/0016-7606(1969)80[531:SOSDO S]2.0.CO;2.

Merriam, Richard, and Bandy, O.L., 1965, Source of upper Cenozoic sediments in Colorado Delta region: Journal of Sedimentary Research, v. 35, no. 4, p. 911-916, http://dx.doi.org/10.1306/74D713A2-2B21-11D78648000102C1865D.

Metzger, D.G., and Loeltz, O.J., 1973, Geohydrology of the Needles area, Arizona, California, and Nevada: U.S. Geological Survey Professional Paper 486-J, 53 p., http://pubs.er.usgs.gov/publication/pp486J.

Metzger, D.G., Loeltz, O.J., and Irelan, Burdge, 1973, Geohydrology of the Parker-Blythe-Cibola area, Arizona and California: U.S. Geological Survey Professional Paper 486-G, 129 p., http://pubs.er.usgs.gov/publication/pp486G.

Michel, R.L., 1976, Tritium inventories of the world oceans and their implications: Nature, v. 263, p. 103-106, http://dx.doi.org/10.1038/263103a0.

Montgomery Watson, Inc., 1996, Imperial County Groundwater Study, Final Report: June, 1996, 248 p.

Mook, W.G., 1980, The dissolution-exchange model for dating of groundwater with ${ }^{14} \mathrm{C}$, in Fritz, P., and Fontes, J.C., eds., Handbook of environmental isotopes geochemistry: Amsterdam, Elsevier Science Publishing Company, v. 1, p. 50-74.
Muffler, L.J.P., and Doe, B.R., 1968, Composition and mean age of detritus of the Colorado River delta in the Salton Trough, southeastern California: Journal of Sedimentary Research, v. 38, no. 2, p. 384-399, http://dx.doi. org/10.1306/74D719A1-2B21-11D7-8648000102C1865D.

National Water Commission of Mexico, 1991, Effects in Mexican territory of lining of the All-American Canal: General Subdirectorate for Water Administration, General Groundwaters Office, Mexico City, included as Attachment D of the 1994 AAC Final EIS/EIR Geohydrology Appendix, $25 \mathrm{p}$.

National Water Commission of Mexico, 2005, Hydrologic effects provoked in Mexican territory by the recovery of infiltrated water in the All-American Canal in California, United States of America: Mexico City, Office of the Assistant Director, Groundwater Management, $14 \mathrm{p}$.

Nielson, Jamie, and Kocurek, Gary, 1986, Climbing zibars of Algodones: Sedimentary Geology, v. 48, no. 1-2, p. 1-15, http://dx.doi.org/10.1016/0037-0738(86)90078-3.

Norris, R.M., and Norris, K.S., 1961, Algodones Dunes of southeastern California: Geological Society of America Bulletin, v. 72, no. 4, p. 605-619, http://dx.doi. org/10.1130/0016-7606(1961)72[605:ADOSC]2.0.CO;2.

Olmstead, F.H., Loeltz, O.J., and Irelan, Burdge, 1973, Geohydrology of the Yuma area, Arizona and California: U.S. Geological Survey Professional Paper 486-H, 226 p., http://pubs.er.usgs.gov/publication/pp486H.

Owen-Joyce, S.J., Wilson, R.P., Carpenter, M.C., and Fink, J.B., 2000, Method to identify wells that yield water that will be replaced by water from the Colorado River downstream from Laguna Dam in Arizona and California: U.S. Geological Survey Water-Resources Investigations Report 2000-4085, 31 p., http://pubs.er.usgs.gov/publication/wri004085.

Pacheco, Martin, Martín-Barajas, Arturo, Elders, Willfred, Espinosa-Cardeña, J.M., Helenes, Javier, and Segura, Alberto, 2006, Stratigraphy and structure of the Altar Basin of NW Sonora: Implications for the history of the Colorado River delta and the Salton trough: Revista Mexicana de Ciencias Geológicas, v. 23, no. 1, p. 1-22, http://www.redalyc.org/pdf/572/57230101.pdf.

Palacky, G.J., 1988, Resistivity characteristics of geologic targets, chap. 3, in Nabighian, M.N., ed., Electromagnetic methods in applied geophysics, Volume 1, Theory: Tulsa, Oklahoma, Society of Exploration Geophysics, p. 52-129, http://dx.doi.org/10.1190/1.9781560802631.ch3.

Parsons, T., and McCarthy, J., 1996, Crustal and upper mantle velocity structure of the Salton Trough, southeast California: Tectonics, v. 15 , no. 2 , p. 456-471. 
Patten, E.P. Jr., 1977, Analog simulation of the groundwater system, Yuma, Arizona: U.S. Geological Survey Professional Paper 486-I, 9 p., https://pubs.er.usgs.gov/publication/pp486I.

Payne, B.R., Quijano, Luis, and Latorre, D.C., 1979, Environmental isotopes in a study of the origin of salinity of groundwater in the Mexicali Valley: Journal of Hydrology, v. 41, no. 3-4, p. 201-215, http://dx.doi.org/10.1016/0022-1694(79)90062-3.

Pool, D.R., and Eychaner, J.H., 1995, Measurements of aquifer-storage change and specific yield using gravity surveys: Groundwater, v. 33, no. 3, p. 425-432, http://dx.doi.org/10.1111/j.1745-6584.1995.tb00299.x.

Portugal, Enrique, Izquierdo, Georgina, Truesdell, Alfred, and Álvarez, Julio, 2005, The geochemistry and isotope hydrology of the southern Mexicali Valley in the area of the Cerro Prieto, Baja California (Mexico) geothermal field: Journal of Hydrology, v. 313, no. 3-4, p. 132-148, http://dx.doi.org/10.1016/j.jhydrol.2005.02.027.

PRISM Climate Group, Oregon State University, 2010, United States average annual precipitation, maximum and minimum temperature, 1940-2009: accessed May 14, 2012, at http://prism.oregonstate.edu/.

Pritt, J.W., and Raese, J.W., 1995, Quality assurance/quality control manual; National Water Quality Laboratory: U.S. Geological Survey Open File Report 95-443, 35 p., http://pubs.er.usgs.gov/publication/ofr95443.

Rex, R.W., Babcock, E.A., Biehler, S., Combs, J., Coplen, T.B., Elders, W.A., Furgerson, R.B., Garfunke, Z., Meidav, T., Robinson, P.T., 1971, Cooperative geologicalgeophysical-geochemical investigations of geothermal resources in the Imperial Valley area of California: University of California, Riverside, $153 \mathrm{p}$.

Robison, J.H., 1965, Environment of the Imperial trough, California, during the Quaternary-A paleogeographic problem [abs]: Geological Society of America Annual Meeting, Cordilleran Section, Fresno, California, p. 47.

Rozanski, Kazimierz, Araguás-Araguás, Luis, and Gonfiantini, Roberto,1993, Isotopic patterns in modern global precipitation, in Swart, P.K., Lohmann, K.C., Mckenzie, J., and Savin, S., eds., Climate change in continental isotopic records: American Geophysical Union, Washington, D.C., http://www.psu.edu/dept/liberalarts/sites/ kennett/pdf/rozanski_1993_GM_global-isotopic-pattern. pdf.

San Luis Rey Indian Water Rights Settlement Act, 1988, United States Public Law 100-675, 102 STAT. 4000, 100th Congress, S. 795, November 17, 1988.
Schroeder, R.A., Setmire, J.G., and Densmore, J.N., 1991, Use of stable isotopes, tritium, soluble salts, and redox-sensitive elements to distinguish ground water from irrigation water in the Salton Sea Basin, in Ritter, W.F., ed., Proceedings of the 1991 National Conference on Irrigation and drainage, American Society of Civil Engineers, Honolulu, Hawaii, U.S.A., July 22-26, 1991, p. 524-530.

Sharp, R.P., 1979, Intradune flats of the Algodones chain, Imperial Valley, California: Geological Society of America Bulletin, v. 90, no. 10, p. 908-916, http://dx.doi. org/10.1130/0016-7606(1979)90<908:IFOTAC>2.0.CO;2.

Smith, G.I., Friedman, Irving, Gleason, J.D., and Warden, Augusta, 1992, Stable isotope composition of waters in southeastern California: 2. Groundwaters and their relation to modern precipitation: Journal of Geophysical Research, v. 97, no. D5, p. 5813-5823, http://dx.doi.org/10.1029/92JD00183.

Smith, R.S.U., Yeend, W.E., Dohrenwend, J.C., and Gese, D.D., 1984, Mineral resources of the north Algodones Dunes wilderness study area (CDCA-360), Imperial County, California: U.S. Geological Survey Open-File Report 84-630, 11 p., http://pubs.er.usgs.gov/publication/ofr84630.

State of California, 2007, Agreement for the creation and delivery of extraordinary conservation intentionally created surplus: Sacramento, California, State of California, dated December 13, 2007.

Stokes, S., Kocurek, G., Pye, K., and Winspear, N.R., 1997, New evidence for the timing of Aeolian sand supply to the Algodones dunefield and East Mesa area, southeastern California, USA: Paleogeography, Paleoclimatology, Paleoecology, v. 128, no. 1-4, p. 63-75, http://dx.doi.org/10.1016/S0031-0182(96)00048-X.

Sweet, M.L., Nielson, Jamie, Havholm, K., and Farrelley, John, 1988, Algodones dune field of southeastern California: Case history of a migrating modern dune field: Sedimentology, v. 35, no. 6, p. 939-952, http://dx.doi.org/10.1111/j.1365-3091.1988.tb01739.x.

Tarbet, L.A., and Holman, W.H., 1944, Stratigraphy and micropaleontology of the west side of the Imperial Valley, California [abs.]: American Association of Petroleum Geologists Bulletin, v. 28, no. 12, p. 1781-1782, http://archives.datapages.com/data/bulletns/1944-48/ images/pg/00280012/1750/17810a.pdf.

Tartakovsky, G.D., and Neuman, S.P., 2007, Threedimensional saturated-unsaturated flow with axial symmetry to a partially penetrating well in a compressible unconfined aquifer: Water Resources Research, v. 43, no. 1, http://dx.doi.org/10.1029/2006WR005153. 
Telford, W.M., Geldart, L.P., and Sheriff, R.E., 1990, Applied Geophysics, 2nd ed.: Cambridge UK, Cambridge University Press, 770 p.

Tetra Tech Inc., 1999, A study on seepage and subsurface inflows to Salton Sea and adjacent wetlands-Final report: Prepared for Salton Sea Authority, no. 10293-09, 135 p.

Thomas, R.G., 1963, The late Pleistocene 150-foot fresh water beach line of the Salton Sea area: Southern California Academy of Sciences Bulletin, v. 62, pl. 1, p. 9-17.

Tompson, Andrew, Demir, Zafer, Moran, Jean, Mason, Denise, Wagoner, Jeff, Kollet, Stefan, Mansoor, Kayyum, and McKereghan, Peter, 2008, Groundwater availability within the Salton Sea Basin, final report: Lawrence Livermore National Laboratory, no. LLNL-TR-400426, 143 p., https://e-reports-ext.1lnl.gov/pdf/356709.pdf.

Umhoefer, P.J., 2011, Why did the Southern Gulf of California rupture so rapidly?-Oblique divergence across hot, weak lithosphere along a tectonically active margin: Geological Survey of America, GSA Today, v. 21, no. 11, p. 4-10, http://dx.doi.org/10.1130/G133A.1.

U.S. Bureau of Reclamation, 1992, Contract among the United States, Imperial Irrigation District, and Coachella Valley Water District for exchange of water from the Lower Colorado Water Supply Project Well Field for Colorado River Water: U.S. Bureau of Reclamation, no. 2-07-30W0277, dated May 22, 1992, 8 p.

U.S. Bureau of Reclamation, 1994, Final environmental impact statement/final environmental impact report-AllAmerican Canal Lining Project: U. S. Department of the Interior, Bureau of Reclamation, Lower Colorado River Region, Imperial Irrigation District, 176 p.

U.S. Bureau of Reclamation, 2004, Quality of project well field water to be exchanged, Amendment 1 to Contract among the United States, Imperial Irrigation District, and Coachella Valley Water District for exchange of water from the Lower Colorado Water Supply Project Well Field for Colorado River Water: U.S. Department of the Interior, Bureau of Reclamation, no. 2-07-30-W0277, dated April 26, 2004, 2 p.

U.S. Bureau of Reclamation, 2006, All-American Canal Lining Project, supplemental information report: U.S. Department of the Interior, Bureau of Reclamation, Lower Colorado River Region, Imperial Irrigation District, $73 \mathrm{p}$.

U.S. Bureau of Reclamation, 2012, Boulder Canyon Project-All-American Canal system: accessed May 14, 2012, at http://www.usbr.gov/projects/Project.jsp?proj_ Name $=$ Boulder $\% 20$ Canyon $\% 20$ Project $\% 20 \% 20-\% 20$ AllAmerican\%20Canal\%20System.
U.S. Geological Survey, variously dated, National field manual for the collection of water-quality data: U.S. Geological Survey Techniques of Water-Resources Investigations, book 9, chaps. A1-A9, http://pubs.water.usgs.gov/twri9A.

Van de Kamp, P.C., 1973, Holocene continental sedimentation in the Salton Sea, California-A reconnaissance: Geological Society of America Bulletin, v. 84, no. 3, p. 827-848, http://dx.doi.org/10.1130/0016-7606(1973)84<827:HCSITS $>2.0 . \mathrm{CO} ; 2$.

Wallace, R.E., ed., 1990, The San Andreas fault system, California: U.S. Geological Survey Professional Paper 1515, 283 p., http://pubs.usgs.gov/pp/1990/1515/.

Waters, M.R., 1983, Late Holocene lacustrine chronology and archaeology of ancient Lake Cahuilla, California: Quaternary Research, v. 19, no. 3, p. 373-387, http://dx.doi.org/10.1016/0033-5894(83)90042-X.

Watt, D., 1994, Final environmental impact statement/ final environmental impact report-All-American Canal Lining Project, Geohydrology Appendix: Prepared for U.S. Department of the Interior, Bureau of Reclamation, Lower Colorado River Region, Imperial Irrigation District, $360 \mathrm{p}$.

Wilke, P.J., 1978, Late prehistoric human ecology at Lake Cahuilla, Coachella Valley, California: Contributions of the University of California Archaeological Research Facility, no. 38,168 p.

Wilson, R.P., and Owen-Joyce, S.J., 1994, Method to identify wells that yield water that will be replaced by Colorado River water in Arizona, California, Nevada, and Utah: U.S. Geological Survey Water-Resources Investigations Report 94-4005, 36 p., http://pubs.er.usgs.gov/publication/wri944005.

Winker, C.D., and Kidwell, S.M., 1986, Paleocurrent evidence for lateral displacement of the Pliocene Colorado River delta by the San Andreas fault system, southeastern California: Geology v. 14, no. 9, p. 788-791.

Winspear, N.R., and Pye, K., 1995, Sand supply to the Algodones dunefield, south-eastern California, USA: Sedimentology, v. 42, no. 6, p. 875-891, http://dx.doi.org/10.1111/j.1365-3091.1995.tb00415.x.

Woerner, L., 1989, The creation of the Salton Sea: An engineering folly: Journal of the West, v. 28, 110 p. 


\section{Appendix 1. Well Construction and Groundwater Elevation Data}

The following tables are supplied in a Microsoft Excel $^{\circledR}$ file.

Table 1-1. Groundwater-elevation network well data and groundwater-elevation data, Imperial Valley, California, 2009-11.

Table 1-2. Groundwater-quality network well data and groundwater-quality and isotope data, Imperial Valley, California, 2007-11.

Table 1-3. Composite and depth-specific groundwater-quality and isotope data for well LCWSP-2, Imperial Valley, California, August 26-27, 2009.

Table 1-4. Gravity in microgals ( $\mu$ gal) at gravity stations, Imperial Valley, California, 2009-11.

Table 1-5. Repeat land-surface elevation measurements at gravity stations, Imperial Valley, California, 2009-10. 


\section{Appendix 2. Gravity Data, Methods, and Interpretation}

New and existing gravity data were compiled, collected, and analyzed from three sources: historical data archived at the GeoNet gravity database (Pan-American Center for Earth and Environmental Studies, 2008), historical data collected by the U.S. Geological Survey (USGS) in support of earlier studies (Owen-Joyce and others, 2000; Dickinson and others, 2006), and data collected by USGS for this study. About 2,950 gravity measurements in the study area form the complete Bouguer anomaly (CBA) dataset analyzed (fig. 2-1). Of these measurements, 2,600 were obtained from the GeoNet database. Many of these data were collected by Kovach and others (1962), and station elevations were determined by survey bench marks and level lines, which were estimated to have 0.3 milligal (mGal) precision. Although further metadata for the GeoNet measurements were largely nonexistent, some consistency checks were undertaken, and data were transformed to the International Geo Sample Number (IGSN) 1971 reference when the data were incorporated into the National Geophysical Data Center Land and Marine Gravity Data compilation (Dater and others, 1999), the primary source of the GeoNet data. Only the measured absolute gravity value and coordinates were used for these stations.

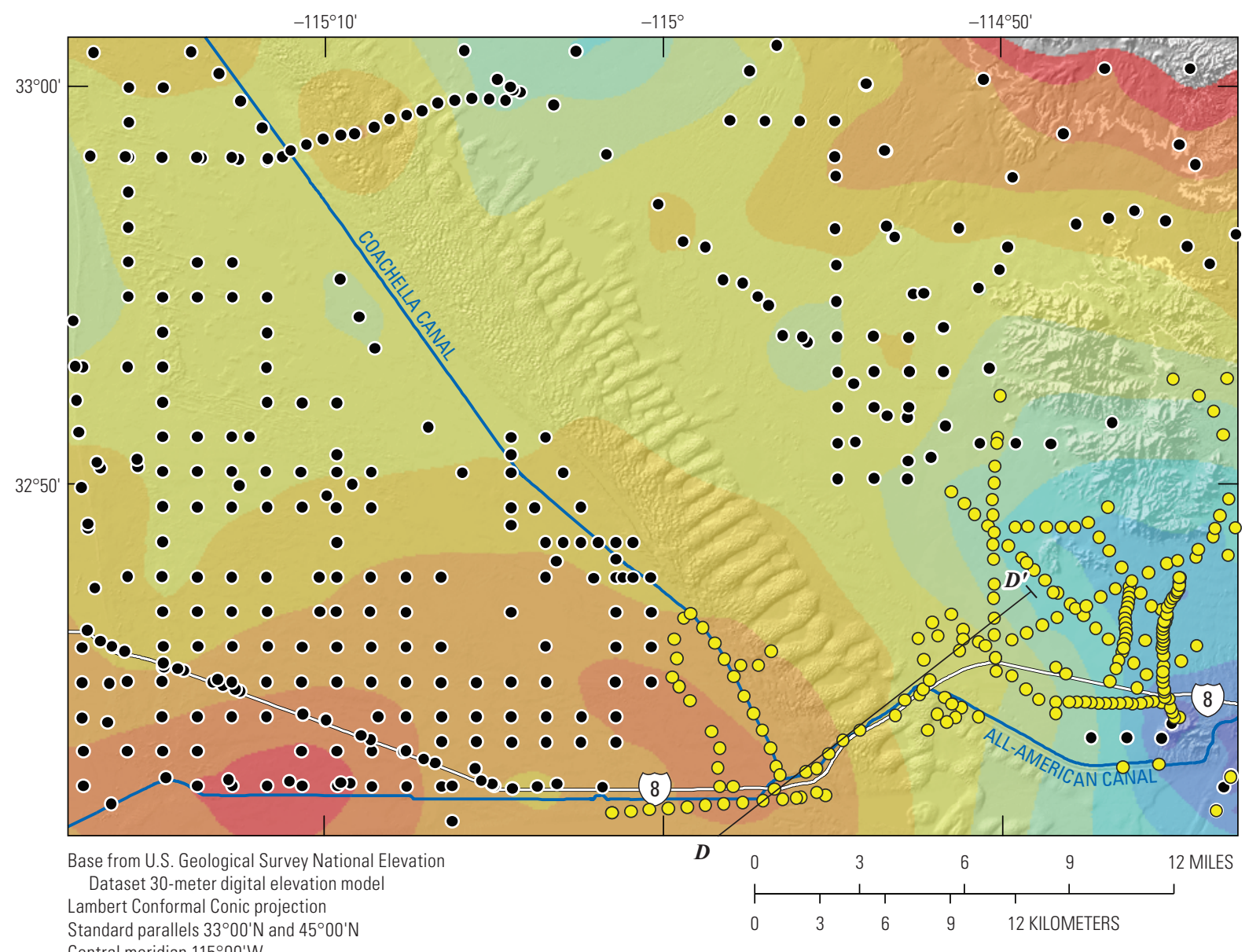

EXPLANATION

Gravity data source

O U.S. Geological Survey

- GeoNet

Complete bouguer anomaly, in milligal

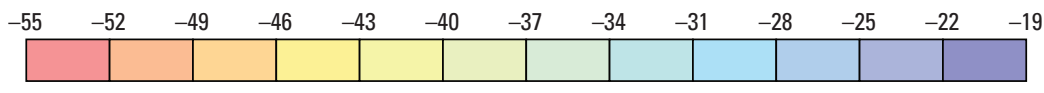

Figure 2-1. Gravity measurement sites, and location of cross section D-D', Imperial Valley, California. 
Gravity surveys in the study area-primarily where the All-American Canal (AAC) crosses the Algodones Duneswere done by USGS in 1997-98 and 2010. For all gravity stations, GeoNet and USGS, corrections were applied as follows (Hinze and others, 2005). Theoretical gravity on the ellipsoid was determined by using the 1980 International Gravity Formula in the Somigliana closed form. The freeair correction was accomplished by using the Heiskanen and Moritz formula. The Bouguer correction, including the Bullard spherical cap correction, was performed assuming an earth radius of $4,182.5$ miles (mi), a crustal density of 2,670 kilograms per cubic meters $\left(\mathrm{kg} / \mathrm{m}^{3}\right)$, and the Newtonian gravitational constant 6.673 times $10^{-11} \mathrm{~m}^{3} \mathrm{~kg}^{-1} \mathrm{~s}^{-2}$ (Hinze and others, 2005). Terrain corrections were calculated to a distance of $93 \mathrm{mi}$ (http://www.geosoft.com). To avoid the indirect effect, in which elevation rather than ellipsoid height is used in gravity reduction, thereby incorporating variation in the geoid in the anomaly (Talwani, 1998), ellipsoid height was used for calculating theoretical gravity, the free-air correction, and the Bouguer correction. Corpscon software (U.S. Army Corps of Engineers, 2010) and GEOID03 were used to convert GeoNet elevations to ellipsoid height. The ellipsoid height of USGS stations was determined directly from Global Positioning Systems (GPS) measurements.

Gravity modeling of the study area was complicated by two factors. First, the Algodones Dunes are largely inaccessible for gravity measurements because of their steep, loose terrain. Second, there is lateral and vertical heterogeneity in the deep crust and mantle below the Salton Trough. These must be adequately modeled and removed to accurately represent the gravity anomaly caused by the nearsurface sedimentary units. Several seismic studies (Fuis and others, 1984; Parsons and McCarthy, 1996; Tape and others, 2009) have recognized crustal thinning in the study area, with a zone of high mantle material underlying the trough. The gravitational effect of this high-density elevated mantle partially compensates the low-density sedimentary material. Furthermore, evidence indicated lateral variation in seismic velocity and, therefore, variation in density in the deep crust and mantle between the trough and the Chocolate Mountains (Parsons and McCarthy, 1996). Fortunately, the extent of this thinning and the density of the raised mantle have been relatively well-defined by previous studies, and the resultant gravitational effect was incorporated into the gravity model.

A three-dimensional, four-layer gravity model was constructed to simulate sediment thickness (figs. 2-1, 2-2). The upper layer was assigned densities determined by Kovach and others (1962) on the basis of an analysis of samples from well drilling: 2.37 grams per cubic centimeters $\left(\mathrm{g} / \mathrm{cm}^{3}\right)$ for the interval from the surface to 4,000 feet $(\mathrm{ft}) ; 2.44 \mathrm{~g} / \mathrm{cm}^{3}$ from 4,000 ft to $8,000 \mathrm{ft}$; and $2.47 \mathrm{~g} / \mathrm{cm}^{3}$ below $8,000 \mathrm{ft}$. The second layer from the top is non-sedimentary basement rock and was assigned a density of $2.75 \mathrm{~g} / \mathrm{cm}^{3}$ after Fuis and others (1984). Below this is a sub-basement layer having a of density $2.95 \mathrm{~g} / \mathrm{cm}^{3}$. It varies in depth from $10 \mathrm{mi}$ below land surface in the southwest part of the model area to $17 \mathrm{mi}$ below land surface in the extreme northeast and varies in thickness from $4 \mathrm{mi}$ in the southwest to $0 \mathrm{mi}$ in the northeast. Below this is a mantle layer, the top of which also dips to the northeast. Density in the mantle varies laterally from $3.2 \mathrm{~g} / \mathrm{cm}^{3}$ in the southwest to $3.3 \mathrm{~g} / \mathrm{cm}^{3}$ in the northeast, based on velocities from the Pacific to Arizona Crustal Experiment (Parsons and McCarthy, 1996). The complete Bouguer anomaly continues upward from the land surface to 4,265 ft elevation. Although this filtered some short-wave-length features, given the lack of gravity data for the dunes area in the center of the model area, where subtle features would be most expected, the effect was not severe. The position of the interface between the bottom of sedimentary material and the top of basement rock was solved through iterative forward modeling (http://www.geosoft.com). A constant offset was introduced so that sediment thickness was near-zero in areas of exposed bedrock in the Cargo Muchacho Mountains.

Three-dimensional gravity modeling indicated sedimentary deposits in the study area gradually increasing in thickness from bedrock outcrops at the Cargo Muchacho Mountains and Pilot Knob to the east toward bedrock lows to the west (fig. 2-2). The thickest sediments are in the southwestern portion of the study area and were estimated to be about 16,000-ft-thick, which is in agreement with previous depth-to-basement estimates from seismic data (Kohler and Fuis, 1986).

In the area where the AAC crosses the Algodones Dunes, sediment thickness was estimated to be between 5,000 ft and $10,000 \mathrm{ft}$ (fig. 2-2). Although the general trend is toward a more negative gravity anomaly and, therefore, thicker sediment to the southwest, a normal fault to the west of the Algodones Dunes with approximately 4,000 ft displacement is indicated by an area of steeper gradient in the gravity cross section in the vicinity of Drop 1 and the Coachella Canal (fig. 2-2). A fault in this area corresponds with the southeast projection of the Sand Hills fault, previously mapped to the north of the study area (Meidav and Furgerson, 1972; Fuis and others, 1984; Parsons and McCarthy, 1996; California Geological Survey, 2010). The broad area over which this region of steeper gradient extends (about 5 miles in fig. 2-2), indicates that the density contrast causing it is relatively deep and precludes large density contrasts and, therefore, faulting in the shallow subsurface.

In comparison, a relatively steep gravity gradient to the east of the Algodones Dunes indicates basement faulting at a depth of about 2,500 feet about halfway between LCWSP Well 2 and the Cargo Muchacho Mountains, which approximately corresponds with the northwest projection of the Algodones fault to the southeast (Mattick and others, 1973; Fuis and others, 1984; Parsons and McCarthy, 1996; California Geological Survey, 2010).

Gravity-data inversion is inherently non-unique, and many geologically reasonable models could fit the observed gravity data equally well. Previous resistivity profiles and electrical soundings (Olmstead and others, 1973) and magnetic surveys and very-low-frequency surveys (Dickinson and 
$\boldsymbol{A}$

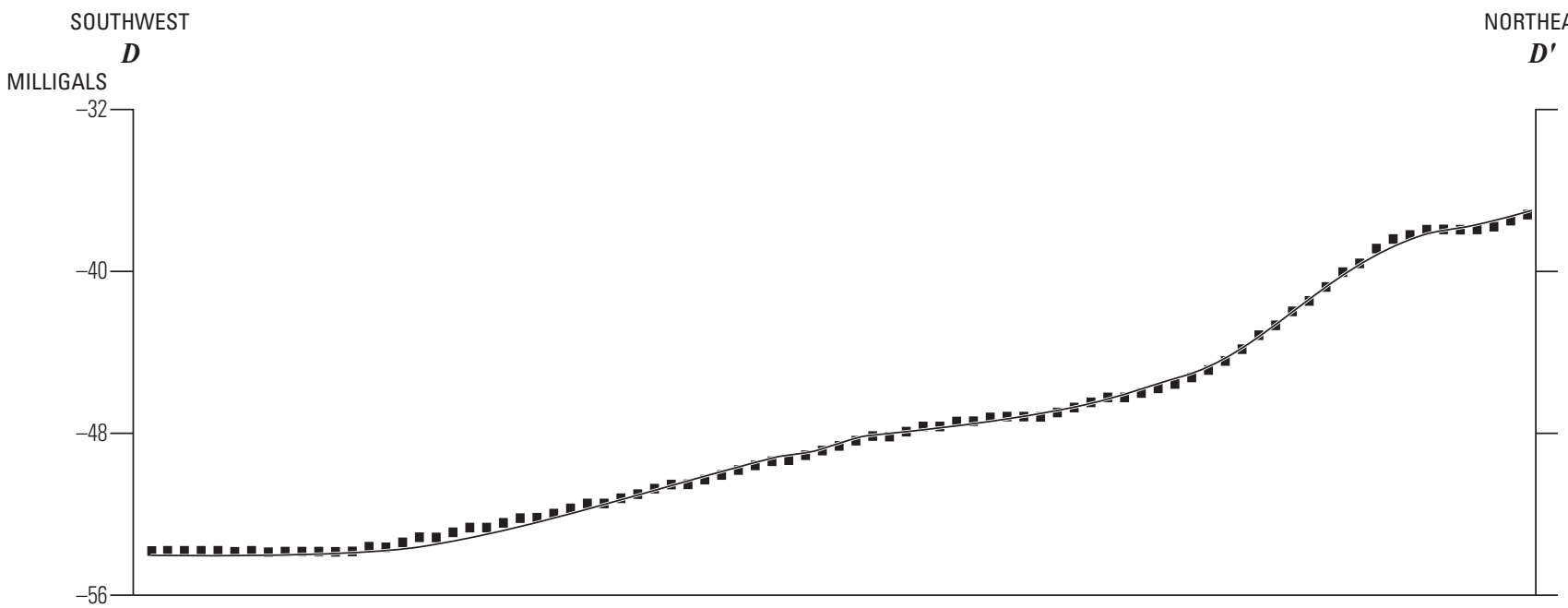

$\boldsymbol{B}$
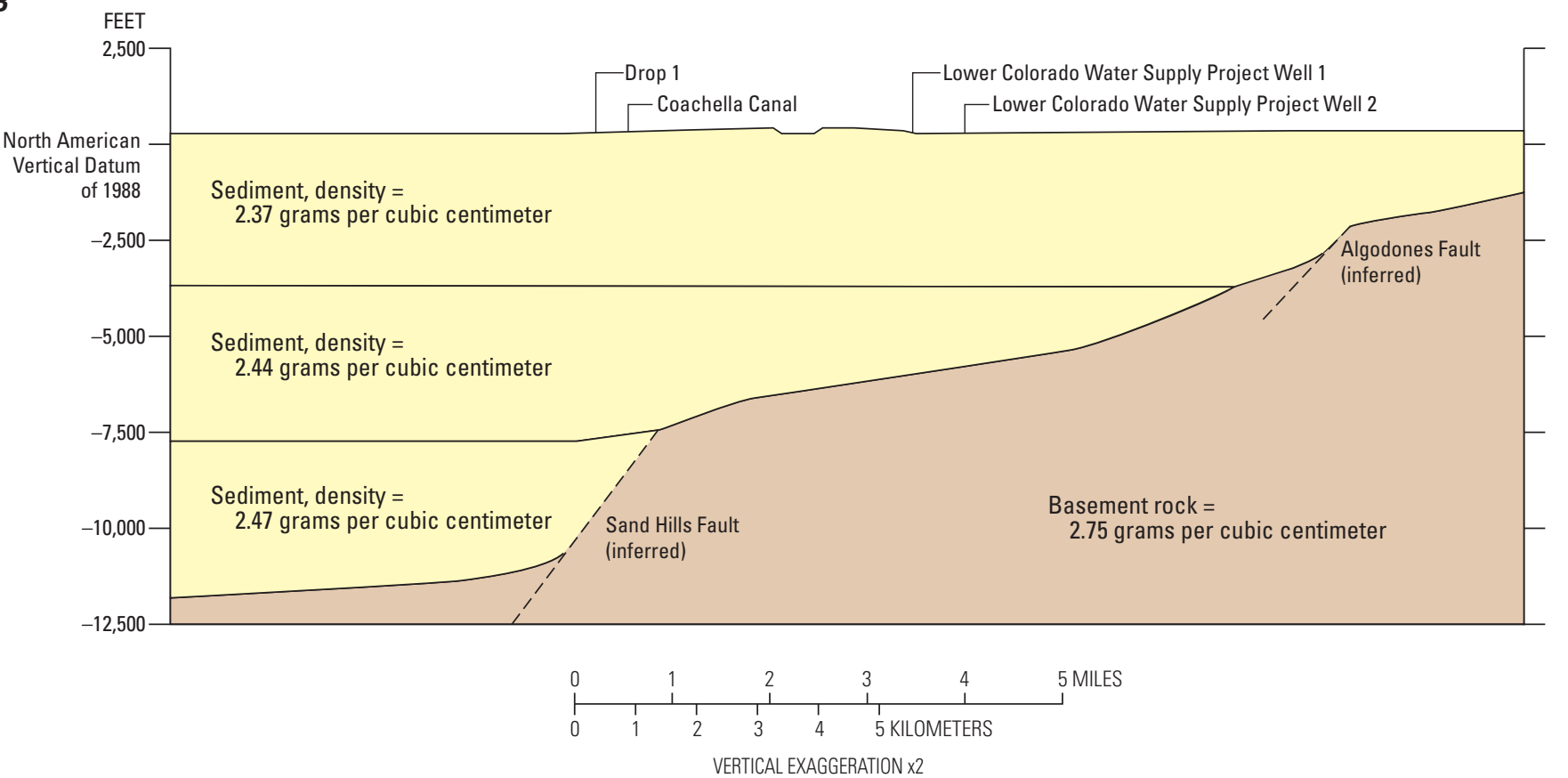

\section{EXPLANATION}

- . - . - . - Gravity profile interpolated from the complete Bouguer anomaly

Predicted gravity profile for the cross-section shown

Figure 2-2. Cross sections showing: $A$, measured and predicted gravity anomaly along transect D-D; $B$, subsurface density model along transect D-D', Imperial Valley, California.

others, 2006) failed to conclusively identify the Algodones fault in the study area. Previous seismic work (Fuis and others, 1984) indicated subtle changes in the slope of the contact between sedimentary material and basement coincided with mapped locations of the Sand Hills and Algodones faults, but no obvious fault-related offset was apparent from the data. Nonetheless, gravity data indicated two areas of relatively steep gravity change where the Sand Hills and Algodones faults were projected to cross the AAC. Based on the magnitude and spatial extent of the observed gravity change, the Sand Hills fault likely crosses in the vicinity of Drop 1 at a depth of about $10,000 \mathrm{ft}$, whereas the Algodones fault is about 4 miles northeast of the Algodones Dunes, midway between the dunes and the Cargo Muchacho Mountains. 


\section{References Cited}

California Geological Survey, 2010, 2010 Fault Activity Map of California: California Geological Survey Geologic Data Map No. 6, http://www.quake.ca.gov/gmaps/FAM/ faultactivitymap.html.

Dater, D., Metzger, D., and Hittelman, A., 1999, Land and marine gravity CD-ROMs: Gravity 1999 edition on 2 CD-ROMs: National Geophysical Data Center, Boulder, Colorado.

Dickinson, J.E., Land, Michael, Faunt, C.C., Leake, S.A., Reichard, E.G., Fleming, J.B., and Pool, D.R., 2006, Hydrogeologic framework refinement, ground-water flow and storage, water-chemistry analyses, and water-budget components of the Yuma area, southwestern Arizona and southeastern California: U.S. Geological Survey Scientific Investigations Report 2006-5135, 88 p., http://pubs.usgs.gov/sir/2006/5135/.

Fuis, G.S., Mooney, W.D., Healy, J.H., McMechan, G.A., and Lutter, W.J., 1984, A seismic refraction survey of the Imperial Valley region, California: Journal of Geophysical Research, v. 89, no. B2, 1165-1189, http://dx.doi.org/10.1029/JB089iB02p01165.

Hinze, W.J., Aiken, Carlos, Brozena, John, Coakley, Bernard, Dater, David, Flanagan, Guy, Forsberg, Rene, Hildenbrand, Thomas, Keller, G.R., Kellogg, J.N., Kucks, Robert, Li, Xiong, Mainville, Andre, Morin, Robert, Pilkington, Mark, Plouff, Donald, Ravat, Dhananjay, Roman, Daniel, Urrutia-Fucugauchi, Jamie,

Véronneau, Marc, Webring, Michael, and Winester, Daniel, 2005, New standards for reducing gravity data-The North American gravity database: Geophysics, v. 70, no. 4, p. J25-J32, http://dx.doi.org/10.1190/1.1988183.

Kohler, W.M., and Fuis, G.S., 1986, Travel-time, time-term, and basement depth maps for the Imperial Valley region, California, from explosions: Bulletin of the Seismological Society of America, v. 76, no. 5, p. 1289-1303, http://www.bssaonline.org/content/76/5/1289.abstract.

Kovach, R.L., Allen, C.R., and Press, Frank, 1962, Geophysical investigations in the Colorado delta region: Journal of Geophysical Research, v. 67, no. 7, p. 28452871, http://dx.doi.org/10.1029/JZ067i007p02845.
Mattick, R.E., Olmsted, F.H., and Zohdy, A.A.R., 1973, Geophysical Studies in the Yuma Area, Arizona and California: U.S. Geological Survey Professional Paper 726 D, 35 p., 5 pls., http://pubs.er.usgs.gov/publication/pp726D.

Meidav, T., and Furgerson, R., 1972, Resistivity studies of the Imperial Valley geothermal area, California: Geothermics v. 1, no. 2, p. 47-62, http://dx.doi.org/10.1016/0375-6505(72)90012-0.

Olmstead, F.H., Loeltz, O.J., and Irelan, Burdge, 1973, Geohydrology of the Yuma area, Arizona and California: U.S. Geological Survey Professional Paper 486-H, 226 p., http://pubs.er.usgs.gov/publication/pp486H.

Owen-Joyce, S.M., Wilson, R.P., Carpenter, M.C., and Fink, J.B., 2000, Method to identify wells that yield water that will be replaced by water from the Colorado River downstream from Laguna Dam in Arizona and California: U.S. Geological Survey Water-Resources Investigations Report 00-4085, 31 p., http://pubs.er.usgs. gov/publication/wri004085.

Pan-American Center for Earth and Environmental Studies, 2008, Geonet gravity and magnetic dataset repository: Pan-American Center for Earth and Environmental Studies, accessed July 20, 2010, at http://irpsrvgis08.utep. edu/viewers/Flex/GravityMagnetic/GravityMagnetic CyberShare/.

Parsons, T., and McCarthy, J., 1996, Crustal and upper mantle velocity structure of the Salton Trough, southeast California: Tectonics, v. 15, no. 2, p. 456-471.

Talwani, Manik, 1998, Errors in the total Bouguer reduction: Geophysics, v. 63, p. 1125-1130, http://dx.doi.org/10.1190/1.1444412.

Tape, C., Liu, Q., Maggi, A., and Tromp, J., 2009, Adjoint tomography of the southern California Crust: Science, v. 325, no. 5943, p. 988-992, http://dx.doi.org/10.1126/science.1175298.

U.S. Army Corps of Engineers, 2010, Corpscon Version 6.0, accessed at http://www.agc.army.mil/Missions/Corpscon. aspx. 


\section{Appendix 3. Water-Quality Assurance Plan and Water-Quality Control Data}

Quality-assurance procedures were followed to minimize the potential for bias and variability in the environmental data during water-quality sample collection and analysis. Design of the quality-assurance plan and quality-control sample collection was based on requirements described in the National Field Manual for the Collection of Water-Quality Data (U.S. Geological Survey, variously dated). One field blank sample was collected to assess bias, and one replicate sample was collected to assess variability, for the major ions and trace elements of interest.

The field-blank sample was collected subsequent to collection of the environmental samples and cleaning of the sampling equipment by passing water free of the constituents of interest through the sampling equipment. This sample was analyzed to determine if bias existed in the data from contamination during sample collection or analysis. Calcium, boron, and manganese were detected in the field blank at concentrations of 0.03 milligrams per liter $(\mathrm{mg} / \mathrm{L})$, 3.4 micrograms per liter $(\mu \mathrm{g} / \mathrm{L})$, and $1.2 \mu \mathrm{g} / \mathrm{L}$, respectively. All of the environmental samples had concentrations of calcium and boron at least three times greater than the blank concentrations; these constituents were not considered to have been affected by contamination, and the data for these constituents were not censored. Manganese concentrations in environmental samples were censored below $3.6 \mu \mathrm{g} / \mathrm{L}$ (three times the measured field-blank concentration).

The replicate sample was obtained by sequentially collecting an additional sample from the same site and for the same constituents as the environmental sample. Data from this sample provided an estimate of the variability that resulted from the combined efforts of field and laboratory procedures. The differences between all of the paired samples of major ions, trace elements, and stable isotopes were less than 5 percent (with maximum percentage difference of 3.5 percent), which was an acceptable range of variability for this study.

The USGS National Water Quality Laboratory (NWQL) maintains an internal program that includes the use of data from blank, replicate, and spike samples to ensure that the laboratory is accurately analyzing water-quality samples (Pritt and Raese, 1995). The Quality-Assurance Unit of the NWQL routinely submits blind reference samples and blank samples to the NWQL. The USGS Branch of Quality Systems, which operates independently of the NWQL, also submits blind reference samples to the NWQL. The NWQL reporting levels are based upon this quality-control data and are reviewed annually and updated as needed.

\section{References Cited}

Pritt, J.W., and Raese, J.W., 1995, Quality assurance/ quality control manual: U.S. Geological Survey Open-File Report 95-443, 35 p., http://pubs.er.usgs.gov/publication/ofr95443.

U.S. Geological Survey, variously dated, National field manual for the collection of water-quality data: U.S. Geological Survey Techniques of Water-Resources Investigations, book 9, chaps. A1-A9, http://pubs.water.usgs.gov/twri9A. 

Publishing support provided by the U.S. Geological Survey Science Publishing Network, Sacramento, Publishing Service Center

For more information concerning the research in this report, contact the Director, California Water Science Center U.S. Geological Survey 6000 J Street, Placer Hall Sacramento, California 95819 


\section{递}

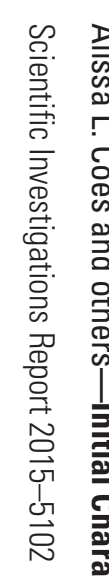

